\title{
Japan: Insurance Core Principles-Detailed Assessment of Observance
}

This paper was prepared based on the information available at the time it was completed in August, 2012. The views expressed in this document are those of the staff team and do not necessarily reflect the views of the government of Japan or the Executive Board of the IMF.

The policy of publication of staff reports and other documents by the IMF allows for the deletion of market-sensitive information.

Copies of this report are available to the public from

International Monetary Fund • Publication Services

$70019^{\text {th }}$ Street, N.W. • Washington, D.C. 20431

Telephone: (202) 623-7430 • Telefax: (202) 623-7201

E-mail: publications@imf.org Internet: http://www.imf.org

\section{International Monetary Fund Washington, D.C.}


FinANCIAL SECTOR ASSESSMENT PROGRAM

\title{
JAPAN
}

\section{INSURANCE CORE PRINCIPLES}

\section{DETAILED ASSESSMENT OF OBSERVANCE}

\author{
August 2012
}


Glossary

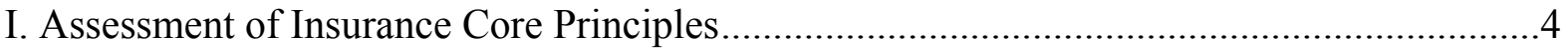

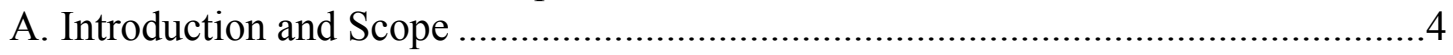

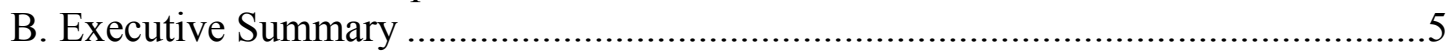

C. Institutional and Market Structure-Overview ..................................................6

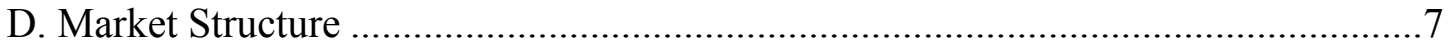

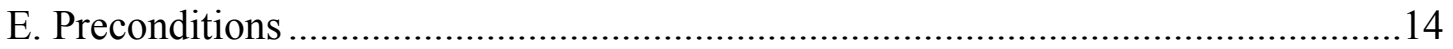

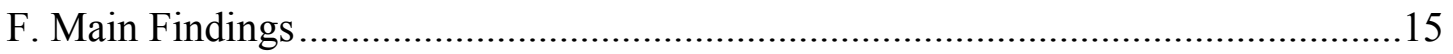

G. Recommendations and the Authorities' Responses ...........................................29

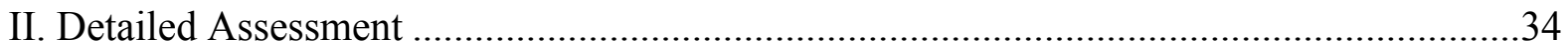

Tables

1. Financial Assets of the Financial System, end-2010 ................................................... 7

2. Selected Indicators of Ten Largest Insurance Markets, 2010 .......................................8

3. Numbers of Life Insurers and Nonlife Insurers, FY 2004-2010 ...................................9

4. Market Share of Top Insurers as Percentages of Premiums ............................................. 9

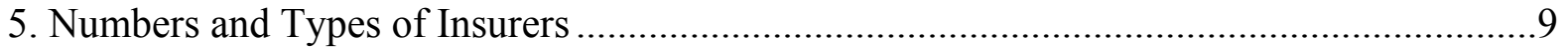

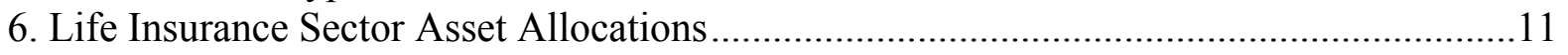

7. Nonlife Insurance Sector Asset Allocations ................................................................ 11

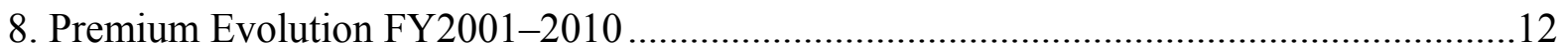

9. Direct Net Premiums for Nonlife Lines of Business ................................................... 13

10. Estimated Loss from the Great East Japan Earthquake ..............................................14

11. Overview of Past Bankruptcy Procedures .............................................................. 17

12. Solvency Margins of Life Insurers ............................................................................ 19

13. Deterioration of Combined Ratio for Nonlife Insurance ..............................................20

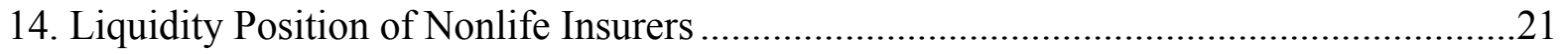

15. Sufficiency of the Technical Reserves of Nonlife Insurers, end-FY2011 .....................22

16. Risk Ratio Development for Nonlife Insurers ......................................................22

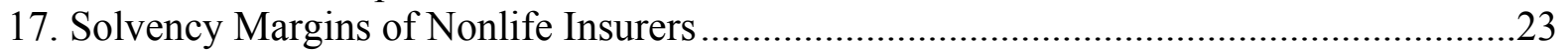

18. Summary of Observance of the Insurance Core Principles ...........................................23

19. Recommendations to Improve Observance of ICPs .....................................................29

20. Detailed Assessment of Observance of the Insurance Core Principles ............................34

Figures

1. Life Insurance New Business During FY2010 .......................................................13

2. Profit of Life Insurance Sector, FY2010 ................................................................. 18

3. Negative Spread Between Assumed Interest Rate and Investment Return .......................18

4. Profit of the Nonlife Insurance Sector, FY2010 ........................................................20 


\section{GLOSSARY}

IBA

FSA

FY

GAAP

IAIS

ICP

JGB

LEFSA

MMoU

$\mathrm{MoU}$

OEIBA

QIS

JPY

J-SOX
Insurance Business Act

Financial Services Agency

Fiscal year (12 months, beginning April 1 of the specified year)

Generally accepted accounting principles

International Association of Insurance Supervisors

Insurance Core Principles

Japanese government bonds

Law on the Establishment of the Financial Services Agency

Multilateral Memorandum of Understanding

Memorandum of Understanding

Order for the Enforcement of the Insurance Business Act

Qualitative Impact Study

Japanese yen

Japan Sarbanes Oxley-like requirements 


\section{ASSESSMENT OF INSURANCE CORE PRINCIPLES}

\section{A. Introduction and Scope}

1. This report is a full assessment of Japan's compliance with the Insurance Core Principles (ICPs) of the International Association of Insurance Supervisors (IAIS), as adopted in October 2011. The review was carried out as part of the 2011 Financial Sector Assessment Program (FSAP) assessment of Japan, and was based on the regulatory framework in place, the supervisory practices employed, and other conditions as they existed in December 2011. The assessment was carried out by Mr. Rodolfo Wehrhahn, Technical Assistance Advisor, in the Financial Sector Oversight Division, a part of the Monetary and Capital Markets Department, IMF, and Mr. Michael Hafeman, Insurance and Pensions Expert; and with support provided by Mr. W. Raphael Lam, a part of the Asian and Pacific Department, IMF.

2. Regulation and supervision of the insurance industry in Japan is largely the responsibility of the Financial Services Agency (FSA). The FSA is an external organ of the Cabinet Office, headed by a Commissioner, and accountable to the Minister for Financial Services.

3. The assessment is based solely on the laws, regulations, and other supervisory requirements and practices that were in place at the time of assessment. Ongoing regulatory initiatives are noted by way of additional comments. Assessors had access to a complete self-assessment on the ICPs and responses to a detailed questionnaire that had been provided by the FSA prior to the commencement of the exercise.

4. The assessment has been informed by discussions with regulators and market participants. The assessors met with staff from the FSA and various government ministries, insurers, industry associations, professional bodies and firms, and rating agencies. The assessors are grateful for the full cooperation extended by all.

5. Japan is the first jurisdiction to be assessed under the 2011 version of the ICPs. The efforts required by the FSA to prepare the self-assessment, even while final changes to the ICPs were being deliberated, as well as its excellent support during the mission, are especially appreciated.

6. The level of observance for each ICP reflects the assessment of the various standards thereunder. Each ICP is rated in terms of the level of observance as follows:

- Observed - whenever all the standards are considered to be observed or when all the standards are observed except for a number that are considered not applicable.

- Not Applicable — when the standards are considered to be not applicable.

- $\quad$ Largely Observed - where only minor shortcomings exist, which do not raise any concerns about the authorities' ability to achieve full observance. 
- $\quad$ Partly Observed - where, despite progress, the shortcomings are sufficient to raise doubts about the authorities' ability to achieve observance.

- Not Observed - where no substantive progress toward observance has been achieved.

\section{B. Executive Summary}

7. Low interest rates and declining equity prices have placed considerable pressure on the insurance market, influencing both its structure and regulation. The failures of seven mid-size companies in the late 1990s and early 2000s resulted in mergers and acquisitions, creating larger players but also opening the market for more foreign participants. The 2010 mega mergers marked another milestone in the streamlining of the market. As a result, in the nonlife sector three groups control over 90 percent of the market and four companies over 65 percent of the life market, excluding the Japan Post Insurance (JPI). Regulatory valuation and solvency requirements were revised to include elements that allow for a long term recovery of deficits. Rules governing the winding up of companies also allow for the amendment of existing contracts, for example, in the form of a lower guaranteed interest rate.

8. The FSA has been strengthening its insurance regulatory framework, including the solvency requirements applicable to insurers and insurance holding companies. The FSA should build on this by completing the development of a methodology for risk-rating insurers, adopting a structured system for the internal review of risk assessments, and further increasing the level of resources to enable inspections to be performed more frequentlyparticularly for the largest insurers. Participation of the industry in the financing of the FSA, through legally-enforceable levies, could be useful in strengthening both its resources and its independence.

9. Corporate governance has made improvements but the corporate governance and suitability requirements should be revised to strengthen independent oversight. This would support the supervisory efforts of the FSA.

10. The FSA requires insurers to take steps to deal with identified weaknesses, but its intervention efforts could be enhanced. The FSA should make greater use of the tools available to it, such as the power to impose fines on insurers and intermediaries, to develop a more progressive approach to enforcement.

11. Exposure to natural catastrophes makes strong reinsurance coverage essential to the Japanese insurance market and overall economy. The regulation and supervision of reinsurance should be strengthened, for example, through measures such as stronger documentation requirements, more complete disclosure of insurers' exposures to their major reinsurers, and a more formal assessment of the manner in which foreign reinsurers are supervised. 
12. In addition to the strengthening of solvency margin requirements, the FSA is taking other steps to enhance the solvency of insurers. It is emphasizing the importance of enterprise risk management and is considering the adoption of a more economic-based valuation regime, to take fuller account of emerging experience and expected future experience. Efforts in such areas should continue.

\section{The FSA has developed a good foundation for dealing with group-wide and} macroprudential issues, but more could be done. Steps have been taken to enhance the supervision of Japanese insurance holding companies, cooperation with foreign supervisors, and market analysis capabilities. The FSA should continue to improve its ability to anticipate and deal with crisis situations by taking steps to maximize the value of its macroprudential analyses, developing contingency plans, and cooperating more proactively with foreign supervisors - including through the establishment of colleges of supervisors for Japanese insurance groups, as highlighted in the recent revisions of the ICPs.

\section{Institutional and Market Structure-Overview}

\section{Institutional structure}

\section{The Law on the Establishment of the Financial Services Agency (LEFSA)} defines the FSA as the authority generally responsible for supervision of the insurance business. The Insurance Business Act (IBA), the primary legislation through which the insurance business is regulated, identifies some insurance activities as being outside its scope and therefore not supervised by the FSA. They include captives and business transacted by certain closed groups such as labor unions with their members, neither of which is subject to supervision. They also include insurance activities that are subject to other acts; the insurance activities of cooperatives (Kyosai) are subject to other acts and are supervised by the government ministries responsible for the relevant sectors. For example, the insurance activities of agricultural cooperatives are regulated by the Agricultural Cooperatives Act and supervised by the Ministry of Agriculture, Forestry, and Fisheries. The legislation related to the insurance activities of cooperatives (Kyosai) is similar to the IBA and the various ministries communicate with the FSA on policy matters. However, this assessment focuses on the insurance activities that are regulated by the IBA and supervised by the FSA.

\section{The FSA is an external organ of the Cabinet Office, headed by a Commissioner} and accountable to the Minister for Financial Services. Its organization is governed by the Law on the Establishment of the Cabinet Office. The FSA is structured on a functional basis, with three Bureaus: (i) Planning and Coordination; (ii) Inspection; and (iii) Supervisory.

16. JPI is supervised by a dedicated unit within the FSA. The particularities of JPI, like the government guarantee on the old block of business as well as belonging to a stateowned holding company, should not prevent its thorough and consistent supervision and inspection. The assignment of a unit to exclusively supervise the JPI is a valid approach, but 
consistency with the FSA's supervision of other insurers should be secured through the regular exchange of supervisors or peer reviews. Further, the frequency of the inspections should be increased to reflect the relevance of the institution within the financial system.

17. The insurance activity of cooperatives is supervised by various ministries. As a consolidated supervisor, the FSA has been able to use economies of scale; however the large insurance sector served by cooperatives is supervised by independent departments within several ministries. The cooperatives do not belong to the policyholder protection programs.

\section{Market Structure}

18. The insurance industry in Japan is an important part of the financial sector. At the end of 2010, the total assets of the insurance sector amounted to 78 percent of GDP or $¥ 373$ trillion. The life sector has assets of around $¥ 291$ trillion, of which $¥ 96$ trillion correspond to JPI; $¥ 46$ trillion relates to the Zenkyoren, which is the largest federation of cooperatives; and JPY 36 trillion to the nonlife sector.

Table 1. Japan: Financial Assets of the Financial System, end-2010

\begin{tabular}{|c|c|c|c|}
\hline & In yen & $\%$ of GDP & $\%$ of Tota \\
\hline All Financial Institutions & 2,787 & 582 & 100 \\
\hline Bank of Japan & 136 & 28 & 5 \\
\hline Depository corporations & 1,528 & 319 & 55 \\
\hline Banks & 1,520 & 317 & 55 \\
\hline Collectively managed trusts & 8 & 2 & 0 \\
\hline Insurance Funds & 373 & 78 & 13 \\
\hline Life Insurance & 291 & 61 & 10 \\
\hline Nonlife Insurance & 36 & 8 & 1 \\
\hline Mutual Aid Insurance & 46 & 10 & 2 \\
\hline Pension Funds & 122 & 25 & 4 \\
\hline Corporate Pension Funds & 106 & 22 & 4 \\
\hline Other Pension Funds & 16 & 3 & 1 \\
\hline Other Financial Intermediaries and Auxiliaries & 628 & 131 & 23 \\
\hline Investment Trusts & 87 & 18 & 3 \\
\hline Bond Investment Trusts & 13 & 3 & 0 \\
\hline Stock Investment Trusts & 74 & 15 & 3 \\
\hline Finance Companies & 59 & 12 & 2 \\
\hline Structured-Fin. Spec Purp. Cos/Trusts & 24 & 5 & 1 \\
\hline Public Financial Institutions & 317 & 66 & 11 \\
\hline Fiscal Loan Fund & 175 & 37 & 6 \\
\hline Gov't Financial Institutions & 143 & 30 & 5 \\
\hline Financial Dealers \& Brokers & 127 & 27 & 5 \\
\hline Financial Auxiliaries & 13 & 3 & 0 \\
\hline \multicolumn{4}{|l|}{ Memorandum item: } \\
\hline GDP & 479 & & \\
\hline
\end{tabular}

Note: The insurance activities of cooperatives are shown as Mutual Aid Insurance. 
19. In terms of aggregate insurance premiums, Japan is the second largest market in the world, with a share of 13 percent. The total life insurance premium income at the end of the Japanese fiscal year 2010 amounted to $¥ 34$ trillion, or around 17.5 percent of the global life insurance premium, second only to the U.S. The nonlife premium reached $¥ 7.5$ trillion, or around 6.5 percent of the global nonlife insurance premium, sharing the second position with Germany. The Japanese insurance industry employs 2.7 million people_-including sales people.

Error! Bookmark not defined.Table 2. Japan: Selected Indicators of Ten Largest Insurance Markets, 2010

\begin{tabular}{|c|c|c|c|c|c|c|c|}
\hline & \multicolumn{3}{|c|}{ Aggregate Premiums } & \multicolumn{2}{|c|}{ Penetration } & \multicolumn{2}{|l|}{ Density } \\
\hline & USD mn & Rank & $\begin{array}{c}\text { Market } \\
\text { share in } \\
\text { percent }\end{array}$ & $\begin{array}{l}\text { in percent } \\
\text { of GDP }\end{array}$ & Rank & $\begin{array}{l}\text { Premium per } \\
\text { capita (USD) }\end{array}$ & Rank \\
\hline United States & $1,166,142$ & 1 & 26.9 & 8.0 & 18 & $3,758.9$ & 12 \\
\hline Japan & 557,439 & 2 & 12.9 & 10.1 & 8 & $4,390.2$ & 6 \\
\hline United Kingdom & 310,022 & 3 & 7.2 & 12.4 & 3 & $4,496.6$ & 5 \\
\hline France & 280,082 & 4 & 6.5 & 10.5 & 7 & $4,186.6$ & 8 \\
\hline Germany & 239,817 & 5 & 5.5 & 7.2 & 21 & $2,903.8$ & 18 \\
\hline China & 214,626 & 6 & 5.0 & 3.8 & 39 & 158.4 & 61 \\
\hline Italy & 174,347 & 7 & 4.0 & 8.1 & 17 & $2,766.1$ & 20 \\
\hline Canada & 115,521 & 8 & 2.7 & 7.3 & 19 & $3,408.7$ & 15 \\
\hline South Korea & 114,422 & 9 & 2.6 & 11.2 & 6 & $2,339.4$ & 23 \\
\hline Netherlands & 97,057 & 10 & 2.2 & 12.4 & 4 & $5,845.3$ & 2 \\
\hline
\end{tabular}

Sources: Swiss Re sigma No.2/2011-World Insurance in 2010.

20. The sector is highly concentrated. The Japanese life insurance market consists of only 47 companies, as compared with 875 in the United States, around 190 in the United Kingdom, and 231 in France. Only 52 insurers operate in the Japanese nonlife sector, compared to 3,441 in the United States, 790 in the United Kingdom, and 259 in France. JPI accounts for 21 percent of the life premium and the next four largest life insurers for another 43 percent. The five largest nonlife insurers, belonging to three insurance groups, account for 82 percent of the nonlife premium.

21. Foreign insurers are present as branches, subsidiaries, and representative offices and are active in all lines of business. About one-half of the insurers operating in the Japanese insurance market are now foreign-owned. The preferred operating form in the life sector is through a subsidiary, and through a branch in the nonlife area. Foreign-owned companies have a 20 percent market share in the life sector and a less than 10 percent share in the nonlife sector. 
Table 3. Japan: Numbers of Life Insurers and Nonlife Insurers, FY 2004-2010 FY2004 FY2005 FY2006 FY2007 FY2008 FY2009 FY2010

\begin{tabular}{lrrrrrrr}
\hline Life Insurers & 0 & 0 & 0 & 4 & 4 & 2 & 0 \\
$\quad$ Entries & 1 & 1 & 0 & 0 & 0 & 1 & 0 \\
Exits & 39 & 38 & 38 & 42 & 46 & 47 & 47 \\
$\quad$ Total (end of fiscal year) & & & & & & & \\
Nonlife insurers & 1 & 1 & 1 & 5 & 0 & 2 & 3 \\
$\quad$ Entries & 5 & 2 & 1 & 1 & 1 & 2 & 2 \\
$\quad$ Exits & 49 & 48 & 48 & 52 & 51 & 51 & 52 \\
$\quad$ Total (end of fiscal year) & & & & & & & \\
\hline
\end{tabular}

Source: FSA.

Table 4. Japan: Market Share of Top Insurers as Percentages of Premiums

\begin{tabular}{lccc}
\hline Year & 2001 & 2006 & 2010 \\
\hline Life Insurers & & & \\
Top 5 & 61.9 & 54.1 & 64.5 \\
Top 10 & 80.9 & 70.5 & 78.2 \\
Nonlife Insurers & & & \\
Top 5 & 62.7 & 79.1 & 81.7 \\
Top 10 & 80.9 & 94.6 & 93.9 \\
\hline
\end{tabular}

Source: FSA.

Note: Premiums represents gross premiums written for life insurers and direct net premiums for nonlife insurers.

Table 5. Japan: Numbers and Types of Insurers

\begin{tabular}{lcc}
\hline & Life Insurers & Nonlife Insurers \\
\hline Locally incorporated and owned 1/ 2/ & 29 & 24 \\
Locally incorporated, some or all foreign & 14 & 5 \\
ownership & & 22 \\
Branches or agents of foreign insurers 3/ & 4 & 51 \\
Total & 47 & \\
\hline 1/ Includes five mutual companies and one government-controlled company. \\
2/ Includes two reinsurance-only companies. \\
3/ Includes five reinsurance-only companies and three P\&I Clubs (protection and indemnity \\
marine cover).
\end{tabular}

Sources: Life Insurance Association of Japan, as of February 2011 and General Insurance Association of Japan, as of October 1, 2010. 
22. JPI, created in $\mathbf{2 0 0 7}$, is the largest life insurer in the world. Its assets as of March 2011 amounted to $¥ 96.7$ trillion, down from $¥ 100.9$ trillion in the previous fiscal year. Over 65 percent of the assets are invested in government fixed-interest securities and the rest are loans to and receivables from local governments and policyholders. The investment yield in 2011 was 1.64 percent. FY2010 profit after taxes was $¥ 77$ billion, a 10 percent increase from the previous year. The sources of the profit were mortality and expenses gains, which more than offset the negative spread from past interest guarantees. The products are largely traditional life or fixed-term annuities. JPI is not allowed to sell new types of products and thus is excluded from participating in the growing "third sector" business, which includes products such as private medical, hospitalization, disability, cancer and long-term care insurance. Premium income in FY2010 of $¥ 7,342$ billion was around 2 percent lower than in the previous year, and was generated by over $¥ 6$ million individual policies.

\section{There are also 6, 921 cooperatives, whose services include life and nonlife}

insurance. The Japan Cooperative Insurance Association has 14 full members and one associate member, the largest of which is Zenkyoren, the National Mutual Insurance Federation of Agricultural Cooperatives, with $¥ 46$ trillion in assets at the end-March 2011. Around 90 percent of these assets are held in government bonds. Twenty-six million policies on long-term saving products, including both life and nonlife insurance, are in force, accounting for $¥ 311$ trillion insured amount, and another 26 million policies in short-term nonlife insurance produce $¥ 344$ billion premium income.

\section{Life insurers managed investments in the order of JPY 320 trillion in 2010 and} are significant holders of Japan government bonds (JGB). The long-term character of life insurance liabilities drives an investment mix of around 70 percent in government bonds. The incorporation of JPI has raised the amount of JGB holdings by the industry from $¥ 48$ trillion at the end of 2007 to $¥ 118$ trillion in 2008 . Currently the industry holds $¥ 132$ trillion in government bonds. On the other hand, risk capital charges and the poor performance of the Japanese stock market resulted in a reduction in equity investments from JPY 32 trillion in 2007 , to a current amount of $¥ 16$ trillion. Loans to corporations remain over 13 percent of total investments.

25. The assets of nonlife insurers have a strong local equity market allocation. The long-standing practice of securing clients through shareholdings resulted in large investments in local equities, which reached a peak in 2003 of over 30 percent of the investments. Recognition of the volatility risk of equities, as well as the declining market, has led nonlife insurers to reduce their equity holdings. Currently around 20 percent of nonlife assets remain in Japanese equities. This share of the investment mix is still about twice that observed in other major international nonlife markets. 
Table 6. Japan: Life Insurance Sector Asset Allocations

(In trillions of yen)

\begin{tabular}{|c|c|c|c|c|c|c|c|c|c|c|c|c|c|c|}
\hline & \multirow{2}{*}{$\begin{array}{c}\text { Cash } \\
\text { and } \\
\text { deposits }\end{array}$} & \multirow{2}{*}{$\begin{array}{l}\text { Call- } \\
\text { Loans }\end{array}$} & \multirow{2}{*}{$\begin{array}{l}\text { Monetary } \\
\text { claims }\end{array}$} & \multirow{2}{*}{$\begin{array}{l}\text { Money } \\
\text { Trusts }\end{array}$} & \multicolumn{6}{|c|}{ Securities } & \multirow[t]{2}{*}{ Loans } & \multirow{2}{*}{$\begin{array}{l}\text { Tangible } \\
\text { fixed } \\
\text { assets 1/ }\end{array}$} & \multirow{2}{*}{$\begin{array}{l}\text { Other } \\
\text { assets }\end{array}$} & \multirow{2}{*}{$\begin{array}{l}\text { Total } \\
\text { assets }\end{array}$} \\
\hline & & & & & $\begin{array}{l}\text { Government } \\
\text { bonds }\end{array}$ & $\begin{array}{l}\text { Local gov. } \\
\text { bonds }\end{array}$ & $\begin{array}{l}\text { Corporate } \\
\text { Bonds }\end{array}$ & Stocks & $\begin{array}{l}\text { Foreign } \\
\text { Securities }\end{array}$ & $\begin{array}{c}\text { Other } \\
\text { Securities }\end{array}$ & & & & \\
\hline$\overline{F Y 2001}$ & 2.9 & 3.4 & 2.9 & 3.6 & 32.8 & 7.2 & 17.9 & 24.7 & 26.4 & 2.0 & 47.1 & 8.1 & 5.4 & 184.4 \\
\hline FY2002 & 2.5 & 2.9 & 2.8 & 3.4 & 34.8 & 7.3 & 19.2 & 17.2 & 29.0 & 2.9 & 44.5 & 7.7 & 5.7 & 179.8 \\
\hline FY2003 & 2.1 & 2.8 & 2.8 & 2.5 & 35.5 & 6.3 & 18.9 & 21.4 & 33.8 & 4.6 & 41.7 & 7.7 & 4.2 & 184.3 \\
\hline FY2004 & 2.1 & 2.2 & 3.5 & 2.0 & 41.9 & 5.9 & 18.3 & 22.1 & 36.5 & 7.2 & 38.4 & 7.4 & 4.1 & 191.5 \\
\hline FY2005 & 3.3 & 2.2 & 3.6 & 2.7 & 44.8 & 5.6 & 18.3 & 30.9 & 39.4 & 11.8 & 36.7 & 6.9 & 3.7 & 209.9 \\
\hline FY2006 & 3.0 & 2.7 & 4.1 & 2.7 & 48.7 & 5.6 & 19.1 & 32.4 & 41.4 & 14.9 & 35.1 & 6.7 & 3.9 & 220.2 \\
\hline FY2007 & 4.7 & 2.9 & 4.6 & 4.6 & 118.7 & 9.1 & 29.8 & 23.9 & 44.1 & 15.2 & 54.1 & 6.7 & 7.9 & 326.4 \\
\hline FY2008 & 5.0 & 2.8 & 3.4 & 2.6 & 123.9 & 9.8 & 27.5 & 15.6 & 40.0 & 13.4 & 51.1 & 6.7 & 9.9 & 311.7 \\
\hline FY2009 & 5.0 & 2.1 & 3.2 & 2.2 & 128.0 & 11.0 & 26.5 & 18.7 & 43.0 & 17.1 & 46.9 & 6.8 & 8.0 & 318.4 \\
\hline FY2010 & 5.7 & 2.0 & 3.0 & 2.1 & 132.4 & 11.9 & 25.3 & 16.2 & 45.7 & 16.4 & 43.9 & 6.8 & 9.3 & 320.7 \\
\hline
\end{tabular}

Source: FSA

1/ For FY2001-2005, it includes real estate and movables.

Table 7. Japan: Nonlife Insurance Sector Asset Allocations

(In trillions of yen)

\begin{tabular}{|c|c|c|c|c|c|c|c|c|c|c|c|c|c|c|}
\hline & \multirow{2}{*}{$\begin{array}{l}\text { Cash } \\
\text { and } \\
\text { deposits }\end{array}$} & \multirow{2}{*}{$\begin{array}{l}\text { Call- } \\
\text { Loans }\end{array}$} & \multirow{2}{*}{$\begin{array}{c}\text { Monetary } \\
\text { claims }\end{array}$} & \multirow{2}{*}{$\begin{array}{l}\text { Money } \\
\text { Trusts }\end{array}$} & \multicolumn{6}{|c|}{ Securities } & \multirow[t]{2}{*}{ Loans } & \multirow{2}{*}{$\begin{array}{l}\text { Tangible } \\
\text { fixed } \\
\text { assets }\end{array}$} & \multirow{2}{*}{$\begin{array}{l}\text { Other } \\
\text { assets }\end{array}$} & \multirow{2}{*}{$\begin{array}{l}\text { Total } \\
\text { assets }\end{array}$} \\
\hline & & & & & $\begin{array}{l}\text { Government } \\
\text { bonds }\end{array}$ & $\begin{array}{l}\text { Local gov. } \\
\text { bonds }\end{array}$ & $\begin{array}{l}\text { Corporate } \\
\text { Bonds }\end{array}$ & Stocks & $\begin{array}{l}\text { Foreign } \\
\text { Securities }\end{array}$ & $\begin{array}{c}\text { Other } \\
\text { Securities }\end{array}$ & & & & \\
\hline$\overline{\text { FY2001 }}$ & 2.3 & 0.6 & 0.3 & 0.4 & 1.9 & 1.5 & 5.0 & 10.0 & 4.3 & 0.5 & 4.4 & 2.0 & 4.0 & 37.2 \\
\hline FY2002 & 1.7 & 0.6 & 0.2 & 0.3 & 2.9 & 1.2 & 4.3 & 6.8 & 4.0 & 0.5 & 3.4 & 1.6 & 3.2 & 30.7 \\
\hline FY2003 & 1.6 & 0.8 & 0.2 & 0.2 & 3.7 & 1.0 & 4.1 & 9.1 & 4.0 & 0.6 & 3.1 & 1.5 & 2.4 & 32.5 \\
\hline FY2004 & 1.2 & 0.3 & 0.6 & 0.2 & 4.7 & 0.8 & 4.0 & 9.1 & 4.6 & 0.7 & 2.9 & 1.4 & 2.4 & 33.0 \\
\hline FY2005 & 1.1 & 0.3 & 0.9 & 0.3 & 4.9 & 0.8 & 4.1 & 12.8 & 4.9 & 0.9 & 2.7 & 1.3 & 2.2 & 37.1 \\
\hline FY2006 & 1.0 & 0.6 & 1.3 & 0.3 & 4.6 & 0.7 & 4.2 & 12.9 & 5.1 & 0.9 & 2.6 & 1.3 & 2.2 & 37.8 \\
\hline FY2007 & 1.0 & 0.6 & 1.7 & 0.2 & 4.8 & 0.7 & 4.3 & 9.5 & 5.4 & 0.7 & 2.6 & 1.2 & 2.6 & 35.2 \\
\hline FY2008 & 1.0 & 0.6 & 0.4 & 0.1 & 4.5 & 0.7 & 4.0 & 6.2 & 4.9 & 0.5 & 2.6 & 1.2 & 3.8 & 30.4 \\
\hline FY2009 & 1.0 & 0.3 & 1.3 & 0.1 & 5.1 & 0.6 & 3.9 & 7.5 & 5.0 & 0.4 & 2.4 & 1.2 & 3.1 & 32.0 \\
\hline FY2010 & 1.0 & 0.8 & 0.9 & 0.1 & 5.2 & 0.5 & 3.4 & 6.5 & 4.8 & 0.3 & 2.2 & 1.2 & 3.3 & 30.2 \\
\hline
\end{tabular}

Source: FSA

\section{Premiums in both the life and nonlife sectors have stagnated in recent years.}

Nonlife premiums have been declining in the past decade, due in part to a significant decline in production of return-of-premium products ${ }^{1}$, which began losing their attractiveness due to low interest guarantees. Life premiums have been flat for the last decade. The decline in saving and mortality protection products with the aging population has been offset by growth

\footnotetext{
${ }^{1}$ A traditional part of the nonlife market consists of long-term, return-of-premium policies, which combine insurance protection with savings.
} 
in health related and living benefits products like hospitalization, cancer, and long term care insurance. The 2008 premium increment in the life sector reflects the incorporation of Japan Post Insurance into the statistics.

Table 8. Japan: Premium Evolution FY2001-2010

(In trillions of yen)

\begin{tabular}{lrr} 
& \multicolumn{1}{c}{$\begin{array}{c}\text { Life } \\
\text { insurance }\end{array}$} & $\begin{array}{c}\text { Nonlife } \\
\text { insurance }\end{array}$ \\
\hline FY2001 & 26.2 & 8.5 \\
FY2002 & 25.5 & 7.9 \\
FY2003 & 26.0 & 7.9 \\
FY2004 & 27.0 & 7.8 \\
FY2005 & 28.3 & 8.0 \\
FY2006 & 27.8 & 8.1 \\
FY2007 & 30.9 & 8.0 \\
FY2008 & 34.1 & 7.8 \\
FY2009 & 34.1 & 7.7 \\
FY2010 & 34.5 & 7.5 \\
\hline
\end{tabular}

Source: FSA.

Note: Premiums represents gross premiums written for life insurers and direct net premiums for nonlife insurers.

\section{Life products are mainly traditional individual endowments, whole life, and}

term insurance. The large sales force of agents dominates as a distribution channel, and focuses mainly on simple life protection and saving products, which account for 87 percent of the sales. Financial institutions, particularly banks, distribute saving products, including variable annuities, and are now distributing around 13 percent of the individual life products. Every third policy sold in 2010 was related to the "third sector," which includes products such as private medical, hospitalization, disability, cancer and long-term care insurance.

28. The nonlife sector is dominated by motor insurance. Voluntary and mandatory motor insurance together account for 64 percent of the market, down from 68 percent in 2002. Fire insurance follows, with a 17 percent share. All other types of nonlife insurance are offered. Here again, the main distribution channels are the large sales forces controlled by the insurers. Brokers play a minor role, placing less than 5 percent of the premium. International reinsurance ceded in the fiscal year 2010 was $¥ 310$ billion and inwards reinsurance was $¥ 200$ billion, about the same level as in the previous three years. 
Figure 1. Japan: Life Insurance New Business During FY2010

(In number of policies)

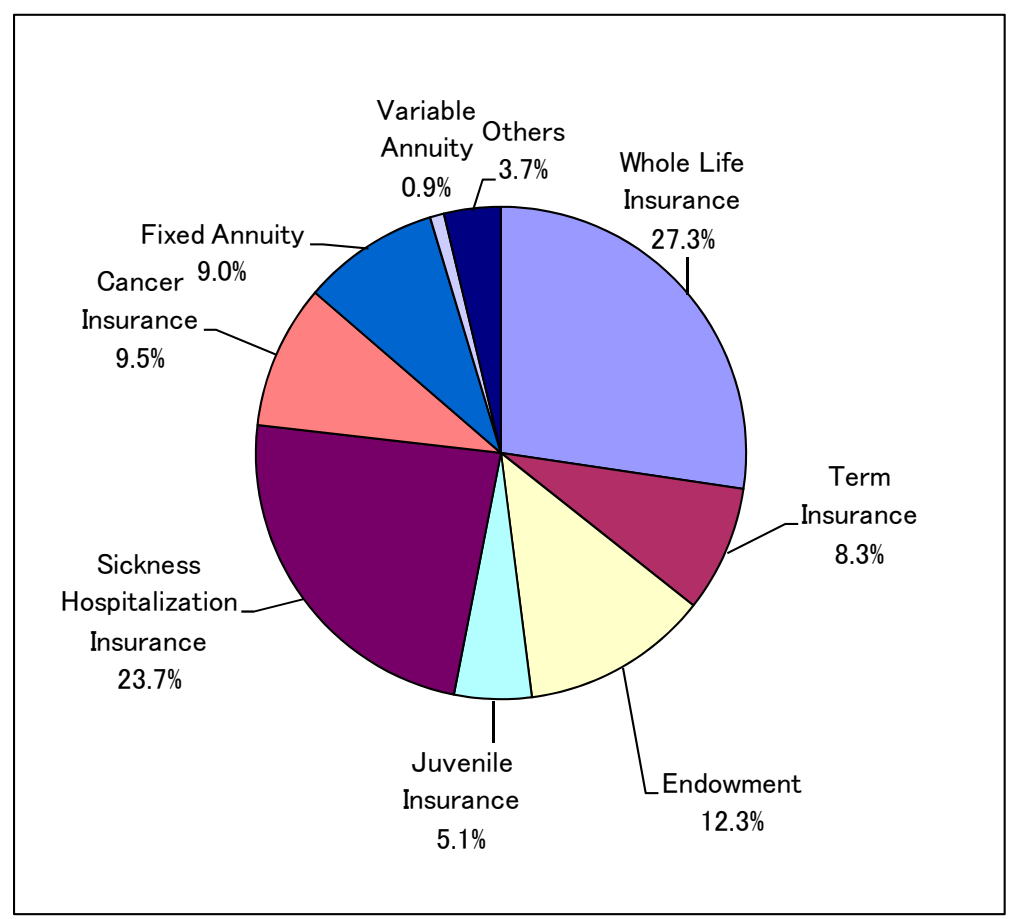

Source: Life Insurance Association of Japan.

Table 9. Japan: Direct Net Premiums for Nonlife Lines of Business

(In trillions of yen)

\begin{tabular}{|c|c|c|c|c|c|c|c|}
\hline & Fire & Marine & $\begin{array}{l}\text { Motor } \\
\text { vehicle }\end{array}$ & $\begin{array}{l}\text { Personal } \\
\text { accident }\end{array}$ & $\begin{array}{l}\text { General } \\
\text { liability }\end{array}$ & $\begin{array}{l}\text { Compulsory } \\
\text { auto policy }\end{array}$ & Others \\
\hline FY2001 & 1.22 & 0.20 & 4.10 & 0.87 & 0.40 & 1.12 & 0.60 \\
\hline FY2002 & 1.12 & 0.19 & 3.70 & 0.80 & 0.36 & 1.19 & 0.52 \\
\hline FY2003 & 1.16 & 0.20 & 3.68 & 0.80 & 0.39 & 1.21 & 0.50 \\
\hline FY2004 & 1.14 & 0.21 & 3.54 & 0.81 & 0.41 & 1.16 & 0.50 \\
\hline FY2005 & 1.23 & 0.22 & 3.64 & 0.86 & 0.43 & 1.15 & 0.50 \\
\hline FY2006 & 1.24 & 0.24 & 3.66 & 0.86 & 0.47 & 1.14 & 0.46 \\
\hline FY2007 & 1.21 & 0.26 & 3.64 & 0.85 & 0.48 & 1.05 & 0.52 \\
\hline FY2008 & 1.23 & 0.24 & 3.59 & 0.83 & 0.48 & 0.87 & 0.55 \\
\hline FY2009 & 1.23 & 0.19 & 3.56 & 0.82 & 0.51 & 0.81 & 0.55 \\
\hline FY2010 & 1.15 & 0.20 & 3.49 & 0.82 & 0.50 & 0.79 & 0.52 \\
\hline
\end{tabular}

Source: FSA.

29. The insurance sector responded positively to the Great East Japan Earthquake. Both life and nonlife insurers, as well as the cooperative insurers, set up disaster response headquarters within hours of the earthquake. Large numbers of agents and company 
employees were deployed to the affected area, providing support in claims identification and payment. The earthquake exclusion clause was waived and, with the agreement of the FSA, the formal requirements for payment were relaxed. Close collaboration with the police allowed for fast settlement of life benefits and the simple form of the standard earthquake policy covering residential properties allowed for 80 percent of the claims to be paid within 10 weeks. As of September 2011, the homeowners' earthquake insurance had paid $¥ 1,145$ billion in benefits. Most of the claims were covered by the government coinsurance, but a total claim amount of $¥ 367$ billion was retained by the private insurers for the residential insurance, with $¥ 200$ billion of retained claims in the commercial lines. In addition, Zenkyoren, the National Mutual Insurance Federation of Agriculture Cooperatives, indicated that the amount paid and reserved for claims related to the earthquake is in the order of $¥ 780$ billion.

Table 10. Japan: Estimated Loss from the Great East Japan Earthquake

\begin{tabular}{lrc}
\multicolumn{3}{c}{ (In billions of yen) } \\
\hline Company & Residential & Commercial \\
\hline Tokio Marine Nichido & 130.3 & 81.9 \\
MS\&AD Insurance Group & & \\
$\quad$ Mitsui Sumitomo & 71.8 & 43.1 \\
$\quad$ Aioi Nissay Dowa & 59.2 & 19.4 \\
NKSJ Group & & \\
$\quad$ Sompon Japan & 63.4 & 38.5 \\
$\quad$ Nipponkoa & 42.3 & 19.4 \\
Total of five major insurers & $\mathbf{3 6 7 . 0}$ & $\mathbf{2 0 2 . 3}$ \\
\hline Source: Fitch. &
\end{tabular}

\section{E. Preconditions}

30. The Japanese legal system is a blend of civil law with an overlay of common law concepts and traditions, primarily American, that were introduced after World War II. The sources of law include the Constitution, which is the supreme law of the land, and five codes based on the German and French codes of the nineteenth century: the Civil Code, the Commercial Code, the Civil Procedure Code, the Criminal Code, and the Criminal Procedure Code. In addition, today there are hundreds of other pieces of primary legislation and significant bodies of case law to interpret or fill in gaps. The Constitution establishes three separate branches of government. The bicameral Diet is the law-making body. The court system is made up of the Supreme Court as the highest court, several appellate courts, and numerous inferior courts. The executive power is vested in the Cabinet.

31. Japan has financial stability arrangements, outside crisis periods. Two agencies, the Bank of Japan (BOJ) and the FSA, work closely together in support of financial stability, an objective which is incorporated within their respective policy mandates. 
32. Japan has a well-developed financial reporting framework. It includes accounting, auditing, and actuarial standards, professional bodies that support the practitioners and administer discipline programs, and an audit regulator, the Certified Public Accountants and Auditors Oversight Board (CPAAOB), which is connected to the FSA. There are sufficient professionals to support the needs of the insurance sector.

\section{F. Main Findings}

\section{Regulatory and supervisory key findings}

33. The FSA has been strengthening its insurance regulatory framework, including the solvency requirements applicable to insurers and insurance holding companies. It has revised the risk parameters, resulting in an increase in required capital, has extended the solvency requirements to the holding company level and is improving the tools used for supervisory assessment, including stress testing. The FSA should build on this by completing the development of a methodology for risk-rating insurers, adopting a structured system for the internal review of risk assessments, and further increasing the level of resources to enable inspections to be performed more frequently_ particularly for the largest insurers.

34. The FSA has developed a good foundation for dealing with group-wide and macroprudential issues, including the supervision of Japanese insurance holding companies, cooperation with foreign supervisors, and market analysis capabilities. The FSA should continue to improve its ability to anticipate and deal with crisis situations by taking steps to maximize the value of its macroprudential analyses, developing contingency plans, and cooperating more proactively with foreign supervisors - including through the establishment of colleges of supervisors for Japanese insurance groups, as highlighted in the recent revisions of the ICPs.

35. While currently there are no indications of political interference in the supervision of insurers, the legal framework governing the FSA contains elements that could undermine the independence and capacity of the supervisor. For example, the annual budget of the FSA must be approved by the Diet, after first being approved by the Minister for Financial Services and the Ministry of Finance. In recent years, the budget and staffing levels of the FSA have been increasing, while those of other government departments have been reduced. Nevertheless, the budget approved by the Diet has sometimes been less than requested by the FSA. Financing the FSA in a manner that does not involve negotiation of its budget, such as through legally-enforceable levies, could be useful in strengthening both its independence and its resources.

36. The FSA requires insurers to take steps to deal with identified weaknesses, but its intervention efforts could be enhanced. The FSA prefers to deal with minor regulatory violations through dialogue and moral suasion. Minor sanctions are not being applied. At the same time, the formal supervisory administrative action threshold appears to be high, based on the limited number of such actions taken in the last 10 years. The FSA should make 
greater use of the tools available to it, such as the power to impose fines on insurers and intermediaries, to develop a more progressive approach to enforcement.

37. Solvency assessment should be based on a transparent economic valuation of assets and liabilities, which takes into account future cash flows over the full time horizon. The current methods of valuing insurance liabilities do not meet these criteria, which creates the risk that liabilities are not being fully recognized. The FSA should revise its valuation approach to take fuller account of emerging experience and anticipated future experience.

38. Corporate governance has made improvements but independence remains weak. While a few insurers have a board structure with a clear segregation between board members and senior management in place, the majority of the insurers and insurance holding companies maintain the traditional structure of a board largely comprised of senior management overseen by an audit board. However, the board of corporate auditors has limited powers; for example, it cannot dismiss directors or call for a shareholders meeting, which could compromise the timeliness and effectiveness of its interventions. Its work is largely performed by full-time members who were previously part of management, and fit and proper requirements under the IBA do not apply to corporate auditors and apply only to a limited extent to part-time directors. The corporate governance and suitability requirements should be revised to strengthen independent oversight, which will reinforce the supervisory efforts of the FSA.

39. Exposure to natural catastrophes makes strong reinsurance coverage essential to the Japanese insurance market and overall economy. The FSA reviews the reinsurance strategies and programs of insurers, but the regulation and supervision of reinsurance could be strengthened. The FSA should consider measures such as stronger documentation requirements (including the prohibition of side letters) and a more formal assessment of the manner in which foreign reinsurers are supervised. The exclusion of the cooperatives' insurance programs from the national earthquake pool might be reconsidered, as it could affect the solvency of those cooperatives in case of a major event or the failure of reinsurers.

40. Stress testing is at an early stage of use and sophistication. The FSA performs topdown stress testing of the insurance sector each quarter with respect to equity-price, exchange-rate, and credit risks. Insurers are expected to perform stress tests and they generally submit the results of such tests to the FSA. However, the FSA does not prescribe specific stress scenarios that insurers are required to test.

\section{Market key findings}

41. The low interest rate environment plus a declining equity market have shaped the insurance market, creating more efficient players and influencing regulation. The major events occurred in the late 1990s and early 2000s, but restructuring of the market continues. Failure of seven mid-size companies resulted in mergers and acquisitions, creating 
larger players but also opening the market for more foreign participants. The 2010 mega mergers marked another milestone in the streamlining of the market. As a result, in the nonlife sector three groups control over 90 percent of the market and four companies over 65 percent of the life market excluding the Japan Post Insurance (JPI). Regulatory valuation and solvency includes elements that allow for a long term recovery of deficits, like a sufficiency test that is only required to consider cash flows over the next 10 years. The winding up of companies allows for the amendment of existing contracts, for example, in the form of a lower guaranteed interest rate.

Table 11. Japan: Overview of Past Bankruptcy Procedures

\begin{tabular}{|c|c|c|c|c|c|c|c|}
\hline Company & $\begin{array}{l}\text { Nissan } \\
\text { Mutual }\end{array}$ & $\begin{array}{l}\text { Toho } \\
\text { Mutual }\end{array}$ & $\begin{array}{c}\text { Daihyaku } \\
\text { Mutual }\end{array}$ & Taisho & $\begin{array}{l}\text { Chiyoda } \\
\text { Mutual }\end{array}$ & Kyoei & Tokyo \\
\hline Date of bankruptcy & Apr-1997 & Jun-1999 & May-2000 & Aug-2000 & Oct-2000 & Oct-2000 & Mar-2001 \\
\hline Liquidation completion & Oct-1997 & Mar-2000 & Apr-2001 & Mar-2001 & Apr-2001 & Apr-2001 & Oct-2001 \\
\hline Negative net worth & 302.9 & 650 & 317.7 & 36.5 & 595 & 689.5 & 73.1 \\
\hline $\begin{array}{l}\text { Subordinated loans and other general } \\
\text { liabilities }\end{array}$ & Unknown & Unknown & Unknown & Unknown & All waived & All waived & All waived \\
\hline $\begin{array}{l}\text { Funds from Policyholders Protection } \\
\text { Corp. and other safety nets }\end{array}$ & 200 & 366.3 & 145 & 26.7 & - & - & - \\
\hline Reduced policy reserves (in percent) & 0 & 10 & 10 & 10 & 10 & 8 & 0 \\
\hline Goodwill & 123.2 & 240.0 & 147.0 & 7.0 & 320.0 & 364.0 & 32.5 \\
\hline $\begin{array}{l}\text { Assumed rate of return } \\
\text { prior to bankruptcy } \\
\text { after going bankruptcy (max limit) }\end{array}$ & $\begin{array}{l}\text { n.a. } \\
2.75\end{array}$ & $\begin{array}{r}4.79 \\
1.5\end{array}$ & $\begin{array}{r}4.46 \\
1\end{array}$ & $\begin{array}{r}4.05 \\
1\end{array}$ & $\begin{array}{l}3.7 \\
1.5\end{array}$ & $\begin{array}{r}4 \\
1.75\end{array}$ & $\begin{array}{l}4.2 \\
2.6\end{array}$ \\
\hline $\begin{array}{l}\text { Deduction for early termination (in } \\
\text { years) }\end{array}$ & 7.0 & 8.0 & 10.0 & 9.0 & 10.0 & 8.0 & 10.5 \\
\hline Successor or restructuring sponsor & $\begin{array}{l}\text { Aoba Life } \\
\text { Insurance } \\
\text { Co. }\end{array}$ & $\begin{array}{l}\text { GE Edison } \\
\text { Life } \\
\text { Insurance } \\
\text { Co. }\end{array}$ & $\begin{array}{l}\text { Manulife Life } \\
\text { Insurance } \\
\text { Co. }\end{array}$ & $\begin{array}{l}\text { Azami Life } \\
\text { Insurance } \\
\text { Co. }\end{array}$ & $\begin{array}{l}\text { U.S. AIG } \\
\text { Inc. }\end{array}$ & $\begin{array}{l}\text { U.S. } \\
\text { Prudential } \\
\text { Financial } \\
\text { Inc. }\end{array}$ & $\begin{array}{l}\text { Taiyo Life } \\
\text { insurance Co. } \\
\text { and Daido Life } \\
\text { Insurance Co. }\end{array}$ \\
\hline
\end{tabular}

Source: Uemura (2008).

\section{Profitability levels of the life sector have fully recovered from the $\mathbf{2 0 0 8}$ global} financial crisis and showed two years of record profits. Life insurers were affected by the 2008 crisis mainly through the depreciation of assets, but their portfolio mix, having a significant position in JGB and local equity, allowed for a fast recovery. 
Figure 2. Japan: Profit of the Life Insurance Sector, FY 2010

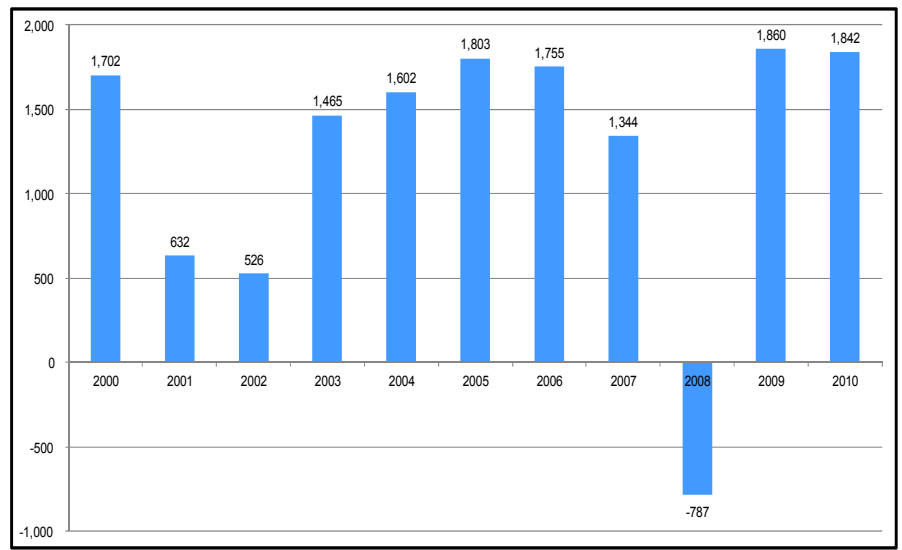

Source: Life Insurance Association of Japan.

\section{The profitability of life insurers is expected to further improve as the negative} spread is reduced. Even though the aggregate amount of premiums has not been growing, the negative spread has been reduced from an industry average of 3.3 percent in 2005, to 2.75 percent in the fiscal year ending in March 2011, and the total losses declined from $¥ 1$ trillion to $¥ 300$ billion. $^{2}$ The duration mismatch between assets and liabilities remains on average around five years. Mortality and expense gains more than offset the negative spread losses, and the sufficiency testing of the liabilities is only required to consider cash flows over the next 10 years, thus granting additional time to reduce the interest risk sensitivity.

Figure 3. Japan: Negative Spread Between Assumed Interest Rate and Investment Return
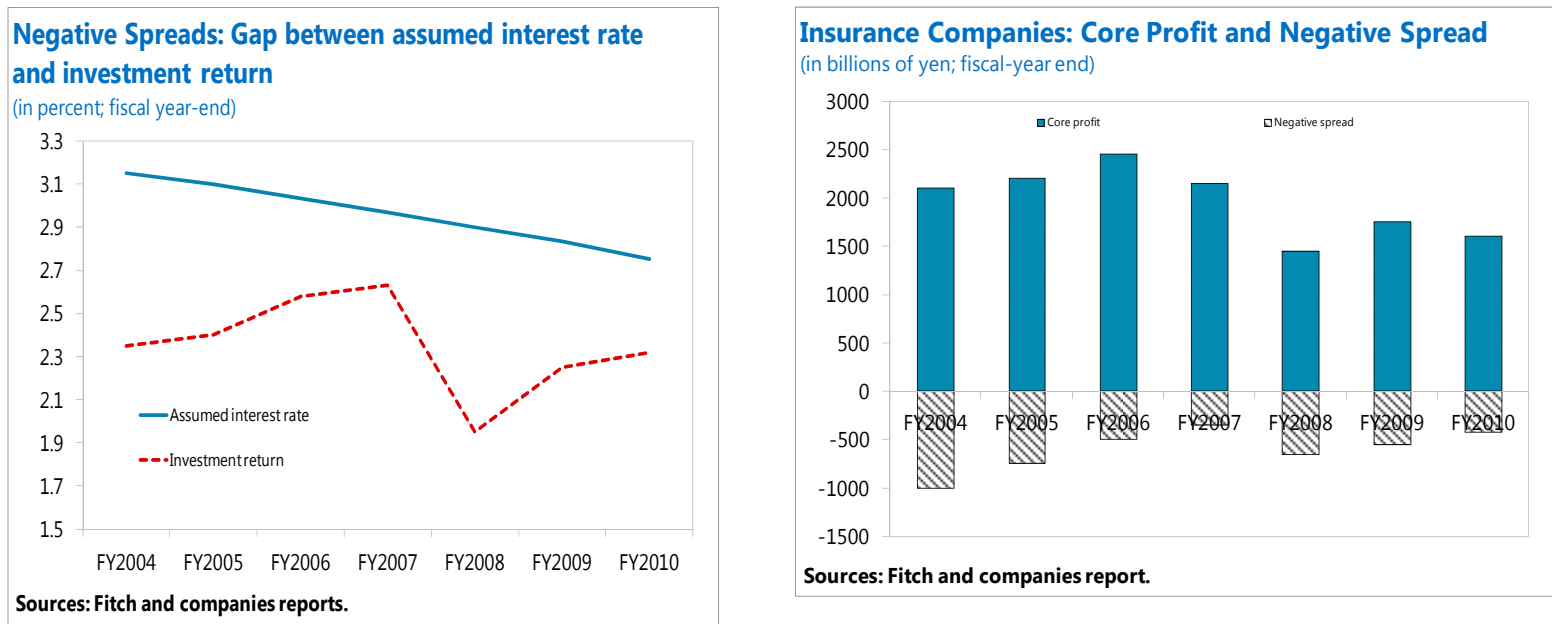

\footnotetext{
${ }^{2}$ Fitch Ratings Japan Special Report, June 2011.
} 
44. Life insurers show a strong regulatory solvency margin. Under current regulatory solvency requirements the life insurance sector is well-capitalized. With current solvency margin ratios of 500 percent or more, all insurers have sufficient capital to avoid regulatory action, which is triggered at the 200 percent level. Under the newly-established solvency requirements that take effect at the end of the current fiscal year, a reduction of 20 to 30 percent in the margin is expected, due to additional risk recognition as well as new calibration of the risk parameters. The new solvency requirements appear not to be a challenge to any of the insurers; however, economic valuation is not part of the updated requirements. The possible effects of changing to an economic valuation approach have recently been measured through a preliminary field test, but quantitative impact analysis and calibration remain to be done.

Table 12. Japan: Solvency Margins of Life Insurers

\begin{tabular}{crrrrr}
\hline Solvency Margin & \multicolumn{5}{c}{ Numbers of Insurers } \\
\cline { 2 - 6 } Levels & FY2010 & FY2009 & FY2008 & FY2007 & FY2006 \\
\hline $2000 \%$ or more & 12 & 13 & 14 & 10 & 7 \\
1500 to $1999 \%$ & 7 & 4 & 0 & 1 & 6 \\
1000 to $1499 \%$ & 18 & 18 & 7 & 18 & 18 \\
500 to $999 \%$ & 10 & 11 & 24 & 12 & 7 \\
200 to $499 \%$ & 0 & 0 & 0 & 0 & 0 \\
less than $200 \%$ & 0 & 0 & 0 & 0 & 0 \\
\hline Source: FSA. & & & & &
\end{tabular}

45. Nonlife insurers affected by the $\mathbf{2 0 0 8}$ global financial crisis are in the process of recovery. The high exposure to equities resulted in a 150 percent loss for the nonlife insurers in FY 2008. The recovery was slowed by the occurrence of the severe Great East Japan Earthquake at the end of the FY 2011, resulting in additional claims under commercial earthquake insurance in the order of $¥ 600$ billion, of which reinsurance is expected to assume $¥ 400$ billion.

\section{The expected profits for the nonlife sector during the coming years are} moderately positive. Planned increments of the motor insurance rates are expected to accelerate recovery, but exposure to global natural catastrophes has increased as the international expansion of Japanese insurers continues. With a presence in over 50 countries and the strengthening of the Japanese yen, volatility in the profits generated outside Japan remains a challenge. Competition in a stagnant local market has resulted in an increase in the combined ratio, which has exceeded 100 percent for three consecutive years, thus putting pressure on insurers to reduce expenses while maintaining service levels and complying with regulatory requirements. The recent mega mergers in the sector respond to such conditions. 
Figure 4. Japan: Profit of the Nonlife Insurance Sector, FY 2010

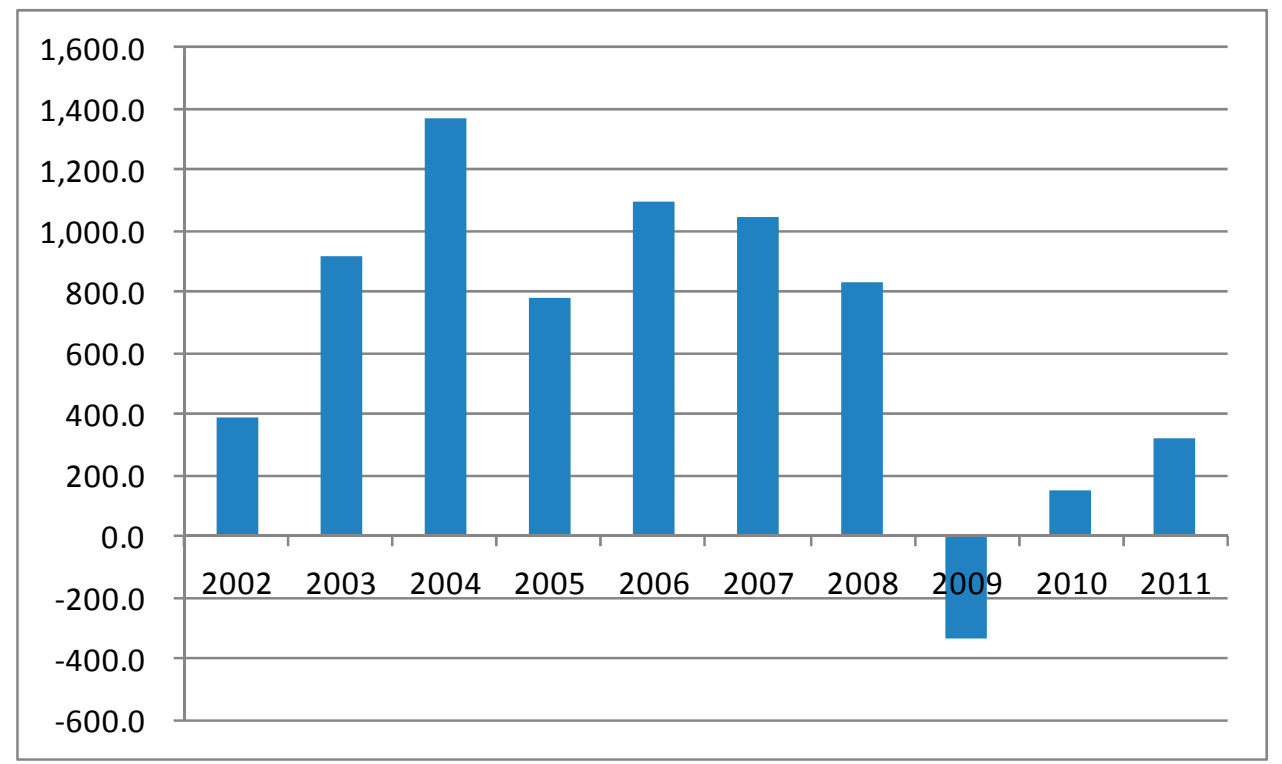

Source: General Insurance Association of Japan.

Table 13. Japan: Deterioration of Combined Ratio for Nonlife Insurance

(In percent)

\begin{tabular}{lccc}
\hline & Claim ratio & Expense ratio & Combined ratio \\
\cline { 2 - 4 } FY2001 & 59.2 & 37.0 & 96.2 \\
FY2002 & 54.7 & 34.5 & 89.1 \\
FY2003 & 55.3 & 33.2 & 88.5 \\
FY2004 & 63.6 & 32.6 & 96.2 \\
FY2005 & 60.6 & 32.1 & 92.7 \\
FY2006 & 62.0 & 32.2 & 94.3 \\
FY2007 & 62.8 & 33.2 & 96.0 \\
FY2008 & 66.6 & 35.1 & 101.7 \\
FY2009 & 68.1 & 35.0 & 103.1 \\
FY2010 & 67.5 & 34.6 & 102.1 \\
\hline S0urce: Gen
\end{tabular}

Source: General Insurance Association of Japan; data relates to member insurers 
47. The relatively large equity holdings of nonlife insurers affect their liquidity, but overall liquidity remains at a reasonable level. With a ratio of liquid assets to total liabilities of 33 percent, the liquidity level appears to be low. However, liquid assets were around twice the average of net claims paid during the last three years. The low liquidity ratio is mainly due to the long-term return-of-premium products in their portfolios. Thus, the current liquidity level should not be a financial stability concern.

Table 14. Japan: Liquidity Position of Nonlife Insurers

(In trillions of yen unless otherwise stated)

\begin{tabular}{crcr}
\hline Date & Liquid assets & Current liabilities & $\begin{array}{c}\text { Ratio (in } \\
\text { percent) }\end{array}$ \\
\hline FY2001 & 6.6 & 30.6 & 21.6 \\
FY2002 & 6.6 & 25.7 & 25.9 \\
FY2003 & 7.4 & 26.0 & 28.5 \\
FY2004 & 7.7 & 26.3 & 29.3 \\
FY2005 & 7.9 & 27.9 & 28.4 \\
FY2006 & 8.3 & 28.5 & 29.1 \\
FY2007 & 8.7 & 28.3 & 30.8 \\
FY2008 & 7.1 & 26.1 & 27.3 \\
FY2009 & 8.4 & 26.4 & 31.7 \\
FY2010 & 8.5 & 25.4 & 33.4 \\
\hline
\end{tabular}

Source: FSA

1/ Liquid assets Is the sum of cash, deposits and savings, call-loans, monetary claims bought, government bonds, and local government bonds.

48. Other financial indicators of the nonlife insurance sector suggest resilience. The ratio of net premium written to capital and surplus (the risk ratio) is 234.6 percent and capital and surplus of 10 percent of total assets are both within international norms for sound companies. The ratio of net technical provisions to the average of net claims paid during the previous three years is 493.8 percent. Foreign currency assets are less than 100 percent of capital and surplus, and the exposures are largely hedged.

\section{Nonlife insurers show a strong regulatory solvency margin, with a few}

exceptions. With 43 of the nonlife insurers having solvency margin ratios of 500 percent or more, the industry remains above the 200 percent solvency control level. In the case of nonlife insurers, the absence of economic valuation of the liabilities appears to be of less importance than for life insurers. However, the liabilities related to return-of-premium nonlife business would be affected by the adoption of such a valuation approach. Quantitative impact analysis will be necessary to evaluate such a possibility. 
Table 15. Japan: Sufficiency of the Technical Reserves of Nonlife Insurers, end-FY2011

(In trillions of yen, unless otherwise stated)

\begin{tabular}{lccc}
\hline & $\begin{array}{c}\text { Net technical } \\
\text { provisions 1/ }\end{array}$ & $\begin{array}{c}\text { Average of net } \\
\text { claims paid } \\
\text { (past 3 years) }\end{array}$ & $\begin{array}{c}\text { Ratio (in } \\
\text { percent) }\end{array}$ \\
\hline FY2001 & 25.9 & 3.9 & 658.0 \\
FY2002 & 22.8 & 3.9 & 586.0 \\
FY2003 & 22.9 & 3.9 & 587.5 \\
FY2004 & 23.0 & 4.0 & 579.0 \\
FY2005 & 23.2 & 4.2 & 556.7 \\
FY2006 & 23.4 & 4.4 & 536.7 \\
FY2007 & 23.5 & 4.4 & 534.7 \\
FY2008 & 23.1 & 4.5 & 516.7 \\
FY2009 & 22.4 & 4.5 & 500.1 \\
FY2010 & 22.0 & 4.4 & 493.8 \\
\hline
\end{tabular}

Source: FSA.

$1 /$ Net technical provisions for use of policy reserves.

Table 16. Japan: Risk Ratio Development for Nonlife Insurers

(In trillions of yen unless otherwise stated)

\begin{tabular}{lccr}
\hline & $\begin{array}{c}\text { Net Premium } \\
\text { written }\end{array}$ & $\begin{array}{c}\text { Capital and } \\
\text { surplus 1/ }\end{array}$ & $\begin{array}{r}\text { Ratio (in } \\
\text { percent) }\end{array}$ \\
\hline FY2001 & 7.7 & n.a. & n.a. \\
FY2002 & 7.4 & 3.2 & 229.0 \\
FY2003 & 7.6 & 3.2 & 235.4 \\
FY2004 & 7.4 & 3.3 & 222.5 \\
FY2005 & 7.7 & 3.4 & 225.0 \\
FY2006 & 7.8 & 3.3 & 235.5 \\
FY2007 & 7.7 & 3.4 & 228.8 \\
FY2008 & 7.4 & 3.0 & 244.3 \\
FY2009 & 7.2 & 3.2 & 225.5 \\
FY2010 & 7.1 & 3.0 & 234.6 \\
\hline F010
\end{tabular}

Source: FSA.

1/ Capital and surplus include capital, capital surplus, and earnings net of own company's shares. 
Table 17. Japan: Solvency Margins of Nonlife Insurers

\begin{tabular}{crrrrr}
\hline Solvency Margin & \multicolumn{5}{c}{ Numbers of Insurers } \\
\cline { 2 - 6 } Levels & FY2010 & FY2009 & FY2008 & FY2007 & FY2006 \\
\hline $2000 \%$ or more & 8 & 8 & 10 & 15 & 13 \\
1500 to $1999 \%$ & 4 & 8 & 3 & 3 & 3 \\
1000 to $1499 \%$ & 3 & 3 & 3 & 5 & 12 \\
500 to $999 \%$ & 28 & 26 & 25 & 24 & 14 \\
200 to 499 \% & 5 & 5 & 9 & 4 & 5 \\
less than 200 \% & 0 & 0 & 0 & 0 & 0 \\
\hline
\end{tabular}

Source: FSA.

\section{G. Summary of Observance of the Insurance Core Principles}

Table 18. Japan: Summary of Observance of the Insurance Core Principles

\begin{tabular}{|l|l|l|}
\hline $\begin{array}{c}\text { Insurance Core } \\
\text { Principle }\end{array}$ & Level & \multicolumn{1}{c|}{ Overall Comments } \\
$\begin{array}{c}\text { and } \\
\text { Responsibilities of } \\
\text { the Supervisor }\end{array}$ & O & $\begin{array}{l}\text { As a consolidated supervisor, the FSA has been able to take } \\
\text { advantage of economies of scale. However, the large part of the } \\
\text { insurance market served by cooperatives is supervised by } \\
\text { independent departments within several ministries. This could } \\
\text { potentially cause challenges of resourcing and might make it difficult } \\
\text { to achieve consistency of supervision. }\end{array}$ \\
\hline 2 - Supervisor & $\begin{array}{l}\text { While currently there are no indications of political interference in the } \\
\text { supervision of insurers, the legal framework governing the FSA } \\
\text { contains elements that could undermine the independence and } \\
\text { capacity of the supervisor. For example, the budget must be } \\
\text { approved by appointed and elected government officials, which } \\
\text { leaves it exposed to cutbacks for financial or political reasons. } \\
\text { The FSA has been strengthening its insurance regulatory framework } \\
\text { and is improving the tools used for supervisory assessment. } \\
\text { Industry participants appreciate the proactive manner in which the } \\
\text { FSA consults on regulatory and supervisory changes. The FSA } \\
\text { expects industry participants to act in accordance with the guidance } \\
\text { provided by both the Supervisory Guideline and the Inspection } \\
\text { Manuals. However, the manner which the expectations are } \\
\text { expressed could affect both their enforceability and their } \\
\text { transparency. } \\
\text { It is important that the public have ready access to financial and } \\
\text { statistical information about insurers and intermediaries. Japanese } \\
\text { industry associations publish industry-wide information and } \\
\text { information about individual insurers and insurance groups is } \\
\text { available on their respective websites. However, it would be better } \\
\text { for the public to be able to obtain both industry-wide and entity- } \\
\text { specific information from a single, reliable, and consistent source of } \\
\text { information. This would not only facilitate the ability of others to } \\
\text { perform analyses and contribute to market discipline. } \\
\text { Many supervisors make use of outside experts to improve their }\end{array}$ \\
\hline
\end{tabular}




\begin{tabular}{|c|c|c|}
\hline & & $\begin{array}{l}\text { effectiveness, for example, by contracting with persons having } \\
\text { specialized expertise in an emerging area of industry activity. }\end{array}$ \\
\hline $\begin{array}{l}3 \text { - Information } \\
\text { Exchange and } \\
\text { Confidentiality } \\
\text { Requirements }\end{array}$ & $\mathrm{O}$ & $\begin{array}{l}\text { The positive response to specific requests from foreign supervisors } \\
\text { could be enhanced by a more proactive exchange of information } \\
\text { with all relevant supervisors. } \\
\text { The exchange of information with a foreign supervisor could be } \\
\text { delayed if the FSA has not previously checked the confidentiality } \\
\text { regime of the foreign jurisdiction. }\end{array}$ \\
\hline 4 - Licensing & $\mathrm{O}$ & $\begin{array}{l}\text { Although it is clear that an insurer is licensed for either life insurance } \\
\text { or nonlife insurance, the specific classes of insurance that the FSA } \\
\text { has approved the insurer to underwrite are not publicly disclosed. } \\
\text { Such information can be useful to consumers and intermediaries. }\end{array}$ \\
\hline $\begin{array}{c}5 \text { - Suitability of } \\
\text { Persons }\end{array}$ & LO & $\begin{array}{l}\text { Suitability requirements should formally apply to all persons who } \\
\text { hold have key roles in the governance and operation of an insurer. } \\
\text { This reinforces the need for insurers to select suitable persons for } \\
\text { such roles. It also strengthens the supervisor's ability to take } \\
\text { corrective action. Currently, there are some gaps in the scope of } \\
\text { suitability requirements. } \\
\text { In some jurisdictions, legislation permanently prohibits persons who } \\
\text { have been convicted of financial crimes from holding key roles in the } \\
\text { governance and operation of an insurer. This strengthens the ability } \\
\text { of the supervisor to declare such persons to be unfit. }\end{array}$ \\
\hline $\begin{array}{l}6 \text { - Changes in Control } \\
\text { and Portfolio } \\
\text { Transfers }\end{array}$ & $\mathrm{O}$ & $\begin{array}{l}\text { The experience gained through the significant number of portfolio } \\
\text { transfers in the late } 1990 \text { s and early } 2000 \text { s has been reflected both } \\
\text { in the legal framework and in practice. }\end{array}$ \\
\hline $\begin{array}{l}7 \text { - Corporate } \\
\text { Governance }\end{array}$ & LO & $\begin{array}{l}\text { Corporate governance in Japan has improved, but independence } \\
\text { remains weak. While a few insurers have a board structure with a } \\
\text { clear segregation between board members and senior management } \\
\text { in place, the majority of the insurers and insurance holding } \\
\text { companies maintain the traditional structure of a board largely } \\
\text { comprised of senior management overseen by an audit board. } \\
\text { However, the board of corporate auditors has limited powers; for } \\
\text { example, it cannot dismiss directors or call for a shareholders } \\
\text { meeting, which could compromise the timeliness and effectiveness } \\
\text { of its interventions. Its work is largely performed by full-time } \\
\text { members who were previously part of management, and fit and } \\
\text { proper requirements under the IBA do not apply to corporate } \\
\text { auditors and apply only to a limited extent to part-time directors. } \\
\text { Also, many insurers-even those with a monitoring board } \\
\text { structure-have few outside directors on their boards. As well as } \\
\text { improving oversight, a larger proportion of outside directors could be } \\
\text { useful in providing management with additional, independent views } \\
\text { on business matters. Furthermore, the definition of "outside" is less } \\
\text { restrictive than it might be; for example, it does not exclude the } \\
\text { spouse of a senior executive. }\end{array}$ \\
\hline
\end{tabular}




\begin{tabular}{|c|c|c|}
\hline $\begin{array}{l}8 \text { - Risk Management } \\
\text { and Internal } \\
\text { Controls }\end{array}$ & $\mathrm{O}$ & $\begin{array}{l}\text { In recent years, the FSA has more strongly emphasized the } \\
\text { importance of risk management and internal controls, and some } \\
\text { insurers have sophisticated systems in place. } \\
\text { Listed companies are required to provide additional assurance on } \\
\text { the adequacy of their internal controls, under "J-SOX." }\end{array}$ \\
\hline $\begin{array}{c}9 \text { - Supervisory } \\
\text { Review and } \\
\text { Reporting }\end{array}$ & LO & $\begin{array}{l}\text { The FSA has been improving the tools used for supervisory } \\
\text { assessment. As mentioned under ICP 2, the FSA should build on } \\
\text { this by completing the development of a methodology for risk-rating } \\
\text { insurers and adopting a structured system for the internal review of } \\
\text { risk assessments. } \\
\text { Legislation does not require foreign branches to have the financial } \\
\text { information that they submit audited. The FSA has made this a } \\
\text { condition of licensing, and individually informs applicants for foreign } \\
\text { branch licenses of the requirement. However, this requirement } \\
\text { should be both strong and transparent. } \\
\text { The external auditors of an insurer can be a valuable source of } \\
\text { information for supervisors. In some jurisdictions, the legal } \\
\text { framework includes provisions that enable supervisors to place } \\
\text { greater reliance on the work of external auditors. They include giving } \\
\text { external auditors the right to provide information to the supervisor } \\
\text { without being subject to lawsuit for breaching confidentiality, } \\
\text { requiring external auditors to report to the supervisor significant } \\
\text { adverse information that has come to their attention in the course of } \\
\text { an audit, enabling the supervisor to review the working papers of the } \\
\text { external auditors, and empowering the supervisor to require the } \\
\text { external auditor to increase the scope of their audit or to perform a } \\
\text { special audit at the expense of the company. } \\
\text { The FSA's inspections of insurers appear to be comprehensive and } \\
\text { industry representatives have indicated that the findings have been } \\
\text { useful to them in improving their operations. However, the time } \\
\text { between inspections is longer than it should be. }\end{array}$ \\
\hline $\begin{array}{l}10 \text { - Preventive and } \\
\text { Corrective } \\
\text { Measures }\end{array}$ & LO & $\begin{array}{l}\text { The FSA requires insurers to take steps to deal with identified } \\
\text { weaknesses, but its intervention efforts could be enhanced. The } \\
\text { adoption of a risk-rating system (see ICP 2) and the revision of } \\
\text { solvency margin control levels (see ICP 17) would support the FSA's } \\
\text { ability to take early preventive and corrective measures. } \\
\text { The FSA prefers to deal with minor regulatory violations through } \\
\text { dialogue and moral suasion, which it has found effective in securing } \\
\text { corrective actions. Minor sanctions are not being applied. At the } \\
\text { same time, the formal supervisory administrative action threshold } \\
\text { appears to be high, based on the limited number of such actions } \\
\text { taken in the last } 10 \text { years. }\end{array}$ \\
\hline
\end{tabular}




\begin{tabular}{|c|c|c|}
\hline 11 -Enforcement & $\mathrm{O}$ & $\begin{array}{l}\text { In many jurisdictions, the supervisory authority has the power to } \\
\text { impose monetary penalties through administrative means for clearly- } \\
\text { defined and less significant breaches of legislation, such as the late } \\
\text { or erroneous submission of required information. This power } \\
\text { supplements its ability to seek court action to deal with major } \\
\text { breaches. }\end{array}$ \\
\hline $\begin{array}{l}12 \text {-Winding-up and Exit } \\
\text { from the Market }\end{array}$ & $\mathrm{O}$ & $\begin{array}{l}\text { The possibility of amending insurance contract conditions where it is } \\
\text { highly probable that the continuation of an insurer's business will be } \\
\text { difficult is a useful tool in dealing with a failed insurer. Such } \\
\text { amendments are subject to various conditions, which are designed } \\
\text { to protect consumers. }\end{array}$ \\
\hline $\begin{array}{l}13 \text { - Reinsurance and } \\
\text { Other Forms of Risk } \\
\text { Transfer }\end{array}$ & LO & $\begin{array}{l}\text { Japan's exposure to natural catastrophes makes strong reinsurance } \\
\text { coverage essential to the Japanese insurance market and overall } \\
\text { economy. The FSA reviews the reinsurance strategies and programs } \\
\text { of insurers, but the regulation and supervision of reinsurance could } \\
\text { be strengthened. }\end{array}$ \\
\hline 14 -Valuation & $\mathrm{PO}$ & $\begin{array}{l}\text { Solvency assessment should be based on a transparent economic } \\
\text { valuation of assets and liabilities, which takes into account future } \\
\text { cash flows over the full time horizon. The current methods of valuing } \\
\text { insurance liabilities do not meet these criteria (standards } 14.8 \text { and } \\
\text { 14.9), which creates the risk that liabilities are not being fully } \\
\text { recognized. The combination of basic amortized-cost valuations } \\
\text { using conservative assumptions, additional provisions based on the } \\
\text { testing of cash flows, and supplemental reserves is difficult to } \\
\text { understand. Although future cash flows over the full time horizon are } \\
\text { taken into account in the initial valuation of liabilities, this is not } \\
\text { necessarily the case in the subsequent testing of their sufficiency, for } \\
\text { which only cash flows during the next } 10 \text { years are required to be } \\
\text { considered. The approach to cash flow testing in respect of the } \\
\text { negative spread, as well as the absence of an explicit valuation of } \\
\text { some options and guarantees, create the possibility that liabilities } \\
\text { might be understated. } \\
\text { The FSA is currently considering the possibility of moving to a } \\
\text { valuation approach that is more closely related to economic value. In } \\
\text { addition, the FSA is considering that costs regarding options and } \\
\text { guarantees will be taken into account when insurance liabilities are } \\
\text { calculated. }\end{array}$ \\
\hline 15 -Investment & $\mathrm{O}$ & $\begin{array}{l}\text { The FSA is considering changes to the investment regulations to } \\
\text { give insurers more flexibility in their investment strategies. For } \\
\text { example, such changes might include eliminating the quantitative } \\
\text { limit on equity investments, which is increasingly affecting some } \\
\text { nonlife insurers as their long-term, premium-refund business } \\
\text { declines. At the same time, some insurers are actively reducing their } \\
\text { exposure to equities in order to reduce market risk and improve } \\
\text { returns (in the case of equities purchased as a way to attract } \\
\text { insurance business from the issuers). } \\
\text { Some jurisdictions supplement quantitative investment limitations } \\
\text { with an overriding requirement that insurers invest in the manner of a } \\
\text { prudent person. Such a requirement can be particularly useful-both }\end{array}$ \\
\hline
\end{tabular}




\begin{tabular}{|c|c|c|}
\hline & & $\begin{array}{l}\text { in reinforcing the need for good behavior and empowering } \\
\text { supervisory intervention-if quantitative investment limitations are } \\
\text { being relaxed. }\end{array}$ \\
\hline $\begin{array}{l}16 \text {-Enterprise Risk } \\
\text { Management for } \\
\text { Solvency Purposes }\end{array}$ & LO & $\begin{array}{l}\text { Enterprise risk management is an evolving field, both in Japan and } \\
\text { internationally. Some Japanese insurers have sophisticated } \\
\text { enterprise risk management systems, while others are at earlier } \\
\text { stages of development. } \\
\text { The Supervisory Guideline was revised to deal more extensively with } \\
\text { risk management in response to the global financial crisis, while the } \\
\text { Inspection Manual was updated in } 2011 \text { to include a section explicitly } \\
\text { on this topic. Through interviews, the FSA has done a thematic } \\
\text { review of the enterprise risk management processes of selected } \\
\text { insurers. }\end{array}$ \\
\hline 17 -Capital Adequacy & LO & $\begin{array}{l}\text { It is important that solvency requirements be sufficiently strong, while } \\
\text { not being onerous. There are various steps that can be taken to } \\
\text { achieve this balance, such as requiring insurers to model risks } \\
\text { internally and reviewing the results, and comparing the requirements } \\
\text { with those of other jurisdictions with similarly sophisticated insurance } \\
\text { markets. For the most recent revisions, the risk parameters were } \\
\text { calculated by the FSA, based on historical experience. } \\
\text { It has been at least } 10 \text { years since any insurer has fallen below the } \\
200 \text { percent solvency control level-including an insurer that failed. } \\
\text { Even with the recent strengthening of the risk weights, most insurers } \\
\text { are likely to remain well above the control levels. In order to serve as } \\
\text { an effective supervisory tool, the highest solvency control level } \\
\text { should be closer to the level of that insurers typically maintain in } \\
\text { order to be considered strong internally and by market participants. } \\
\text { The FSA does not impose variations to the solvency margin } \\
\text { requirements on individual insurers. The supervisors in some } \\
\text { jurisdictions do so, for example, to take account of risk } \\
\text { characteristics of an insurer that is not fully captured by the } \\
\text { standardized formulas. } \\
\text { Very few insurers are using internal models for solvency margin } \\
\text { calculations. However, the requests to do so are likely to increase in } \\
\text { the future, as insurers build their enterprise risk management } \\
\text { capabilities and gain comfort in using the related models. }\end{array}$ \\
\hline 18 -Intermediaries & LO & $\begin{array}{l}\text { Onsite inspection is an important tool in the supervision of both } \\
\text { insurers and insurance intermediaries. }\end{array}$ \\
\hline 19 -Conduct of Business & $\mathrm{O}$ & $\begin{array}{l}\text { Some supervisors have created units responsible for taking the lead } \\
\text { on customer protection, which helps to ensure that such issues are } \\
\text { identified in a timely manner and dealt with appropriately. }\end{array}$ \\
\hline 20 -Public Disclosure & LO & $\begin{array}{l}\text { Currently, few insurers are using internal models to calculate the } \\
\text { solvency requirements for catastrophe risks. However, those that do } \\
\text { so are not required to disclose information about such models. } \\
\text { Insurers disclose a significant amount of information, some of which } \\
\text { goes beyond the legally-required disclosures. However, there are } \\
\text { some areas that should be strengthened. }\end{array}$ \\
\hline
\end{tabular}




\begin{tabular}{|c|c|c|}
\hline & & $\begin{array}{l}\text { Insurers disclose their exposures to reinsurers by ratings category. } \\
\text { This is useful information, but it does not enable users to assess the } \\
\text { possible effects of reinsurance concentrations. }\end{array}$ \\
\hline $\begin{array}{l}21 \text { - Countering Fraud in } \\
\text { Insurance }\end{array}$ & $\mathrm{O}$ & $\begin{array}{l}\text { Fraud in insurance has not been a significant problem in Japan. } \\
\text { Relatively few cases of fraud have been reported, but there are no } \\
\text { statistics on the extent of fraud or its cost to insurers-and ultimately, } \\
\text { to consumers. This situation might change, for example, as insurers } \\
\text { develop new products that provide different types of living benefits } \\
\text { than traditional products. In some jurisdictions, insurers cooperate in } \\
\text { a formal manner to share information that supports the detection of } \\
\text { fraud. }\end{array}$ \\
\hline $\begin{array}{l}22 \text {-Anti-Money } \\
\text { Laundering and } \\
\text { Combating the } \\
\text { Financing of } \\
\text { Terrorism }\end{array}$ & $\mathrm{O}$ & $\begin{array}{l}\text { The AML/CFT efforts of insurers and intermediaries should be } \\
\text { inspected regularly. }\end{array}$ \\
\hline $\begin{array}{l}23 \text { - Group-wide } \\
\text { Supervision }\end{array}$ & $\mathrm{O}$ & $\begin{array}{l}\text { Group-wide solvency requirements have been adopted, which } \\
\text { insurance holding companies must meet by March } 2012 \text { (the end of } \\
\text { the fiscal year). }\end{array}$ \\
\hline $\begin{array}{l}24 \text { - Macroprudential } \\
\text { Surveillance and } \\
\text { Insurance } \\
\text { Supervision }\end{array}$ & PO & $\begin{array}{l}\text { The IAIS and other international organizations are currently } \\
\text { considering how to define and deal with global systemically- } \\
\text { important financial institutions. Such considerations are quite } \\
\text { relevant to Japan, in light of the size and concentration of its } \\
\text { insurance sector. }\end{array}$ \\
\hline $\begin{array}{l}25 \text { - Supervisory } \\
\text { Cooperation and } \\
\text { Coordination }\end{array}$ & LO & $\begin{array}{l}\text { The FSA serves as the group-wide supervisor of Japanese } \\
\text { insurance groups, but in some cases does not regularly } \\
\text { communicate with foreign host supervisors. }\end{array}$ \\
\hline $\begin{array}{l}26 \text { - Cross-border } \\
\text { Cooperation and } \\
\text { Coordination on } \\
\text { Crisis Management }\end{array}$ & PO & $\begin{array}{l}\text { Cross-border cooperation and coordination specifically related to } \\
\text { crisis management of Japanese insurers is in its initial stages. }\end{array}$ \\
\hline
\end{tabular}




\section{H. Recommendations and the Authorities' Responses}

\section{Recommendations to improve observance of ICPs}

\section{Table 19. Japan: Recommendations to Improve Observance of ICPs}

\begin{tabular}{|c|c|}
\hline Insurance Core Principle & Recommendations \\
\hline $\begin{array}{l}1 \text { - Objectives, Powers and } \\
\text { Responsibilities of the Supervisor }\end{array}$ & $\begin{array}{l}\text { To help ensure that the objectives of insurance supervision } \\
\text { are pursued in a consistent manner with respect to all parts of } \\
\text { the Japanese insurance sector, the FSA and the responsible } \\
\text { ministries should consider establishing a process that would } \\
\text { facilitate the regular exchange of views on the objectives of } \\
\text { insurance supervision and the manner in which those } \\
\text { objectives might be achieved. Alternatively, the government } \\
\text { might consider centralizing insurance supervision with the } \\
\text { FSA. }\end{array}$ \\
\hline 2 - Supervisor & $\begin{array}{l}\text { Consideration should be given to having the FSA financed in a } \\
\text { manner that does not involve negotiation of its budget, such } \\
\text { as by legally-enforceable levies on the industry, which could } \\
\text { be useful in strengthening both its independence and its } \\
\text { resources. } \\
\text { The FSA should complete the development of a methodology } \\
\text { for risk-rating insurers, adopting a structured system for the } \\
\text { internal review of risk assessments, and further increasing the } \\
\text { level of resources to enable inspections to be performed more } \\
\text { frequently-particularly for the largest insurers. } \\
\text { The FSA should consider making some expectations into } \\
\text { requirements within the IBA or secondary legislation and } \\
\text { communicate important expectations through the Supervisory } \\
\text { Guideline rather than the Inspection Manuals. } \\
\text { The FSA should make information about the industry, } \\
\text { individual insurers, insurance groups, and intermediaries } \\
\text { available on its website. } \\
\text { The FSA should consider the possibility of using outside } \\
\text { experts to supplement its staff resources. }\end{array}$ \\
\hline $\begin{array}{l}3 \text { - Information Exchange and } \\
\text { Confidentiality Requirements }\end{array}$ & $\begin{array}{l}\text { The FSA should consider expanding its distribution list of } \\
\text { relevant supervisors that might be interested in various types } \\
\text { of information. } \\
\text { To minimize the risk of delays and facilitate proactive, two-way } \\
\text { exchanges of information, the FSA should check the } \\
\text { confidentiality regimes of all relevant home and host } \\
\text { jurisdictions before a specific need arises. }\end{array}$ \\
\hline 4 - Licensing & $\begin{array}{l}\text { The FSA should consider publishing information regarding the } \\
\text { classes of insurance each insurer has been approved to } \\
\text { underwrite. } \\
\text { As commented under ICP 9, the legislation should be } \\
\text { amended to require foreign branches to submit audited } \\
\text { financial information, so that this requirement will be both } \\
\text { strengthened and published. }\end{array}$ \\
\hline
\end{tabular}




\begin{tabular}{|c|c|}
\hline 5 - Suitability of Persons & $\begin{array}{l}\text { The legislation should be revised to extend the application of } \\
\text { suitability requirements to part-time directors, corporate } \\
\text { auditors, and all executive officers. } \\
\text { The FSA should consider seeking an amendment to } \\
\text { legislation to strengthen its ability to disqualify persons who } \\
\text { have been convicted of financial crimes from holding key roles } \\
\text { in the governance and operation of an insurer. }\end{array}$ \\
\hline $\begin{array}{l}6 \text { - Changes in Control and Portfolio } \\
\text { Transfers }\end{array}$ & None. \\
\hline 7 - Corporate Governance & $\begin{array}{l}\text { The corporate governance and suitability requirements should } \\
\text { be revised to strengthen independent oversight, which will } \\
\text { reinforce the supervisory efforts of the FSA. } \\
\text { As indicated under ICP 2, the FSA should consider making } \\
\text { some of its expectations regarding corporate governance into } \\
\text { legally-binding requirements under the IBA or secondary } \\
\text { legislation. }\end{array}$ \\
\hline $\begin{array}{l}8 \text { - Risk Management and Internal } \\
\text { Controls }\end{array}$ & $\begin{array}{l}\text { The FSA should consider whether all insurers should be } \\
\text { subject to the internal control requirements currently } \\
\text { applicable to listed companies. }\end{array}$ \\
\hline 9 - Supervisory Review and Reporting & $\begin{array}{l}\text { The FSA should complete the development of a methodology } \\
\text { for risk-rating insurers and adopt a structured system for the } \\
\text { internal review of risk assessments. } \\
\text { The legislation should be amended to require foreign } \\
\text { branches to submit audited financial information. } \\
\text { The arrangements for communication with the external } \\
\text { auditors should be enhanced, for example, by meeting } \\
\text { regularly with the external auditors and revising the legal } \\
\text { framework to include measures that would enable the FSA to } \\
\text { place greater reliance on their work. } \\
\text { The FSA should increase the frequency of its inspections. For } \\
\text { example, it might inspect all large insurers at least once every } \\
\text { two years, high-risk insurers at least annually, and other } \\
\text { insurers at least once every three years. }\end{array}$ \\
\hline 10 -Preventive and Corrective Measures & $\begin{array}{l}\text { The FSA should make greater use of the tools available to it, } \\
\text { such as the power to impose fines on insurers and } \\
\text { intermediaries, to develop a more progressive approach to } \\
\text { enforcement. }\end{array}$ \\
\hline 11 -Enforcement & $\begin{array}{l}\text { The FSA might consider the applicability of administrative } \\
\text { monetary penalties in Japan and, if appropriate, the legislation } \\
\text { should be revised accordingly. }\end{array}$ \\
\hline 12 -Winding-up and Exit from the Market & $\begin{array}{l}\text { The FSA should consider seeking an amendment to the IBA to } \\
\text { further protect the rights and entitlements of nonlife insurance } \\
\text { policyholders, by extending to them the same preference on } \\
\text { winding-up currently provided to life insurance policyholders. }\end{array}$ \\
\hline $\begin{array}{l}13 \text { - Reinsurance and Other Forms of Risk } \\
\text { Transfer }\end{array}$ & $\begin{array}{l}\text { The FSA should consider measures such as stronger } \\
\text { documentation requirements (including the prohibition of side } \\
\text { letters) and a more formal assessment of the manner in which } \\
\text { foreign reinsurers are supervised. }\end{array}$ \\
\hline
\end{tabular}




\begin{tabular}{|c|c|}
\hline & $\begin{array}{l}\text { The exclusion of the cooperatives' insurance programs from } \\
\text { the national earthquake pool might be reconsidered, as it } \\
\text { could affect the solvency of those cooperatives in case of a } \\
\text { major event or the failure of reinsurers. }\end{array}$ \\
\hline 14 -Valuation & $\begin{array}{l}\text { The FSA should revise its valuation approach to take fuller } \\
\text { account of emerging experience and anticipated future } \\
\text { experience. }\end{array}$ \\
\hline 15 - Investment & $\begin{array}{l}\text { The FSA might consider whether the inclusion of a prudent } \\
\text { person requirement in the IBA would be useful in Japan. }\end{array}$ \\
\hline $\begin{array}{l}16 \text {-Enterprise Risk Management for } \\
\text { Solvency Purposes }\end{array}$ & $\begin{array}{l}\text { The FSA should enhance its guidance on enterprise risk } \\
\text { management to indicate that insurers should explicitly } \\
\text { describe the relationship between their risk tolerance limits, } \\
\text { regulatory capital requirements, economic capital, and the } \\
\text { processes and methods for monitoring risk. It should also } \\
\text { provide more explicit guidance regarding the performance of } \\
\text { own risk and solvency assessment. The FSA should } \\
\text { encourage insurers to include the target asset mix as part of } \\
\text { their investment policies. It should also consider incorporating } \\
\text { basic requirements to perform enterprise risk management in } \\
\text { the legislation, and communicate more specific expectations } \\
\text { through the Supervisory Guideline. } \\
\text { The FSA should actively supervise the efforts of insurers in } \\
\text { this area, to help ensure that their capabilities are evolving at } \\
\text { an appropriate pace. }\end{array}$ \\
\hline 17 -Capital Adequacy & $\begin{array}{l}\text { The required solvency margin should include risk margins for } \\
\text { any mismatching of assets and liabilities, not just a risk margin } \\
\text { for interest-rate risk. The required solvency margin should also } \\
\text { be enhanced to consider the ratings of reinsurers in the risk } \\
\text { weights applied to reinsurance credit exposures. } \\
\text { In the future, the FSA should consider enhancing the process } \\
\text { of revising solvency requirements by asking insurers to model } \\
\text { risk scenarios and making detailed comparisons to the } \\
\text { solvency regimes of other jurisdictions. } \\
\text { The FSA should consider increasing the solvency control } \\
\text { levels. } \\
\text { The FSA should consider imposing variations to the solvency } \\
\text { margin requirements in cases where the risk characteristics of } \\
\text { individual insurers are not fully captured by the standardized } \\
\text { formulas. } \\
\text { The FSA should update its model approval standards to } \\
\text { conform to current best practices. }\end{array}$ \\
\hline 18 -Intermediaries & $\begin{array}{l}\text { The FSA should perform periodic onsite inspections of } \\
\text { brokers, even though they account for a small share of the } \\
\text { market in Japan. } \\
\text { Consideration should also be given to making it a legal } \\
\text { requirement that all insurance intermediaries pass } \\
\text { examinations as a condition of registration. }\end{array}$ \\
\hline 19 -Conduct of Business & The FSA might consider creating a customer protection unit. \\
\hline
\end{tabular}




\begin{tabular}{|c|c|}
\hline 20 -Public Disclosure & $\begin{array}{l}\text { The disclosure requirements should be revised to require the } \\
\text { public disclosure of information about the internal models used } \\
\text { to calculate the solvency requirements for catastrophe risks. } \\
\text { The FSA should enhance the requirements to include the } \\
\text { disclosure of information such as: } \\
\text { - The level of sensitivity of investment values to market } \\
\text { variables; } \\
\text { - The methodology used and the key assumptions } \\
\text { employed in measuring assets and liabilities for ALM } \\
\text { purposes; } \\
\text { - A quantitative analysis of sources of earnings; } \\
\text { - Quantitative information about material risk } \\
\text { exposures, including concentrations; and } \\
\text { - The nature of stress testing being performed. } \\
\text { The FSA should consider requiring the disclosure of } \\
\text { reinsurance premium concentration ratios. }\end{array}$ \\
\hline 21 -Countering Fraud in Insurance & $\begin{array}{l}\text { The FSA should encourage the industry associations to } \\
\text { maintain industry-wide data bases to help detect fraud. }\end{array}$ \\
\hline $\begin{array}{l}22 \text {-Anti-Money Laundering and } \\
\text { Combating the Financing of Terrorism }\end{array}$ & $\begin{array}{l}\text { The FSA should reinforce its supervision of AML/CFT through } \\
\text { more frequent onsite inspections of insurers and } \\
\text { intermediaries (see ICPs } 9 \text { and 18). }\end{array}$ \\
\hline 23 -Group-wide Supervision & None. \\
\hline $\begin{array}{l}24 \text { - Macroprudential Surveillance and } \\
\text { Insurance Supervision }\end{array}$ & $\begin{array}{l}\text { The FSA should not only remain actively engaged in the } \\
\text { international discussions, but also deal with the issue of } \\
\text { systemically-important insurers for its own market. } \\
\text { Some steps should be taken to enhance the macroprudential } \\
\text { value of the information currently being prepared by the FSA. } \\
\text { The FSA should develop a comprehensive process for } \\
\text { bringing together the various pieces of information, identifying } \\
\text { issues of possible macroprudential importance to the } \\
\text { insurance sector (and the financial sector more broadly), } \\
\text { formulating adverse scenarios for further consideration, and } \\
\text { communicating the results of this analysis internally and with } \\
\text { other Japanese supervisory authorities. The effects of the } \\
\text { adverse scenarios should be assessed quantitatively, through } \\
\text { either top-down stress testing by the FSA or bottom-up stress } \\
\text { testing of prescribed scenarios by the insurers. } \\
\text { The FSA should also contribute to the ability of others to } \\
\text { analyze the industry by making market data publicly available. }\end{array}$ \\
\hline $\begin{array}{l}25 \text { - Supervisory Cooperation and } \\
\text { Coordination }\end{array}$ & $\begin{array}{l}\text { The FSA should establish supervisory colleges for Japanese } \\
\text { insurers with material foreign operations, supported by } \\
\text { adequate staff and financial resources, and use the colleges } \\
\text { to enhance cooperation and coordination. }\end{array}$ \\
\hline
\end{tabular}


26 - Cross-border Cooperation and Coordination on Crisis Management
The FSA should develop comprehensive plans for dealing with insurers in crisis and ensure that it has the tools needed to carry out such plans. It should ensure that the plans are internationally-coordinated by working with foreign supervisors, for example, through supervisory colleges.

Insurers should be required to prepare contingency plans, which should include specific procedures for use in a goneconcern situation.

Authorities' response to the assessment

50. The Japanese authorities welcome the opportunity to be assessed as the first jurisdiction under the newly revised version of the Insurance Core Principles (ICPs), which was published in October 2011. The authorities also wish to express their sincere appreciation to the IMF and its experienced assessors for the dedication, time and resources committed to this assessment. It provided the authorities with the opportunity to comprehensively review their regulatory and supervisory framework through their selfassessments and dialogue with the IMF.

51. The authorities also welcome the overall assessment by the IMF that they have achieved a high level of compliance with the ICPs. The recommendations made by the IMF are generally well received. While some initiatives towards reform are already taken since the time of the assessment, the authorities will thoroughly take into account these recommendations in the course of their continuous efforts to strengthen their capacities for better regulation and supervision.

52. However, it should also be noted that there were some differences of views between the IMF and the authorities in interpreting the 2011 version of the ICPs. For example, ICP 14 contains a passage based on a compromise among the IAIS members in the form of employing a broader interpretation of "economic valuation" while the relevant accounting standards are still very much being developed by accounting standard-setters, particularly IFRS 4.

53. More broadly, full and immediate compliance with newly developed standards is a major challenge for all. One example is ICP 24; it requires a macroprudential surveillance framework in the insurance sector, which is still being designed and developed in most jurisdictions, and it will take some time for the best practices in this area to be established.

\section{The authorities aim to pursue their approach of "better regulation" through} creating incentives for enhancing effective management on the part of insurers, while the IMF appears to place more emphasis on a rules-based approach, combined with the imposition of strict penalties including fines when the rules are breached. The authorities believe that encouraging insurers to enhance the effectiveness of their management through close monitoring by and communication with the authorities is a key element of effective 
regulation and supervision. The authorities also believe that proper regulation and appropriate supervision should incentivize insurers to identify the issues themselves and take corrective measures on their own, and fines and other penalties should play only a complementary role. The authorities would maintain that such an approach improves the quality of the insurance sector more effectively, and should be an integral part of the "better regulation" they aim to pursue.

\section{Detailed ASSESSMent}

The assessment methodology established by the IAIS is attached in the Appendix, which contains an excerpt from "Insurance Core Principles, Standards, Guidance and Assessment Methodology" (IAIS, October 1, 2011).

\section{Table 20. Japan: Detailed Assessment of Observance of the Insurance Core Principles}

\begin{tabular}{|c|c|}
\hline ICP 1 & $\begin{array}{l}\text { Objectives, Powers and Responsibilities of the Supervisor } \\
\text { The authority (or authorities) responsible for insurance supervision and the objectives } \\
\text { of insurance supervision are clearly defined. }\end{array}$ \\
\hline Description & $\begin{array}{l}\text { The Law on the Establishment of the Financial Services Agency (LEFSA) defines the } \\
\text { Financial Services Agency (FSA) as the authority generally responsible for supervision } \\
\text { of the insurance business. } \\
\text { The Insurance Business Act (IBA), the primary legislation through which the insurance } \\
\text { business is regulated, identifies some insurance activities as being outside its scope } \\
\text { and therefore not supervised by the FSA. They include captives and business } \\
\text { transacted by labor unions with their members, neither of which is subject to } \\
\text { supervision. They also include insurance activities that are subject to other Acts; the } \\
\text { insurance activities of cooperatives are subject to other Acts and are supervised by the } \\
\text { government ministries responsible for the relevant sectors. For example, the insurance } \\
\text { activities of agricultural cooperatives are regulated by the Agricultural Cooperatives Act } \\
\text { and supervised by the Ministry of Agriculture, Forestry, and Fisheries. The legislation } \\
\text { related to the insurance activities of cooperatives is similar to the IBA and the various } \\
\text { ministries communicate with the FSA on policy matters. However, this assessment } \\
\text { focuses on the insurance activities that are regulated by the IBA and supervised by the } \\
\text { FSA. } \\
\text { The LEFSA defines objectives for the FSA, which include ensuring the stability of the } \\
\text { financial system in Japan, protecting depositors, insurance policyholders and securities } \\
\text { investors, and ensuring smooth finance functions. The IBA states its purpose as being } \\
\text { to protect policyholders by ensuring sound and appropriate management of persons } \\
\text { carrying on insurance business and fairness of insurance solicitation, and thereby to } \\
\text { contribute to the stability of the lives of the citizens and to the sound development of } \\
\text { the national economy. } \\
\text { The IBA defines the powers and responsibilities of the FSA with respect to insurance } \\
\text { supervision. The IBA gives various powers to the Prime Minister, but the IBA and the } \\
\text { Order for Enforcement of the Insurance Business Act delegate most of these powers to }\end{array}$ \\
\hline
\end{tabular}




\begin{tabular}{|c|c|}
\hline & $\begin{array}{l}\text { the Commissioner of the FSA. The exceptions are powers delegated to the Minister for } \\
\text { Financial Services, which relate to licensing, cancellation of a license, approval of } \\
\text { establishment of insurance holding companies, and approval of establishment of the } \\
\text { Policyholder Protection Corporations. The IBA gives the FSA adequate powers to } \\
\text { conduct insurance supervision. } \\
\text { The responsibilities of the FSA include planning with respect to the insurance } \\
\text { regulatory framework. The FSA takes action or proposes changes in legislation where } \\
\text { it identifies aspects of the framework that compromise the achievement of supervisory } \\
\text { objectives. For example, it issued an administrative order and revised the Supervisory } \\
\text { Guideline to deal with weaknesses in claims payment practices. It also proposed } \\
\text { changes needed to support group-wide supervision. }\end{array}$ \\
\hline Assessment & Observed. \\
\hline Comments & $\begin{array}{l}\text { As a consolidated supervisor, the FSA has been able to take advantage of economies } \\
\text { of scale. However, the large part of the insurance market served by cooperatives is } \\
\text { supervised by independent departments within several ministries. This could } \\
\text { potentially cause challenges of resourcing and might make it difficult to achieve } \\
\text { consistency of supervision. } \\
\text { To help ensure that the objectives of insurance supervision are pursued in a consistent } \\
\text { manner with respect to all parts of the Japanese insurance sector, the FSA and the } \\
\text { responsible ministries should consider establishing a process that would facilitate the } \\
\text { regular exchange of views on the objectives of insurance supervision and the manner } \\
\text { in which those objectives might be achieved. Alternatively, the government might } \\
\text { consider centralizing insurance supervision with the FSA. }\end{array}$ \\
\hline ICP 2 & $\begin{array}{l}\text { Supervisor } \\
\text { The supervisor, in the exercise of its functions and powers: } \\
\text { - Is operationally independent, accountable and transparent; } \\
\text { - Protects confidential information; } \\
\text { - Has appropriate legal protection; } \\
\text { - Has adequate resources; and } \\
\text { - Meets high professional standards. }\end{array}$ \\
\hline Description & $\begin{array}{l}\text { The FSA is an external organ of the Cabinet Office, headed by a Commissioner and } \\
\text { accountable to the Minister for Financial Services. Its responsibilities include the } \\
\text { supervision of the insurance, banking, and securities sectors. Its organization is } \\
\text { governed by the Law on the Establishment of the Cabinet Office. The FSA is } \\
\text { structured on a functional basis, with three Bureaus: Planning and Coordination, } \\
\text { Inspection, and Supervisory, each of which deals with all three sectors. The FSA has } \\
\text { an internal audit function. } \\
\text { Three other activities also fall within the responsibility of the FSA: } \\
\text { - The Securities and Exchange Surveillance Commission (SESC), which } \\
\text { consists of } 6 \text { divisions that conduct daily market surveillance, inspections of } \\
\text { financial instruments firms, etc., administrative monetary penalties }\end{array}$ \\
\hline
\end{tabular}


investigations, disclosure documents inspections and criminal investigations into securities fraud;

- The Certified Public Accountants and Auditing Oversight Board (CPAAOB), which conducts examinations of the "quality control review" by the Japanese Institute of Certified Public Accountants and inspections on audit firms, implements the Certified Public Accountants Examinations, and deliberates matters concerning disciplinary actions against Certified Public Accountants and audit firms; and

- The Financial System Council, which inquires into and deliberates on domestic financial systems and other issues in response to consultations with the Prime Minister, the Commissioner of the FSA, or the Minister of Finance.

There were 1,537 staff members as of March 2011, including the Commissioner of the FSA, the Chairperson and two Commissioners of the SESC, and the Chairperson and Full-time Commissioner of the CPAAOB.

The Supervisory Bureau is responsible for off-site analysis. It includes separate units for life and nonlife insurance within the Insurance Business Division. There is a separate unit for the supervision of Japan Post Insurance and Japan Post Bank. There is a lead person responsible for each insurer, who manages the FSA's ongoing relationship with the insurer. There is also an anti-money laundering (AML) team within the Supervisory Bureau.

The Inspection Bureau is responsible for onsite inspections. It includes five inspection units, some of which focus on insurance, along with teams that specialize in risk management and accounting and support the inspection process for both insurance and banking. Staff is assigned to inspection teams as inspections occur, rather than being assigned to specific insurers on an ongoing basis.

The Planning and Coordination Bureau is responsible for matters such as general coordination-including internationally, policy and legal, regulatory planning, corporate accounting and disclosure, and financial markets. There is an insurance unit within the Planning Division.

Staff of the Supervisory and Inspection Bureaus communicate regularly in the supervision of insurers. Supervisory concerns are communicated upward within the FSA, facilitating decision-making and action in dealing with concerns related to a particular insurer.

Procedures regarding the appointment and dismissal of the Commissioner of the FSA are set out in the National Public Service Act. The Commissioner is appointed and can be dismissed by the Prime Minister, who in such matters would take advice from the Minister for Financial Services. There has been no case in which the Commissioner has been dismissed, but if this were to occur the law does not require that the reasons be publicly disclosed.

As noted under ICP 1, the IBA gives various powers to the Prime Minister, but these powers are delegated to either the Commissioner of the FSA or the Minister for Financial Services. The LEFSA provides that the FSA may request the cooperation of the heads of relevant government bodies, where deemed necessary in the course of fulfilling its duties. For example, cooperation with the Ministry of Finance would be necessary if the national budget would be affected by the resolution of a failed insurer. Judicial authority is separated from the administrative branches of government by the 
Japanese Constitution.

Except for licensing matters, which require the decision of the Minister for Financial Services, the FSA has been free to perform its supervisory responsibilities without government, political, and industry interference. With respect to licensing, the FSA indicates that there have been no cases in which the Minister for Financial Services has decided contrary to its recommendations.

The annual budget of the FSA must be approved by the Diet, after first being approved by the Minister for Financial Services and the Ministry of Finance. In recent years, the budget and staffing levels of the FSA have been increasing, while those of other government departments have been reduced. Nevertheless, the budget approved by the Diet has sometimes been less than requested by the FSA. Within its overall budget, the FSA is free to allocate resources as it deems necessary.

Regulatory requirements are set out in Laws, Orders, Ordinances, and Ministerial Notes. They are further elaborated in Supervisory Guidelines developed by the FSA, which describe its approach to supervision and expectations against which it will assess the activities of industry participants. All of these documents are publicly available on the FSA's website, along with its onsite Inspection Manuals.

In addition, the FSA has a no-action letter system, under which any financial institution may seek an advance opinion from the FSA about the acceptability of a new business in which it is planning to engage. Inquiries are generally answered by the FSA within 30 days, and both inquiries and responses are publicly available on the FSA's website within 30 days thereafter.

The FSA relies on the process of management review to ensure consistent and equitable application of regulatory requirements and supervisory procedures. Such review occurs when matters arise that require management approval. The FSA does not have a supervisory rating system or a peer review process, although the consistency and equity of the application of requirements and procedures would be subject to further review in connection with internal audits.

Regulatory requirements and supervisory procedures are reviewed regularly, and the FSA annually publishes policies for supervision and onsite inspection. The FSA consults with industry and the public on proposed changes, as required by the Administrative Procedures Act.

The FSA publishes information about its own role and how it performs its duties in its annual Basic Plan for Policy Evaluations of the FSA, as required by the Government Policy Evaluations Act, and its annual report. The annual report also discusses developments in the insurance sector. The FSA does not publish financial or statistical information about insurers and intermediaries.

Any person may object to supervisory decisions taken by the FSA, in accordance with procedures described in the Administrative Appeal Act. Judicial review is also available in accordance with the State Redress Act or the Administrative Case Litigation Act. When an adverse decision, such as the cancellation of a license, is to be imposed, the affected entity generally has the opportunity to make a statement. However, such an opportunity may not be given in cases where, for example, urgent action is required to protect the public interest. A person may request a court to stay the execution of a supervisory action.

The National Public Service Act requires the FSA and its current and former staff to 
protect the confidentiality of information and prescribes penalties for wrongful disclosure. The FSA carefully protects confidential information and denies any request to release such information, other than when required by law, or when requested by another supervisor who has a legitimate supervisory interest and the ability to uphold the confidentiality of the requested information. The FSA seeks the consent of a foreign supervisor before disclosing confidential information that it provided to the FSA. Current and former staff of the FSA cannot be legally compelled to disclose confidential information in the absence of the consent of the Commissioner. The Commissioner can refuse consent, although such refusal can be appealed to the court.

The National Public Service Act protects current and former staff of the FSA against lawsuits. The FSA itself can be sued, but cannot be held liable unless it exercised power illegally. In accordance with the State Redress Law, if a current or former staff member of the FSA exercising power illegally causes damage to a person the FSA would be liable to compensate the injured party for the damage. However, in such a case, if the damage was caused intentionally or by gross negligence, the FSA would be able to seek compensation from the staff member.

As mentioned above, the budget and staffing levels of the FSA have been increasing, while those of other government departments have been reduced. Its staff includes professionals such as actuaries, accountants, and lawyers, as well as other individuals with industry experience. Nevertheless, there are indications that resources are inadequate to enable the FSA to conduct supervision in a fully-effective manner. For example, the frequency of onsite inspections is insufficient (see ICPs 9 and 18), and the number of persons in the Supervision Bureau is small relative to the number and size of the insurers supervised.

The FSA has a training program that includes internal courses and external training, including secondment of staff to industry. The training covers a wide range of subjects, including those that are insurance-related (such as supervision, onsite inspection, and actuarial matters), financial-related (risk management, derivatives, and accounting) and general in nature (management, English, and ethics).

The FSA does not make use of outside experts. It has the ability to do so, but they would either have to be retained through a tender or hired as staff for a limited period, such as two years.

The FSA has a code of ethics, which is based on the National Public Service Ethics Act. It includes conflict of interest rules, such as prohibiting investments in entities supervised by the department in which an individual works. Breaches of the code of ethics are subject to disciplinary action. The FSA requires all staff to attend a course on ethics.

Assessment Partly observed.

Comments While currently there are no indications of political interference in the supervision of insurers, the legal framework governing the FSA contains elements that could undermine the independence and capacity of the supervisor. For example, the budget must be approved by appointed and elected government officials, which leaves it exposed to cutbacks for financial or political reasons. Consideration should be given to having the FSA financed in a manner that does not involve negotiation of its budget, such as by legally-enforceable levies on the industry, which could be useful in 


\begin{tabular}{|c|c|}
\hline & $\begin{array}{l}\text { strengthening both its independence and its resources. } \\
\text { The FSA has been strengthening its insurance regulatory framework and is improving } \\
\text { the tools used for supervisory assessment. The FSA should build on this by completing } \\
\text { the development of a methodology for risk-rating insurers, adopting a structured } \\
\text { system for the internal review of risk assessments, and further increasing the level of } \\
\text { resources to enable inspections to be performed more frequently-particularly for the } \\
\text { largest insurers. } \\
\text { Industry participants appreciate the proactive manner in which the FSA consults on } \\
\text { regulatory and supervisory changes. The FSA expects industry participants to act in } \\
\text { accordance with the guidance provided by both the Supervisory Guideline and the } \\
\text { Inspection Manuals. However, the manner in which the expectations are expressed } \\
\text { could affect both their enforceability and their transparency. The FSA should consider } \\
\text { making some expectations into requirements within the IBA or secondary legislation } \\
\text { and communicate important expectations through the Supervisory Guideline rather } \\
\text { than the Inspection Manuals. } \\
\text { It is important that the public have ready access to financial and statistical information } \\
\text { about insurers and intermediaries. Japanese industry associations publish industry- } \\
\text { wide information and information about individual insurers and insurance groups is } \\
\text { available on their respective websites. However, it would be better for the public to be } \\
\text { able to obtain both industry-wide and entity-specific information from a single, reliable, } \\
\text { and consistent source. This would facilitate the ability of others to perform analyses } \\
\text { and contribute to market discipline. The FSA should make information about the } \\
\text { industry, individual insurers, insurance groups, and intermediaries available on its } \\
\text { website. } \\
\text { Many supervisors make use of outside experts to improve their effectiveness, for } \\
\text { example, by contracting with persons having specialized expertise in an emerging area } \\
\text { of industry activity. The FSA should consider the possibility of using outside experts to } \\
\text { supplement its staff resources. }\end{array}$ \\
\hline ICP 3 & $\begin{array}{l}\text { Information Exchange and Confidentiality Requirements } \\
\text { The supervisor exchanges information with other relevant supervisors and authorities } \\
\text { subject to confidentiality, purpose and use requirements. }\end{array}$ \\
\hline Description & $\begin{array}{l}\text { The IBA empowers the FSA to obtain information from a wide range of entities related } \\
\text { to insurers, including subsidiaries, insurance holding companies and their subsidiaries, } \\
\text { and major shareholders of insurers. This power is not restricted to regulated entities. } \\
\text { As an integrated supervisor, the FSA can also obtain information on banks and } \\
\text { securities firms. } \\
\text { The LEFSA empowers the FSA to exchange information with other supervisors and } \\
\text { authorities. This includes both foreign authorities and other local authorities, such as } \\
\text { the BOJ, the Financial Investigations Unit, and the ministries responsible for } \\
\text { supervising cooperative insurers. } \\
\text { The FSA is a signatory to the IAIS Multilateral Memorandum of Understanding } \\
\text { (MMoU). It also has bilateral agreements with the supervisors in foreign jurisdictions } \\
\text { where Japanese insurers have material operations. } \\
\text { The FSA proactively provides information in cases where supervisory actions might }\end{array}$ \\
\hline
\end{tabular}




\begin{tabular}{|c|c|}
\hline & $\begin{array}{l}\text { affect group entities. It also provides and receives information in relation to situations } \\
\text { that might affect the Japanese operations of foreign insurers and the foreign } \\
\text { operations of Japanese insurers, such as natural catastrophes. } \\
\text { The existence of an agreement or understanding on information exchange is not a } \\
\text { prerequisite for the exchange of information. In the absence of such an agreement, the } \\
\text { FSA checks the confidentiality regime of the jurisdiction before responding to a foreign } \\
\text { supervisor's request for confidential information. } \\
\text { The law does not require strict reciprocity and this issue has not arisen in practice. } \\
\text { The FSA requires a foreign supervisor to obtain its prior consent before passing } \\
\text { confidential information provided by the FSA on to a third party. Consent is given if the } \\
\text { FSA is satisfied that the information will remain confidential. } \\
\text { When requesting information from a foreign supervisor, the FSA specifies how the } \\
\text { information will be used and uses the information only for the purpose specified. When } \\
\text { the FSA is required to pass on confidential information received from a foreign } \\
\text { supervisor to a third party in a legally-binding manner, it seeks the prior consent of the } \\
\text { foreign supervisor. If such prior consent is not obtained, the FSA takes all available } \\
\text { actions to resist the third party's request (see ICP 2). }\end{array}$ \\
\hline Assessment & Observed. \\
\hline Comments & $\begin{array}{l}\text { The positive response to specific requests from foreign supervisors could be enhanced } \\
\text { by a more proactive exchange of information with all relevant supervisors. The FSA } \\
\text { should consider expanding its distribution list of relevant supervisors that might be } \\
\text { interested in various types of information. } \\
\text { The exchange of information with a foreign supervisor could be delayed if the FSA has } \\
\text { not previously checked the confidentiality regime of the foreign jurisdiction. To } \\
\text { minimize the risk of such delays and facilitate proactive, two-way exchanges of } \\
\text { information, the FSA should check the confidentiality regimes of all relevant home and } \\
\text { host jurisdictions before a specific need arises. }\end{array}$ \\
\hline ICP 4 & $\begin{array}{l}\text { Licensing } \\
\text { A legal entity which intends to engage in insurance activities must be licensed before it } \\
\text { can operate within a jurisdiction. The requirements and procedures for licensing must } \\
\text { be clear, objective and public, and be consistently applied. }\end{array}$ \\
\hline Description & $\begin{array}{l}\text { Generally, entities must be licensed to engage in insurance activities in Japan. The } \\
\text { IBA requires insurers to be licensed. However, it identifies some insurance-like } \\
\text { activities as being outside its scope, including captives and other forms of insurance- } \\
\text { like business transacted within certain closed groups, such as by labor unions with } \\
\text { their members, neither of which is subject to licensing or supervision. The insurance } \\
\text { activities of cooperatives are subject to other Acts and are licensed and supervised by } \\
\text { the government ministries responsible for the relevant sectors. A supplementary } \\
\text { provision of the IBA, which is subject to review within five years after coming into effect } \\
\text { in } 2011 \text {, enables small community organizations to continue to engage in "approved } \\
\text { specific insurance business." }\end{array}$ \\
\hline
\end{tabular}


The IBA requires domestic insurers to be either stock companies or mutual companies. Foreign insurers can operate either through subsidiaries or branches.

The IBA provides for two types of license: life insurance and nonlife insurance. An insurer cannot hold both types of license, although both life and nonlife insurers are permitted to underwrite "third sector" business, which includes accident and sickness and travel insurance. Insurers are permitted to assume reinsurance; reinsurance-only companies are licensed as nonlife insurers, but can also assume life reinsurance.

The IBA provides that a person who conducts insurance business without a license shall be punished by imprisonment with work for not more than three years or a fine of not more than $¥ 3$ million, or both.

The application procedure and criteria for licensing are set out in the IBA and the Order for the Enforcement of the Insurance Business Act (OEIBA). Licensing criteria include having: a financial basis to conduct insurance business soundly and efficiently; a good business plan; knowledge, experience, and social credibility; products that will adequately protect policyholders; and reasonable and proper calculation procedures for insurance premiums and technical provisions. The amount of capital (or funds of a mutual insurer) is required to be at least $¥ 1$ billion. The OEIBA requires that the future business plans of a life insurer would be expected to generate net profit or net surplus in a single business year within ten years after commencement of its business; the relevant period is five years for a nonlife insurer. The FSA reviews the governance framework of an applicant and considers, for example, whether the group structure and group governance framework are transparent.

As noted under ICP 1, the Prime Minister has delegated the powers of licensing and cancellation of a license to the Minister for Financial Services. The FSA submits its licensing recommendations to the Minister for Financial Services, and indicates that there have been no cases in which the Minister has decided contrary to its recommendations.

Where a foreign insurer is seeking to establish a branch or subsidiary in Japan, the IBA requires that it submit a certificate from its home supervisor confirming that its operation in Japan has been lawfully established and that it is lawfully transacting business in its home country that is similar to the insurance business it intends to conduct in Japan. The FSA generally communicates with the home supervisor before recommending the issuance of a license.

The IBA prohibits insurers from conducting cross border insurance activities without a physical presence in Japan, except for certain types of contracts, such as reinsurance. It also requires a person that intends to apply to a foreign insurer without a branch office in Japan for insurance pertaining to any persons with an address or residence in Japan or property located in Japan to obtain the permission of the Commissioner of the FSA. The FSA would, if necessary, consult the home supervisor in such cases.

The OEIBA indicates that the FSA shall endeavor to render the disposition in response to an application for licensing within 120 days of its receipt. In practice, applications are generally dealt with within three months.

No license is issued to an applicant who does not meet the licensing criteria stipulated by the IBA. The IBA provides that the license may, when and to the extent necessary for the public interest, be granted with conditions. 


\begin{tabular}{|c|c|c|c|}
\hline & \multicolumn{3}{|c|}{$\begin{array}{l}\text { Where a license denied or is issued with conditions, the FSA explains the reasons. } \\
\text { Licenses state their scope, in terms of whether they are for life insurance or nonlife } \\
\text { insurance. Insurers can underwrite any class of insurance covered by the type of } \\
\text { license that they hold, as long as it is described in the plan of business reviewed by the } \\
\text { FSA. Therefore, an insurer that wants to expand into an additional class of insurance } \\
\text { must submit a revised plan of business to the FSA and obtain its approval of the new } \\
\text { products. Insurers that underwrite unapproved products are subject to penalties under } \\
\text { the IBA. }\end{array}$} \\
\hline Assessment & \multicolumn{3}{|l|}{ Observed. } \\
\hline Comments & \multicolumn{3}{|c|}{$\begin{array}{l}\text { Although it is clear that an insurer is licensed for either life insurance or nonlife } \\
\text { insurance, the specific classes of insurance that the FSA has approved the insurer to } \\
\text { underwrite are not publicly disclosed. Such information can be useful to consumers } \\
\text { and intermediaries. The FSA should consider publishing information regarding the } \\
\text { classes of insurance each insurer has been approved to underwrite. } \\
\text { As commented under ICP 9, the legislation should be amended to require foreign } \\
\text { branches to submit audited financial information, so that this requirement is fully } \\
\text { transparent to those seeking a license. }\end{array}$} \\
\hline ICP 5 & \multicolumn{3}{|c|}{$\begin{array}{l}\text { Suitability of Persons } \\
\text { The supervisor requires Board Members, Senior Management, Key Persons in Control } \\
\text { Functions and Significant Owners of an insurer to be and remain suitable to fulfill their } \\
\text { respective roles. }\end{array}$} \\
\hline \multirow[t]{11}{*}{ Description } & \multicolumn{3}{|c|}{$\begin{array}{l}\text { The IBA and regulations identify which persons must meet suitability requirements. } \\
\text { There are differences, which depend on the board structure adopted by the insurer } \\
\text { (see ICP 7), as indicated in the following table: }\end{array}$} \\
\hline & Role & $\begin{array}{l}\text { Advisory Board } \\
\text { Structure }\end{array}$ & $\begin{array}{l}\text { Monitoring Board } \\
\text { Structure }\end{array}$ \\
\hline & Major Shareholder & Yes & Yes \\
\hline & Full-time Director & Yes & Yes \\
\hline & Part-time Director & No $1 /$ & No $1 /$ \\
\hline & $\begin{array}{l}\text { Executive Officer (who is not a } \\
\text { Director) }\end{array}$ & No & Yes \\
\hline & Full-time Corporate Auditor & No $1 /$ & Not applicable \\
\hline & Part-time Corporate Auditor & No $1 /$ & Not applicable \\
\hline & Appointed Actuary & Yes & Yes \\
\hline & External Auditor & Yes & Yes \\
\hline & \multicolumn{3}{|c|}{$\begin{array}{l}\text { 1/ Directors and corporate auditors are, however, subject to the requirement of the Companies Act in terms } \\
\text { of a criminal record, which provides that a person who has been sentenced to a penalty for having violated } \\
\text { the Companies Act or other relevant laws or regulations, and for whom two years have not elapsed since the } \\
\text { day on which the execution of the sentence was completed or the sentence no longer applied, cannot hold } \\
\text { such positions. }\end{array}$} \\
\hline
\end{tabular}


The above table also applies in respect of the directors, executive officers, and auditors of an insurance holding company.

The IBA requires major shareholders to have sufficient understanding of the public nature of the insurance business and sufficient social credibility. A major shareholder must not create the risk of impairing the sound and appropriate management of the business of the insurer in which it holds voting rights.

The IBA requires an insurance holding company to have good financial prospects and its senior managers to have the knowledge and experience that will enable the holding company to carry out the business management of its subsidiary insurer appropriately and fairly, as well as sufficient social credibility. A person who has become subject to bankruptcy proceedings and has not had his rights restored may not be appointed as a director, executive officer, or auditor of an insurance holding company.

The IBA requires full-time directors of an insurer, and executive officers of an insurer with a monitoring board structure, to have the knowledge and experience to carry out business management of an insurance company appropriately, fairly and efficiently, as well as sufficient social credibility. It also specifies criteria, such as criminal history, which would make a person ineligible.

The IBA does not prescribe suitability requirements for corporate auditors. The Japan Association of Corporate Auditors has developed voluntary selection criteria for persons serving in this role.

The IBA requires appointed actuaries to be full members of the Institute of Actuaries of Japan with at least five years of actuarial experience in the life insurance or nonlife insurance sector, depending on the type of insurer (or at least seven years of actuarial experience without regard to sector). External auditors must be members of the Japanese Institute of Certified Public Accountants and not meet specified criteria for disqualification; they are not subject to a minimum experience requirement.

The IBA and the OEIBA require a person to obtain the advance approval of the FSA before becoming a major shareholder. The IBA requires major shareholders to notify the FSA when they become a major shareholder or cease to hold voting rights that would meet the threshold for being considered a major shareholder. It also requires an insurance holding company to notify the FSA when it becomes a holding company of an insurer, ceases to be an insurance holding company, or intends to change the amount of capital. The FSA has the authority to conduct onsite inspections of major shareholders and to require them to submit reports or materials. The FSA can take measures, such as requiring business improvements or cancelling its approval, if a major shareholder fails to meet the suitability requirements.

The OEIBA requires an insurer to notify the FSA when any person has assumed or left a position as a full-time director, an executive officer, a corporate auditor, or the appointed actuary. It also requires notification where it has come to the knowledge of the insurer that any deplorable event has occurred to the insurer or a subsidiary.

Through off-site monitoring, such as interviews, and onsite inspection, the FSA reviews whether persons meet the suitability criteria on an ongoing basis. If not, the insurer or insurance holding company is subject to administrative action. Such action might include an order to replace an unsuitable person, an order to improve the selection process, an order to fully or partially suspend business operations, or cancellation of the license. 


\begin{tabular}{|c|c|}
\hline Assessment & Largely observed. \\
\hline Comments & $\begin{array}{l}\text { Suitability requirements should formally apply to all persons who hold have key roles in } \\
\text { the governance and operation of an insurer. This reinforces the need for insurers to } \\
\text { select suitable persons for such roles. It also strengthens the supervisor's ability to } \\
\text { take corrective action. Currently, there are some gaps in the scope of suitability } \\
\text { requirements. The legislation should be revised to extend the application of suitability } \\
\text { requirements to part-time directors, corporate auditors, and all executive officers. } \\
\text { In some jurisdictions, legislation permanently prohibits persons who have been } \\
\text { convicted of financial crimes from holding key roles in the governance and operation of } \\
\text { an insurer. This strengthens the ability of the supervisor to declare such persons to be } \\
\text { unfit. The FSA should consider seeking an amendment to legislation to strengthen its } \\
\text { ability to disqualify persons who have been convicted of financial crimes from holding } \\
\text { key roles in the governance and operation of an insurer. }\end{array}$ \\
\hline ICP 6 & $\begin{array}{l}\text { Changes in Control and Portfolio Transfers } \\
\text { Supervisory approval is required for proposals to acquire significant ownership or an } \\
\text { interest in an insurer that results in that person (legal or natural), directly or indirectly, } \\
\text { alone or with an associate, exercising control over the insurer. The same applies to } \\
\text { portfolio transfers or mergers of insurers. }\end{array}$ \\
\hline Description & $\begin{array}{l}\text { The IBA indicates that a major shareholder is a shareholder who could have influence } \\
\text { on the management of an insurer. A person that holds } 20 \text { percent or more of the voting } \\
\text { rights of an insurer is a major shareholder, as is a person that holds } 15 \text { percent or } \\
\text { more of the voting rights accompanied with significant influence over an insurer. The } \\
\text { thresholds are based on direct, indirect, and joint shareholdings. Significant influence } \\
\text { includes the power to appoint or remove directors. } \\
\text { The OEIBA requires any person who holds more than } 5 \text { percent of the voting rights of } \\
\text { an insurer or an insurance holding company to notify the FSA of such holding. The IBA } \\
\text { and the OEIBA require a person who intends to become a holder of } 15 \text { percent or } \\
\text { more of the voting rights of an insurer or an insurance holding company to obtain } \\
\text { authorization to do so from the FSA. The FSA is required to make decisions regarding } \\
\text { requests to approve major shareholdings within } 30 \text { days and to acquire subsidiaries } \\
\text { within three months. Approvals can be subject to conditions. } \\
\text { The IBA requires any person who holds more than } 5 \text { percent of the voting rights of an } \\
\text { insurer to notify the FSA of every increase or decrease of } 1 \text { percent or more in the } \\
\text { person's voting rights. This enables the FSA to identify and monitor a potential change } \\
\text { in control at an early stage. } \\
\text { Whether a shareholder is regarded as a major shareholder does not depend on its } \\
\text { location. If it is located outside Japan, the FSA coordinates with the foreign authorities, } \\
\text { where relevant and necessary. } \\
\text { The FSA applies the same criteria when assessing applications for approval of major } \\
\text { shareholders or insurance holding companies, regardless of whether such applications } \\
\text { are received during the licensing process or thereafter. } \\
\text { The FSA requires major shareholders to submit financial statements annually. }\end{array}$ \\
\hline
\end{tabular}




\begin{tabular}{|c|c|}
\hline & 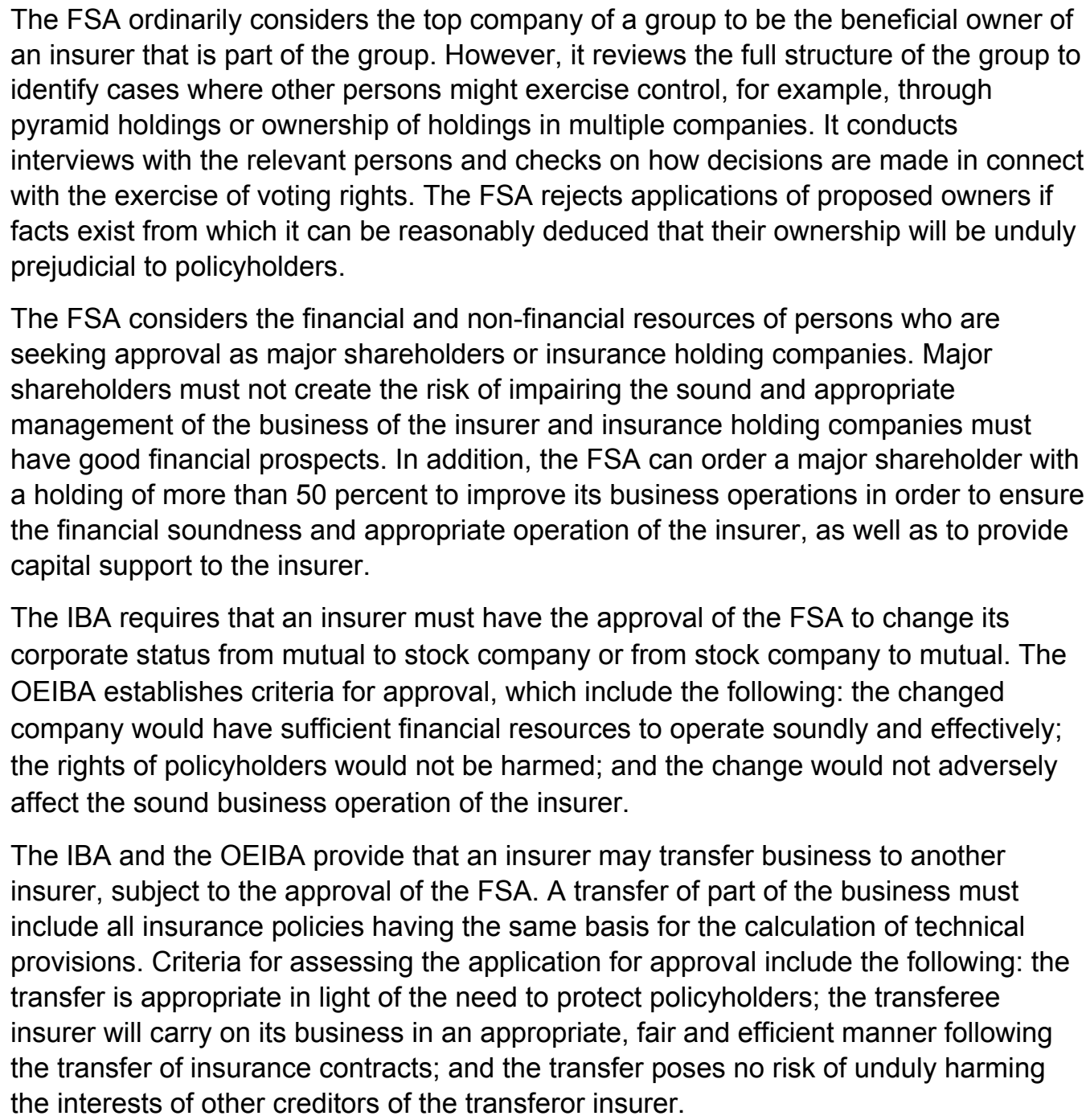 \\
\hline Assessment & Observed. \\
\hline Comments & $\begin{array}{l}\text { The experience gained through the significant number of portfolio transfers in the late } \\
\text { 1990s and early 2000s has been reflected both in the legal framework and in practice. }\end{array}$ \\
\hline ICP 7 & $\begin{array}{l}\text { Corporate Governance } \\
\text { The supervisor requires insurers to establish and implement a corporate governance } \\
\text { framework which provides for sound and prudent management and oversight of the } \\
\text { insurer's business and adequately recognizes and protects the interests of } \\
\text { policyholders. }\end{array}$ \\
\hline Description & $\begin{array}{l}\text { The Companies Act and the IBA allow Japanese insurers to choose either of two } \\
\text { corporate governance structures: the advisory board structure or the monitoring board } \\
\text { structure. Most insurers use the advisory board structure, which is the traditional } \\
\text { structure that has been used in Japan. }\end{array}$ \\
\hline
\end{tabular}


- Under the advisory board structure, most directors are also executive officers, who are assigned specific areas of responsibility within the company. Others are part-time, outside directors. Monitoring of the actions of the board of directors and the operation of the company is performed by a board of corporate auditors, which must have three or more members, the majority of which must be from outside the company. Corporate auditors are neither directors nor staff of the company, and at least one-half of them must be from outside the company. Generally, the outside corporate auditors work part-time, while the full-time corporate auditors are former executive officers or senior employees of the company. Part-time corporate auditors often have special expertise, such as accounting or law.

- Under the monitoring board structure, the board of directors appoints executive officers and monitors their conduct. The board of directors must establish at least three committees: compensation, auditing, and nomination. Each committee must have at least three members, the majority of which must be outside directors. In the case of the auditing committee, no member may be an officer or employee of the company or its subsidiaries.

Individuals are considered to be "outside" a company if they are not a current or previous executive director, officer, manager, or employee of the company or any of its subsidiaries.

The Supervisory Guideline indicates that an insurer's board of directors is expected to articulate a corporate management policy for achieving the insurer's overall targets, as well as a corporate management plan and a risk management policy that is aligned with it. The board of directors is expected to communicate these policies and plans throughout the company and to review them periodically.

The IBA and the OEIBA require the board of directors to develop systems to ensure that directors execute their duties efficiently in accordance with laws and regulations and that employees execute their duties in accordance with laws and regulations, to oversee senior management, and to develop systems to ensure effective reporting from directors to corporate auditors and the effective performance of audits by corporate auditors. The FSA expects the board of directors to ensure that there are terms of reference for the board, its committees, and senior executive positions. The Supervisory Guideline indicates that the board of directors should establish a system that enables the internal audit division to fully perform its functions, including ensuring its independence.

The IBA requires directors engaging in the ordinary business of an insurer to have the knowledge and experience to conduct management of an insurance company appropriately, fairly and efficiently, and have sufficient social credibility. As noted under ICP 5, this requirement does not formally apply to part-time, outside directors. However, the Supervisory Guideline indicates that directors should have sufficient knowledge and experience concerning the insurer's business operations, compliance, and risk management to support the sound and appropriate management of the operations.

The IBA and the OEIBA require the board of directors to develop systems to ensure that directors execute their duties efficiently in accordance with laws and regulations.

The Companies Act states that directors owe fiduciary duties of care and loyalty to their company, and are prohibited from making management decisions that would 
undermine the interests of policyholders, who are creditors of the company. It also prohibits them from using their positions in order to gain personal advantage or in ways that would be detrimental to policyholders. The Companies Act further provides that where a director engages, or is likely to engage, in an act outside the scope of the purpose of a company, or other acts in violation of laws and regulations or the articles of incorporation, and if such act is likely to cause substantial detriment to the company, the corporate auditors may demand that the director cease such act. The Supervisory Guideline indicates that insurers should have policies on conflicts of interest and that the directors should take the initiative in making sincere efforts to ensure legal compliance.

As mentioned above, the Supervisory Guideline indicates that the board of directors is expected to establish and communicate a risk management policy. It is also expected to periodically report on the status of risks, check the effectiveness of internal audit, approve internal audit policies and fundamental items of internal audit plans, and take appropriate actions with respect to the results of internal audits.

The Supervisory Guideline indicates that the board of directors should develop a system to ensure an appropriate design and management of the remuneration system. It should also check that the level of the total remuneration amount does not have a material impact on the future soundness of the insurance company, maintain close cooperation with risk management divisions in designing and managing the remuneration system, check that remuneration is not linked excessively to the achievement of short-term profits, and ensure that remuneration for employees in risk management divisions is determined independently from the remuneration for other business divisions. Such expectations are also applicable with respect to officers and employees who could have a material impact on risk-taking by the whole company, for an insurer that has foreign operations. The Companies Act requires remuneration for directors and corporate auditors to be approved at a general shareholders meeting. For listed companies, remuneration for officers whose annual remuneration exceeds $¥ 100$ million must be disclosed, but in fiscal 2010 , there was no officer of a listed Japanese insurer whose remuneration was subject to disclosure.

The Companies Act requires listed companies to establish an internal control system to ensure the appropriateness of the financial reporting process. The Financial Instruments and Exchange Act requires a representative of the company to confirm the appropriateness of this internal control system. Through onsite inspection, the FSA checks whether the director or senior executive responsible fully understands the importance of the management of financial soundness and actuarial matters and ensures that appropriate policies and systems are developed based on that understanding. The IBA requires insurers to appoint external auditors, whose responsibilities are specified by the Companies Act, the IBA, and the OEIBA.

Insurers are required to publicly disclose information regarding their governance (see ICP 20). They are also required to provide information on governance to the FSA, for example through regular off-site interviews. The FSA conducts comprehensive off-site interviews with large insurers at least semi-annually and with other insurers at least annually. Through these interviews, it obtains information about corporate management policies, governance structure, the eligibility of directors, methods of business performance evaluation, the status of shareholders, management challenges, business strategies and various risks involved therein, as well as the exercise of the functions of the board of directors and the board of corporate auditors. The FSA interviews the internal audit division to obtain information about the internal audit 


\begin{tabular}{|c|c|}
\hline & $\begin{array}{l}\text { system and the status of the implementation of recommendations made by internal } \\
\text { audit. As necessary, the FSA also interviews corporate auditors and outside directors. } \\
\text { The Supervisory Guideline indicates that the board of directors should cultivate a } \\
\text { corporate culture that emphasizes the importance of governance and should examine } \\
\text { the appropriateness and effectiveness of governance. Senior management is expected } \\
\text { to establish risk management, compliance, and customer protection systems. The FSA } \\
\text { reviews these systems, as well as the information provided by senior management to } \\
\text { the board of directors. } \\
\text { Through both off-site monitoring-including interviews of directors and executive } \\
\text { officers-and onsite inspection, the FSA assesses the appropriateness of governance. } \\
\text { If concerns arise, the FSA takes various actions, such as requiring insurers to improve } \\
\text { their governance and operational practices and to submit reports or materials } \\
\text { concerning their status. }\end{array}$ \\
\hline Assessment & Largely observed. \\
\hline Comments & $\begin{array}{l}\text { Corporate governance in Japan has improved, but independence remains weak. While } \\
\text { a few insurers have a board structure with a clear segregation between board } \\
\text { members and senior management in place, the majority of the insurers and insurance } \\
\text { holding companies maintain the traditional structure of a board largely comprised of } \\
\text { senior management overseen by an audit board. However, the board of corporate } \\
\text { auditors has limited powers; for example, it cannot dismiss directors or call for a } \\
\text { shareholders meeting, which could compromise the timeliness and effectiveness of its } \\
\text { interventions. Its work is largely performed by full-time members who were previously } \\
\text { part of management, and fit and proper requirements under the IBA do not apply to } \\
\text { corporate auditors and apply only to a limited extent to part-time directors. } \\
\text { Also, many insurers-even those with a monitoring board structure-have few outside } \\
\text { directors on their boards. As well as improving oversight, a larger proportion of outside } \\
\text { directors could be useful in providing management with additional, independent views } \\
\text { on business matters. Furthermore, the definition of "outside" is less restrictive than it } \\
\text { might be; for example, it does not exclude the spouse of a senior executive. } \\
\text { The corporate governance and suitability requirements should be revised to strengthen } \\
\text { independent oversight, which will reinforce the supervisory efforts of the FSA. } \\
\text { Many important aspects of corporate governance are dealt with in the Supervisory } \\
\text { Guideline, rather than in legislation. As indicated under ICP } 2 \text {, the FSA should consider } \\
\text { making some of these expectations into legally-binding requirements under the IBA or } \\
\text { secondary legislation. }\end{array}$ \\
\hline ICP 8 & $\begin{array}{l}\text { Risk Management and Internal Controls } \\
\text { The supervisor requires an insurer to have, as part of its overall corporate governance } \\
\text { framework, effective systems of risk management and internal controls, including } \\
\text { effective functions for risk management, compliance, actuarial matters, and internal } \\
\text { audit. }\end{array}$ \\
\hline Description & $\begin{array}{l}\text { The Companies Act and the IBA require insurers to have internal controls. The } \\
\text { Supervisory Guideline reinforces this, indicating that insurers should develop effective } \\
\text { systems of risk management and internal controls, including establishing an internal }\end{array}$ \\
\hline
\end{tabular}


audit division which is independent from audited divisions and has the power to report directly to the board of directors. It also indicates that insurers should maintain financial soundness and appropriate business operations, which should include risk management, compliance, and management of actuarial matters.

The Supervisory Guideline indicates that insurers should specify a division responsible for comprehensive risk management, appoint the head of the division and a senior officer in charge, and develop a system to ensure that the status of comprehensive risk management for the whole company is reported to the board of directors in a timely and appropriate manner. The division responsible for comprehensive risk management is expected to maintain functional independence from the operational divisions.

The IBA requires each insurer to have an appointed actuary. The board of directors is required to develop a system that enables the appointed actuary to fully discharge his duties, for example, by providing necessary information.

In addition, the Companies Act requires insurers to ensure the independence of the board of corporate auditors.

The Supervisory Guideline indicates that insurers should conduct appropriate risk management in a systematic and comprehensive manner, and directors should be informed of the status of risk management and make use of the risk information for the execution of business and the improvement of the management system. Senior management is expected to conduct appropriate risk management, such as measuring, monitoring and controlling risks in a manner suited to the types of risks and in line with a risk management policy. Insurers are also expected to conduct stress tests as part of risk management and to have an early warning system.

The Supervisory Guideline indicates that insurers should understand the public nature of the insurance business, comply with laws and regulations, operate their business in a sound and proper manner, and have an effective compliance function. Specifically, for example, the directors are expected to regard compliance as one of the most important management issues and make efforts to ensure compliance. The board of directors is expected to formulate a basic compliance policy and compliance standards, and establish a division responsible for the central management of compliance. When the occurrence of a deplorable event is discovered, a report should be made to the board of directors.

The IBA and the OEIBA require appointed actuaries to evaluate and provide advice on a variety of matters. The appointed actuary is required to report annually to the board of directors, including a written opinion on the following: the appropriateness of technical provisions; the fairness and equitability of the distribution of dividends to policyholders; the continuity of the insurance business based on a rational forecast of future revenues and expenditures; the calculation of insurance premiums; the calculation of technical provisions; the calculation of policy dividends; the calculation of policyholder values; the calculation of accrued insurance premiums; the calculation of provisions for outstanding claims; plans related to insurance solicitation; the formulation of rules on compensation for insurance sales staff; and other items necessary for the performance of its duties.

The Supervisory Guideline indicates that the internal audit division should do the following: formulate an internal audit plan; conduct efficient and effective audits of all business operations of all divisions based on the internal audit manual; report important matters identified in audits to the board of directors without delay; and 


\begin{tabular}{|c|c|}
\hline & $\begin{array}{l}\text { appropriately manage the status of audited divisions' improvements in response to } \\
\text { problems identified in internal audits. } \\
\text { The IBA and the OEIBA provide that insurers may outsource administration, subject to } \\
\text { authorization by the FSA. The FSA sets out its approval criteria in the Supervisory } \\
\text { Guideline. The FSA requires outsourcing service providers to have governance } \\
\text { systems similar to those of insurers. It requires insurers that outsource administration } \\
\text { to establish an internal control system, including appointing a manager in charge of } \\
\text { outsourced operations and developing monitoring and verification systems, and to } \\
\text { conduct internal audits of outsourced operations. The IBA gives the FSA the powers to } \\
\text { require entities to which insurers outsource business operations to submit a report and } \\
\text { to conduct onsite inspections of them as needed. } \\
\text { Through both off-site monitoring-including interviews of directors, executive officers, } \\
\text { risk managers, internal auditors, and appointed actuaries-and onsite inspection, the } \\
\text { FSA assesses the adequacy of an insurer's systems of risk management and internal } \\
\text { controls. This includes the independence of control functions, the sufficiency of their } \\
\text { resources, and the effectiveness of their work. If concerns arise, the FSA takes various } \\
\text { actions, such as requiring insurers to improve their practices and to submit reports or } \\
\text { materials concerning their status. }\end{array}$ \\
\hline Assessment & Observed. \\
\hline Comments & $\begin{array}{l}\text { In recent years, the FSA has more strongly emphasized the importance of risk } \\
\text { management and internal controls, and some insurers have sophisticated systems in } \\
\text { place. } \\
\text { Listed companies are required to provide additional assurance on the adequacy of } \\
\text { their internal controls, under "J-SOX." The FSA should consider whether all insurers } \\
\text { should be subject to the internal control requirements currently applicable to listed } \\
\text { companies. }\end{array}$ \\
\hline ICP 9 & $\begin{array}{l}\text { Supervisory Review and Reporting } \\
\text { The supervisor has an integrated, risk-based system of supervision that uses both off- } \\
\text { site monitoring and onsite inspections to examine the business of each insurer, } \\
\text { evaluate its condition, the quality and effectiveness of its Board and Senior } \\
\text { Management and compliance with legislation and requirements. The supervisor } \\
\text { obtains the necessary supervisory information to conduct effective supervision of } \\
\text { insurers and evaluate the insurance market. }\end{array}$ \\
\hline Description & $\begin{array}{l}\text { As noted under ICP 2, the Supervisory Bureau is responsible for off-site analysis and } \\
\text { the Inspection Bureau is responsible for onsite inspections. In the Supervisory Bureau, } \\
\text { there is a lead person responsible for each insurer, who manages the FSA's ongoing } \\
\text { relationship with the insurer. In the Inspection Bureau, staff are assigned to inspection } \\
\text { teams as inspections occur, rather than being assigned to specific insurers on an } \\
\text { ongoing basis. } \\
\text { The FSA assesses the risks of insurers using information obtained from off-site } \\
\text { monitoring and onsite inspection. The Supervision Bureau is responsible for making } \\
\text { the risk assessments, taking into account information provided by the Inspection } \\
\text { Bureau and obtained through off-site monitoring, the results of market analysis and }\end{array}$ \\
\hline
\end{tabular}


horizontal reviews, and other information. The FSA takes the results of its assessments into account when determining its supervisory program for each insurer. Currently, the risk assessments are not made within a structured system of risk rating. The FSA is testing internally a system in which ratings are given for each of the eight risk categories on which the Inspection Manual is based; it does not yet include an overall risk rating for each insurer. In the area of banking supervision, the FSA already has a risk-rating system and communicates the ratings arising from onsite inspections to the respective banks.

The Supervision Bureau performs ongoing monitoring, including analyzing financial and statistical information and other reports submitted by insurers and conducting regular interviews with them. The results of this monitoring help to determine the timing and scope of onsite inspections. In particular, the Supervision and Inspection Bureaus share information with one another when an inspection is scheduled. A special preinspection analysis group is formed within the Inspection Bureau to establish the scope of the inspection and identify additional information to be sought from the insurer in advance of the inspection.

The IBA, secondary legislation, and the Supervisory Guideline set out the requirements and procedures for supervisory reporting, which include financial and statistical information, and actuarial and solvency position reports. Comprehensive financial information is reported semi-annually, with less detailed quarterly reporting. Some information, such as large exposures, is also reported monthly, and the FSA can request additional information as needed. Financial and statistical information is submitted electronically and can be readily accessed for analysis and comparative reporting.

The IBA and the OEIBA require insurers to report on both solo and consolidated bases. Annual reports must be submitted within four months (3 months for foreign branches) and semi-annual reports within three months; preliminary estimates of key financial information are usually available within 45 days.

The IBA, the Companies Act, the Rules for Terms, Forms, and Methods of Preparing Financial Statements, and the Rules for Terms, Forms, and Methods of Preparing Consolidated Financial Statements prescribe the basis for accounting and consolidation. Insurers are required to report on the basis of Japanese generallyaccepted accounting principles (GAAP).

Financial reports include information on reinsurance and off-balance sheet exposures such as derivatives. The IBA empowers the FSA to require additional information from any member of an insurance group, as well as anyone to which an insurer has outsourced administration. The IBA and the OEIBA require insurers to report promptly any changes that could affect their condition.

The IBA and the Companies Act establish management's responsibility for the accuracy and timeliness of financial statements, business reports, and annexed detailed statements. Annual and semi-annual financial reports are audited; this is requested of foreign branches by the FSA and is legally required of others under the IBA. The IBA also requires audited information to be approved by the board of directors. 
The IBA requires the appointed actuary of an insurer to review various matters annually and submit a report on the results of the review to the board of directors (see ICP 8 for information on the scope of the report), and to submit a copy of the report to the FSA.

The IBA empowers the FSA to require an insurer to correct and resubmit a report that is found to be inaccurate. The IBA provides that an insurer can be punished for false statements and empowers the FSA to take administrative measures, such as issuing business improvement orders or business suspension orders, when deemed necessary.

As indicated in the Supervisory Guideline, the FSA reviews the reporting requirements annually and revises them as appropriate.

The IBA empowers the FSA to require the submission of reports and materials, and to conduct onsite inspections. It does not require the FSA to give advance notice of an inspection, although the FSA rarely conducts an onsite inspection without doing so. The FSA announces scheduled inspections in advance through its website, which provides the public with an explicit opportunity to raise any concerns that might be investigated during the inspection.

The FSA verifies information in financial and statistical reports as part of its onsite inspections. Verification includes the assessment of systems and controls, as well as the testing of transactions and calculations on a sampling basis. The inspectors regularly discuss matters with internal auditors. They review the results of external audits and sometimes meet with the external auditors, ensuring that the auditor's requirement to maintain confidentiality has been waived before doing so. The FSA publishes some of its findings, on an anonymized basis, to educate the industry on problems that were found.

The FSA develops a basic policy and plan for inspections at the beginning of every business year. The purpose and scope of each onsite inspection is determined a month or two in advance of the inspection, taking the insurer's risk profile and other matters into consideration. Generally, large insurers are inspected at least once every three to four years, with smaller insurers being inspected less frequently.

The basic policy describes two types of inspections: "general inspection," under which governance, compliance, risk management systems and practices and business operation of an insurer are assessed comprehensively; and "partial inspection," under which specific areas and issues are focused on and assessed. The IBA does not restrict the FSA's ability to determine the type of inspection it will conduct. The FSA has also developed and published an Inspection Manual.

The general inspection of a large insurer might involve a team of 10 inspectors and extend over a period of seven weeks. Approximately 50 people are regularly involved in performing inspections of insurers, as well as some subject matter specialists.

At the end of an onsite inspection, the inspection team discusses its findings with the insurer and issues a notice of inspection results to the insurer. The FSA requires the insurer to submit, within one month (or less, as necessary), a report that acknowledges the facts pointed out in the notice, analyzes the causes of the facts, and sets out an improvement plan.

The IBA empowers the FSA to conduct an onsite inspection of anyone to which an insurer has outsourced administration. In practice, it has conducted such inspections. 


\begin{tabular}{|c|c|}
\hline Assessment & Largely observed. \\
\hline Comments & $\begin{array}{l}\text { The FSA has been improving the tools used for supervisory assessment. As } \\
\text { mentioned under ICP } 2 \text {, the FSA should build on this by completing the development } \\
\text { of a methodology for risk-rating insurers and adopting a structured system for the } \\
\text { internal review of risk assessments. } \\
\text { Legislation does not require foreign branches to have the financial information that } \\
\text { they submit audited. The FSA has made this a condition of licensing, and individually } \\
\text { informs applicants for foreign branch licenses of the requirement. However, this } \\
\text { requirement should be both strong and transparent. The legislation should be } \\
\text { amended to require foreign branches to submit audited financial information. } \\
\text { The external auditors of an insurer can be a valuable source of information for } \\
\text { supervisors. In some jurisdictions, the legal framework includes provisions that enable } \\
\text { supervisors to place greater reliance on the work of external auditors. They include } \\
\text { giving external auditors the right to provide information to the supervisor without being } \\
\text { subject to lawsuit for breaching confidentiality, requiring external auditors to report to } \\
\text { the supervisor significant adverse information that has come to their attention, enabling } \\
\text { the supervisor to review the working papers of the external auditors, and empowering } \\
\text { the supervisor to require the external auditor to increase the scope of their audit or to } \\
\text { perform a special audit at the expense of the company. The arrangements for } \\
\text { communication with the external auditors should be enhanced, for example, by } \\
\text { meeting regularly with the external auditors and revising the legal framework to include } \\
\text { measures that would enable the FSA to place greater reliance on their work. } \\
\text { The FSA's inspections of insurers appear to be comprehensive and industry } \\
\text { representatives have indicated that the findings have been useful to them in improving } \\
\text { their operations. However, the time between inspections is longer than it should be. } \\
\text { The FSA should increase the frequency of its inspections. For example, it might } \\
\text { inspect all large insurers at least once every two years, high-risk insurers at least } \\
\text { annually, and other insurers at least once every three years. }\end{array}$ \\
\hline ICP 10 & $\begin{array}{l}\text { Preventive and Corrective Measures } \\
\text { The supervisor takes preventive and corrective measures that are timely, suitable and } \\
\text { necessary to achieve the objectives of insurance supervision. }\end{array}$ \\
\hline Description & $\begin{array}{l}\text { The IBA provides that a person who conducts insurance business without a license } \\
\text { shall be punished by imprisonment with work for not more than three years or a fine of } \\
\text { not more than } ¥ 3 \text { million, or both. Where the FSA identifies such a case, it is turned } \\
\text { over to the government prosecutor. This has occurred in practice, although not } \\
\text { recently, and the unauthorized activity was stopped. } \\
\text { The IBA empowers the FSA to take various administrative actions in order to protect } \\
\text { policyholders and to ensure the sound and appropriate management of insurers, } \\
\text { including: } \\
\text { - Requiring an insurer to submit reports or materials concerning the status of its } \\
\text { business or property; } \\
\text { - Having staff enter a facility of an insurer and ask questions on the status of its } \\
\text { business or property, or inspecting relevant objects; }\end{array}$ \\
\hline
\end{tabular}


- Ordering an insurer to modify its statement of business procedures;

- Requesting an insurer to submit a business improvement program;

- Ordering the full or partial suspension of an insurer's business;

- Ordering the dismissal of directors, executive officers, or corporate auditors of insurers; and

- Where a material breach of relevant laws and regulations is identified, recommending to the Minister for Financial Services that the insurer's license be cancelled.

The IBA, the Order Providing for Classification, etc., prescribed in Article 132 (2) of the IBA, and the Supervisory Guideline empower the FSA to intervene on the basis of an insurer's solvency margin ratio (see ICP 17). Intervention is triggered if the solvency margin ratio is less than 200 percent, as follows:

- If the solvency margin ratio is less than 200 percent but more than 100 percent, the FSA can issue an order requiring the submission of an improvement plan deemed reasonable for ensuring managerial soundness, and the implementation of that plan;

- If the solvency margin ratio is less than 100 percent but more than 0 percent, the FSA can issue an order concerning measures that are conducive to improvement of the ability to pay insurance claims; there is a long list of such measures available to the FSA; and

- If the solvency margin ratio is less than 0 percent, the FSA can issue an order for the total or partial suspension of business for a specific period, which can be extended.

The Supervisory Guideline indicates that even in a case where an insurer's solvency margin ratio is more than 200 percent, the FSA may request the insurer to take necessary actions in order to ensure or improve its soundness. This could occur if the insurer has adverse ratios under the early warning system described in the Supervisory Guideline. That system considers the following factors: basic profitability measures and their projections; large credit exposures to the same person; fluctuations of market values of investments; and liquidity conditions.

In practice, the FSA relies largely on requests to insurers to make business improvements as its key preventive and corrective tool. In more serious cases, it has also imposed suspensions of business. Formal administrative actions are publicized by the FSA, which acts as a significant deterrent, but the most recent action was taken in 2009. All insurers have solvency margins well above 200 percent, which is expected to be the case even with the recent strengthening of the risk weights. The solvency margin ratio has not in practice served as a trigger for preventive or corrective measures.

The FSA requires business improvement plans to include acceptable timeframes for making the improvements, and requires the insurer to report the status of implementation periodically.

The FSA communicates with the board, senior management, and key persons in control functions and brings to their attention any material concern in a timely manner to ensure that preventive and corrective measures are taken and the outstanding 


\begin{tabular}{|c|c|}
\hline & $\begin{array}{l}\text { issues are followed through to a satisfactory resolution. Such communication is done } \\
\text { both as needed and through regular interviews of the insurer conducted by the FSA. } \\
\text { The FSA assesses the effectiveness of an insurer's compliance through both off-site } \\
\text { monitoring and onsite inspection, and takes action to deal with noncompliance. As } \\
\text { mentioned above, its publication of administrative actions serves as a deterrent to } \\
\text { noncompliance. }\end{array}$ \\
\hline Assessment & Largely observed. \\
\hline Comments & $\begin{array}{l}\text { The FSA requires insurers to take steps to deal with identified weaknesses, but its } \\
\text { intervention efforts could be enhanced. The adoption of a risk-rating system } \\
\text { (see ICP 2) and the revision of solvency margin control levels (see ICP 17) would } \\
\text { support the FSA's ability to take early preventive and corrective measures. } \\
\text { The FSA prefers to deal with minor regulatory violations through dialogue and moral } \\
\text { suasion, which it has found effective in securing corrective actions. Minor sanctions are } \\
\text { not being applied. At the same time, the formal supervisory administrative action } \\
\text { threshold appears to be high, based on the limited number of such actions taken in the } \\
\text { last } 10 \text { years. } \\
\text { The FSA should make greater use of the tools available to it, such as the power to } \\
\text { impose fines on insurers and intermediaries, to develop a more progressive approach } \\
\text { to enforcement. }\end{array}$ \\
\hline ICP 11 & $\begin{array}{l}\text { Enforcement } \\
\text { The supervisor enforces corrective action and, where needed, imposes sanctions } \\
\text { based on clear and objective criteria that are publicly disclosed. }\end{array}$ \\
\hline Description & $\begin{array}{l}\text { The IBA empowers the FSA to take various administrative actions in order to protect } \\
\text { policyholders and to ensure the sound and appropriate management of insurers (see } \\
\text { ICP 10), including requesting an insurer to submit a business improvement program. } \\
\text { Before the business improvement program is submitted to the FSA, the insurer and the } \\
\text { FSA would generally discuss its content until both find it satisfactory. If this is not } \\
\text { possible or if the implementation of the improvement program is not satisfactory, the } \\
\text { FSA can take additional measures, including the issuance of formal directions. } \\
\text { The FSA has a range of actions available in order to apply appropriate enforcement } \\
\text { where problems are encountered. The IBA provides powers (see ICP 10), which } \\
\text { include the ability to impose restrictions on business activities and to require measures } \\
\text { to reinforce the financial position of an insurer. } \\
\text { The IBA empowers the FSA, when it requires a business improvement plan, to also } \\
\text { require the insurer to report the status of implementation periodically. The FSA } \\
\text { generally requires such reports every six months for the less serious problems and } \\
\text { more frequently for the more serious problems. It assesses the effectiveness of the } \\
\text { improvements, as well as any other action it has taken or has required the insurer to } \\
\text { take. } \\
\text { The IBA empowers the FSA to order the dismissal of directors, executive officers, } \\
\text { corporate auditors, the appointed actuary, and the external auditor of insurers. The } \\
\text { power is explicit with respect to some of these positions, while in other cases it can be }\end{array}$ \\
\hline
\end{tabular}




\begin{tabular}{|c|c|}
\hline & 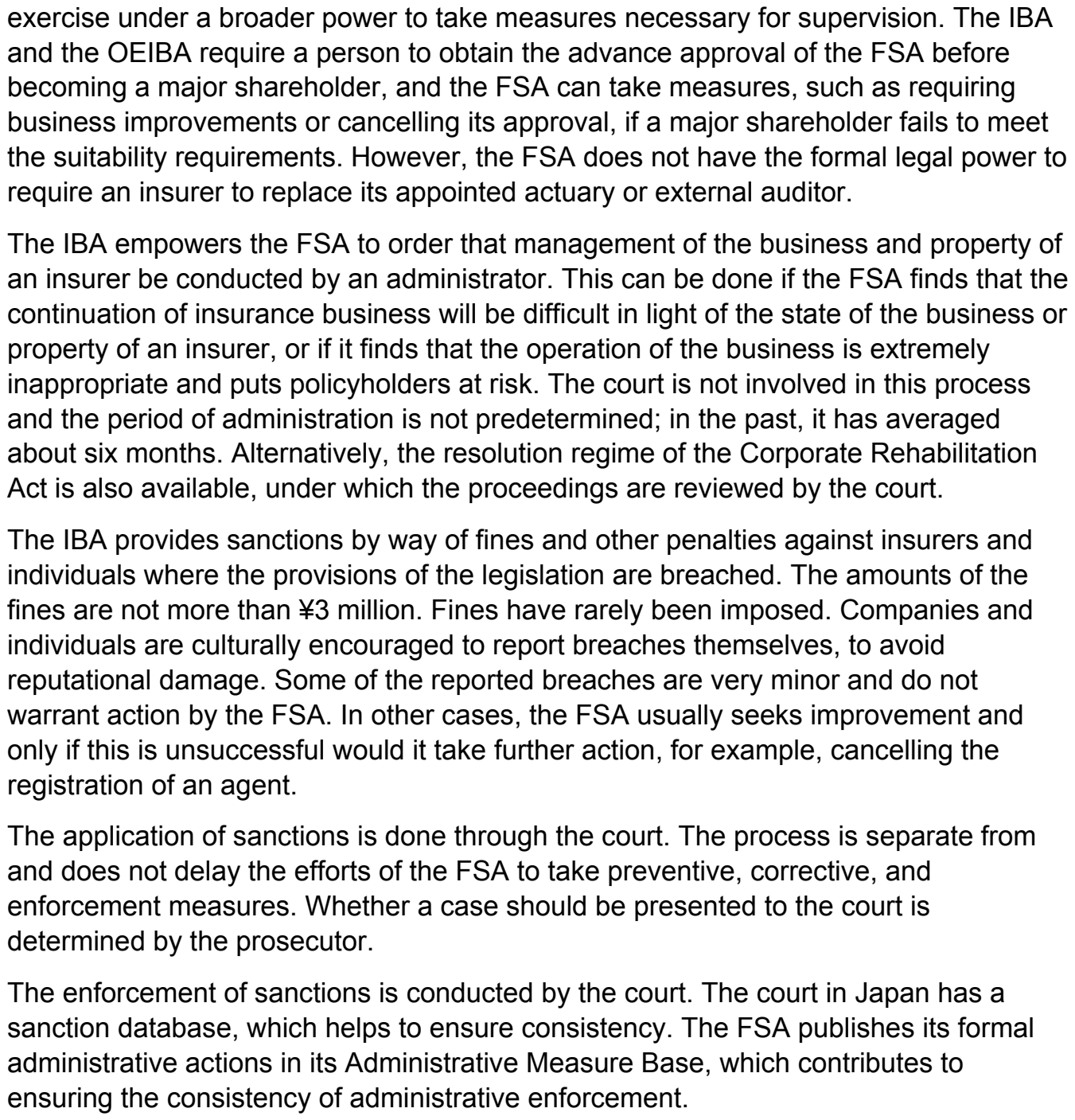 \\
\hline Assessment & Observed. \\
\hline Comments & $\begin{array}{l}\text { In many jurisdictions, the supervisory authority has the power to impose monetary } \\
\text { penalties through administrative means for clearly-defined and less significant } \\
\text { breaches of legislation, such as the late or erroneous submission of required } \\
\text { information. This power supplements its ability to seek court action to deal with major } \\
\text { breaches. The FSA might consider the applicability of such a tool in Japan and, if } \\
\text { appropriate, the legislation should be revised accordingly. }\end{array}$ \\
\hline ICP 12 & $\begin{array}{l}\text { Winding-up and Exit from the Market } \\
\text { The legislation defines a range of options for the exit of insurance legal entities from } \\
\text { the market. It defines insolvency and establishes the criteria and procedure for dealing } \\
\text { with insolvency of insurance legal entities. In the event of winding-up proceedings of } \\
\text { insurance legal entities, the legal framework gives priority to the protection of } \\
\text { policyholders and aims at minimizing disruption to provision of benefits to } \\
\text { policyholders. }\end{array}$ \\
\hline
\end{tabular}




\begin{tabular}{|c|c|}
\hline Description & 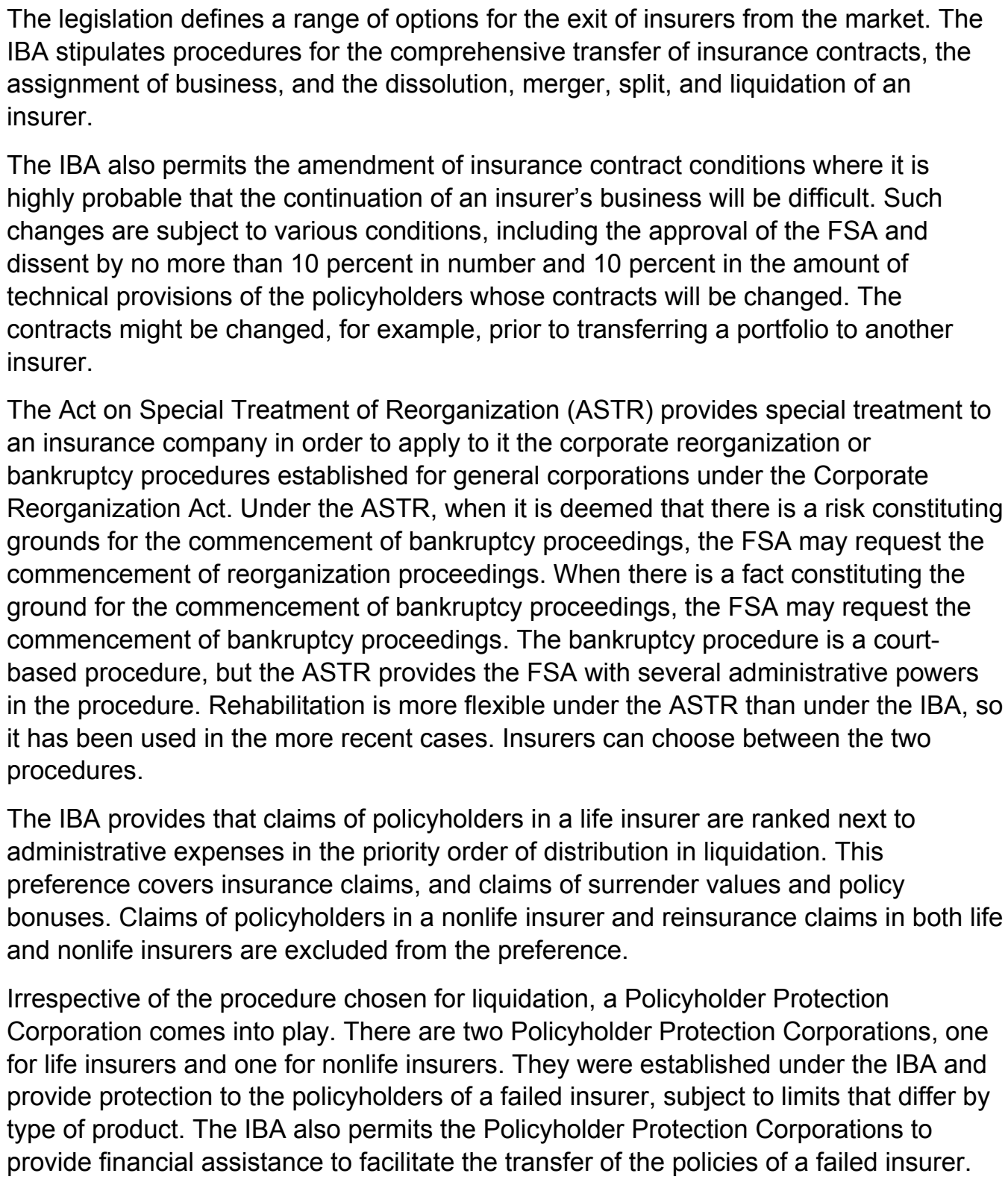 \\
\hline Assessment & Observed. \\
\hline Comments & $\begin{array}{l}\text { The possibility of amending insurance contract conditions where it is highly probable } \\
\text { that the continuation of an insurer's business will be difficult is a useful tool in dealing } \\
\text { with a failed insurer. Such amendments are subject to various conditions, which are } \\
\text { designed to protect consumers. } \\
\text { The FSA should consider seeking an amendment to the IBA to further protect the } \\
\text { rights and entitlements of nonlife insurance policyholders, by extending to them the } \\
\text { same preference on winding-up currently provided to life insurance policyholders. }\end{array}$ \\
\hline
\end{tabular}




\begin{tabular}{|c|c|}
\hline ICP 13 & $\begin{array}{l}\text { Reinsurance and Other Forms of Risk Transfer } \\
\text { The supervisor sets standards for the use of reinsurance and other forms of risk } \\
\text { transfer, ensuring that insurers adequately control and transparently report their risk } \\
\text { transfer programmes. The supervisor takes into account the nature of reinsurance } \\
\text { business when supervising reinsurers based in its jurisdiction. }\end{array}$ \\
\hline Description & 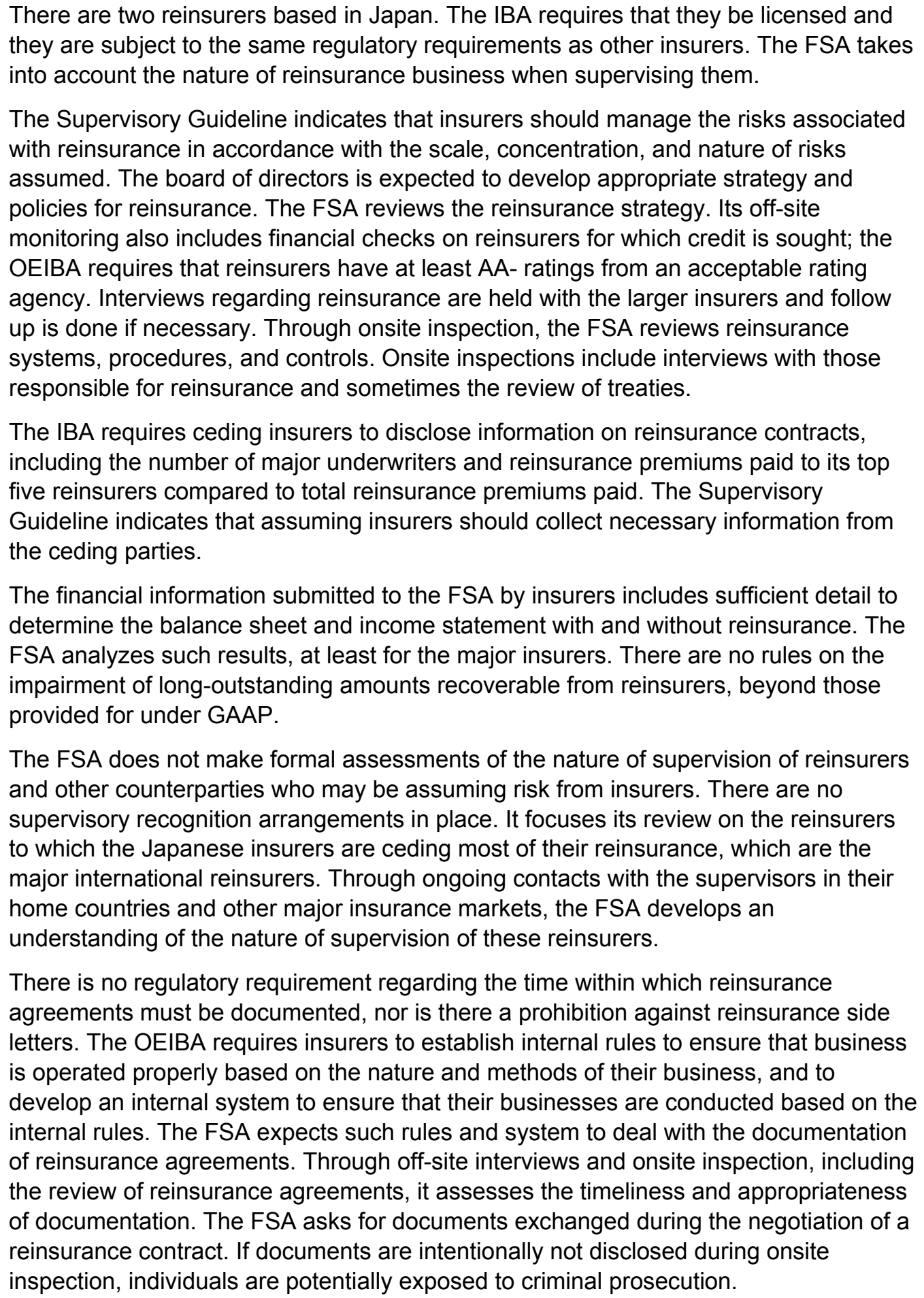 \\
\hline
\end{tabular}




\begin{tabular}{|c|c|}
\hline & $\begin{array}{l}\text { The Supervisory Guideline indicates that insurers should consider the timing of } \\
\text { reinsurance payments in their liquidity management. Through onsite inspection, the } \\
\text { FSA checks whether reinsurers are paying claims in accordance with the contract, } \\
\text { including in terms of timing. Also, when discussing stress testing results with insurers, } \\
\text { particularly tests related to catastrophes, the FSA seeks information on the effects on } \\
\text { liquidity. However, reinsurance agreements are not required to include cash call } \\
\text { provisions. } \\
\text { Insurers are allowed to transfer risk to the capital markets and some have issued } \\
\text { catastrophe bonds. The Supervisory Guideline indicates that insurers are expected to } \\
\text { consult with the FSA if they are seeking to transfer significant risk. In practice, they } \\
\text { have done so and the FSA has assessed the transactions. }\end{array}$ \\
\hline Assessment & Largely observed. \\
\hline Comments & $\begin{array}{l}\text { Japan's exposure to natural catastrophes makes strong reinsurance coverage } \\
\text { essential to the Japanese insurance market and overall economy. The FSA reviews } \\
\text { the reinsurance strategies and programs of insurers, but the regulation and supervision } \\
\text { of reinsurance could be strengthened. The FSA should consider measures such as } \\
\text { stronger documentation requirements (including the prohibition of side letters) and a } \\
\text { more formal assessment of the manner in which foreign reinsurers are supervised. } \\
\text { The exclusion of the cooperatives' insurance programs from the national earthquake } \\
\text { pool might be reconsidered, as it could affect the solvency of those cooperatives in } \\
\text { case of a major event or the failure of reinsurers. }\end{array}$ \\
\hline ICP 14 & $\begin{array}{l}\text { Valuation } \\
\text { The supervisor establishes requirements for the valuation of assets and liabilities for } \\
\text { solvency purposes. }\end{array}$ \\
\hline Description & $\begin{array}{l}\text { The methods used for the valuation of assets and liabilities, except for insurance } \\
\text { liabilities, are specified by GAAP. The methods used for the valuation of insurance } \\
\text { liabilities are specified by the IBA, which is accepted as part of GAAP. These methods } \\
\text { address the recognition, derecognition, and measurement of assets and liabilities. For } \\
\text { example, insurance liabilities are recognized when an insurer bears obligations to } \\
\text { policyholders, and will be derecognized when an insurer is no longer exposed to such } \\
\text { obligations. } \\
\text { Assets and liabilities are valued in a consistent manner under GAAP, for example: } \\
\text { - Long-term insurance liabilities are, in principle, valued based on the interest } \\
\text { rates at the time when an insurance contract was entered into. Assets } \\
\text { corresponding to long-term liabilities are allowed to be measured at amortized } \\
\text { cost; and } \\
\text { - Short-term insurance liabilities are valued based on unearned premiums, } \\
\text { together with claims provisions. Assets corresponding to short-term insurance } \\
\text { liabilities are measured at market value. } \\
\text { Over-the-counter derivatives are valued in various ways, which are reviewed by the } \\
\text { FSA through onsite inspection. The market value of invested real property is required } \\
\text { to be disclosed annually. There is a price fluctuation reserve, which relates to certain }\end{array}$ \\
\hline
\end{tabular}


types of assets, such as equities, bonds, deposits, loans, and gold.

Long-term insurance liabilities are valued based on assumptions, such as interest rates and mortality rates, established at the time when an insurance contract was entered into. The assumptions are set conservatively compared to best-estimates at that time. Future cash flows over the whole period of the insurance contract are estimated and discounted using these assumptions. Accordingly, it is intended that the technical provisions contain implicit risk margins. After the initial measurement, adequacy of the accumulated technical provisions is tested every year. Specifically, cash flows over the next 10 years (at a minimum, although in practice many insurers consider the full time horizon) are estimated using conservative scenarios and then it is judged if the accumulated technical provisions are sufficient to meet future claims payments. Testing is done by product, issue age, and duration cells, although deficiencies for some cells can be offset by surpluses on others. If the testing shows that the technical provisions are insufficient with respect to the first five years of the analysis period, the shortfall is immediately recognized as a liability. Insufficiencies relating to the second five years (or thereafter) are not required to be immediately recognized, but the FSA encourages insurers to be set up additional provisions for the second five years voluntarily. This system requires insurers to hold technical provisions sufficient to fulfill their obligations for at least five years. Under the solvency regulation, it is not allowed to decrease the additional technical provisions established to recognize insufficiencies until the insurance contracts to which they relate are terminated.

For short-term insurance other than fire insurance, there is no explicit requirement to test for the sufficiency of unearned premiums to cover unexpired risk, or to establish an additional provision for unexpired risk should they be insufficient. If unearned premiums are insufficient, the shortfall in the provision would ordinarily be covered by the contingency risk reserve, which is accumulated from previous years' profits.

The valuation of assets and liabilities is largely an economic valuation based on an amortized cost approach. The technical provisions for short-term insurance are not based on discounted cash flows, except those for long-duration claims. Insurers are required to compare the discount rate to the rate observed in the market on every valuation date and, if the relevant conditions stipulated in the IBA are met, the discount rate applicable to new policies must be adjusted.

In addition, the technical provisions for third-sector products (mainly accident and health insurance) are subject to stress testing. Technical provisions for such products are expected to cover risk at no less than the 97.7 percent confidence level, and a contingency reserve should be established to be set to fill any gap between the 97.7 and 99 percent confidence levels.

The valuation of technical provisions and other liabilities does not reflect the insurer's own credit standing.

The valuation of technical provisions is not based on current estimates plus explicit margins over the current estimates. Instead, it is based on assumptions that are intended to be conservative. For example, mortality and morbidity rates are taken from tables prepared by the Institute of Actuaries of Japan, which are calibrated to a confidence level of 97.7 percent.

An equity option valuation approach is used to determine additional provisions and solvency margin for minimum benefits under variable annuities. The FSA is 


\begin{tabular}{|c|c|}
\hline & $\begin{array}{l}\text { considering whether to extend such an approach to the valuation of other types of } \\
\text { options and guarantees, which are currently intended to be covered through the use of } \\
\text { conservative valuation assumptions. }\end{array}$ \\
\hline Assessment & Partly observed. \\
\hline Comments & $\begin{array}{l}\text { Solvency assessment should be based on a transparent economic valuation of assets } \\
\text { and liabilities, which takes into account future cash flows over the full time horizon. The } \\
\text { current methods of valuing insurance liabilities do not meet these criteria (standards } \\
14.8 \text { and } 14.9 \text { ), which creates the risk that liabilities are not being fully recognized. The } \\
\text { combination of basic amortized-cost valuations using conservative assumptions, } \\
\text { additional provisions based on the testing of cash flows, and supplemental reserves is } \\
\text { difficult to understand. Although future cash flows over the full time horizon are taken } \\
\text { into account in the initial valuation of liabilities, this is not necessarily the case in the } \\
\text { subsequent testing of their sufficiency, for which only cash flows during the next } 10 \\
\text { years are required to be considered. The approach to cash flow testing in respect of } \\
\text { the negative spread, as well as the absence of an explicit valuation of some options } \\
\text { and guarantees, create the possibility that liabilities might be understated. } \\
\text { The FSA should revise its valuation approach to take fuller account of emerging } \\
\text { experience and anticipated future experience. } \\
\text { The FSA is currently considering the possibility of moving to a valuation approach that } \\
\text { is more closely related to economic value. In addition, the FSA is considering that } \\
\text { costs regarding options and guarantees will be taken into account when insurance } \\
\text { liabilities are calculated. }\end{array}$ \\
\hline ICP 15 & $\begin{array}{l}\text { Investment } \\
\text { The supervisor establishes requirements for solvency purposes on the investment } \\
\text { activities of insurers in order to address the risks faced by insurers. }\end{array}$ \\
\hline Description & $\begin{array}{l}\text { The IBA, the OEIBA, and the Supervisory Guideline establish requirements applicable } \\
\text { to the investment activities of insurers. The requirements are transparent and their } \\
\text { objectives are communicated by the FSA, for example, through the Supervisory } \\
\text { Guideline. } \\
\text { Requirements address the security, liquidity, and diversification of investments. They } \\
\text { include quantitative limits by type of investment and on the investments with a single } \\
\text { counterparty, as well as restrictions on methods of investment. } \\
\text { The Supervisory Guideline indicates that insurers should maintain sufficient assets } \\
\text { with appropriate characteristics, such as duration and liquidity, to enable them to fulfill } \\
\text { their insurance obligations in the future in light of the nature of the liabilities. } \\
\text { The Supervisory Guideline provides expectations regarding risk management related } \\
\text { to investment, including risk management systems from the standpoint of governance, } \\
\text { market risk management techniques, and risk management systems for credit } \\
\text { investments such as securitization products. Through onsite inspection, the FSA } \\
\text { assesses whether the board of directors, when introducing a new asset management } \\
\text { method that could have a significant impact on soundness of an insurer, considers its } \\
\text { appropriateness in light of the nature of its liabilities, risk tolerance limits and risk } \\
\text { management techniques. As indicated in the Supervisory Guideline, the FSA takes }\end{array}$ \\
\hline
\end{tabular}




\begin{tabular}{|c|c|}
\hline & $\begin{array}{l}\text { action if an insurer invests in assets for which it cannot appropriately assess and } \\
\text { manage the risks. } \\
\text { The IBA allows for the use of derivatives by insurers, both for hedging purposes and } \\
\text { more widely. The Supervisory Guideline indicates that when conducting derivatives } \\
\text { transactions, insurers should conduct appropriate management, such as explicitly } \\
\text { specifying the purpose of and limits on such transactions, the contents of the contracts, } \\
\text { and so forth. } \\
\text { The use of derivatives for purposes other than hedging should be ancillary to the } \\
\text { insurance business. The advance approval of the FSA is required for any ancillary } \\
\text { business activities that an insurer proposes to undertake, so the FSA would expect an } \\
\text { insurer to seek its approval for such uses of derivatives. In the approval process, the } \\
\text { FSA instructs insurers to act conservatively. } \\
\text { More complex and less transparent types of investment are also addressed in the } \\
\text { solvency margin requirement. For example, credit-default swaps re-securitization } \\
\text { products are given risk coefficients different from other asset classes. }\end{array}$ \\
\hline Assessment & Observed. \\
\hline Comments & $\begin{array}{l}\text { The FSA is considering changes to the investment regulations to give insurers more } \\
\text { flexibility in their investment strategies. For example, such changes might include } \\
\text { eliminating the quantitative limit on equity investments, which is increasingly affecting } \\
\text { some nonlife insurers as their long-term, premium-refund business declines. At the } \\
\text { same time, some insurers are actively reducing their exposure to equities in order to } \\
\text { reduce market risk and improve returns (in the case of equities purchased as a way to } \\
\text { attract insurance business from the issuers). } \\
\text { Some jurisdictions supplement quantitative investment limitations with an overriding } \\
\text { requirement that insurers invest in the manner of a prudent person. Such a } \\
\text { requirement can be particularly useful-both in reinforcing the need for good behavior } \\
\text { and empowering supervisory intervention-if quantitative investment limitations are } \\
\text { being relaxed. The FSA might consider whether the inclusion of a prudent person } \\
\text { requirement in the IBA would be similarly useful in Japan. }\end{array}$ \\
\hline ICP 16 & $\begin{array}{l}\text { Enterprise Risk Management for Solvency Purposes } \\
\text { The supervisor establishes enterprise risk management requirements for solvency } \\
\text { purposes that require insurers to address all relevant and material risks. }\end{array}$ \\
\hline Description & $\begin{array}{l}\text { The Supervisory Guideline indicates that insurers should recognize all material risks as } \\
\text { part of enterprise risk management, including insurance underwriting risk, credit risk, } \\
\text { market risk, liquidity risk, operational risk, and information system risk. It also states } \\
\text { that the board of directors should make necessary decisions, considering the } \\
\text { insurance company's capital adequacy based on risks and economic valuation. To do } \\
\text { so, the enterprise risk management framework would need to provide for the } \\
\text { identification and quantification of risk. }\end{array}$ \\
\hline
\end{tabular}


The Supervisory Guideline indicates that insurers should properly determine and document the risks that are subject to quantitative enterprise risk management. The Inspection Manual elaborates on the need to document the measurement approaches and key assumptions.

The Supervisory Guideline indicates that the board of directors should develop a policy for enterprise risk management that is aligned with the strategic goals and the corporate management policy of the insurer. The specific items to be covered in the policy are described in the Inspection Manual.

The risk management policy is not explicitly required to describe the relationship between the insurer's tolerance limits, regulatory capital requirements, economic capital, and the processes and methods for monitoring risk. However, the Supervisory Guideline indicates that the board of directors should take regulatory capital and risk tolerance into account, and that an insurer should calculate economic capital.

The Supervisory Guideline indicates that an insurer should have a comprehensive policy for asset-liability management, along with a system for asset-liability management. Insurers are required to submit information on asset and liability cash flows by duration categories, for the company as a whole.

The Supervisory Guideline indicates that insurers should have a risk management policy that takes into consideration market risk, credit risk, liquidity risk, and other risks. It also states that they should appropriately identify risks involved in assets that have a unique risk profile. The Supervisory Guideline indicates that insurers should have an appropriate risk management system for investment risk. The items to be dealt with in the investment policy are described in the Inspection Manual; they do not include a target asset mix.

The Supervisory Guideline indicates that insurers should have a risk management policy that takes into consideration underwriting risks, while the Inspection Manual describes the items that the policy should cover.

Through onsite inspection, the FSA checks whether the enterprise risk management policy explicitly describes the insurer's policies for setting risk tolerance limits and for identifying risks subject to management, and whether the risk management division monitors compliance with the risk tolerance limits. It also reviews whether an insurer has set strategic goals that specify profit goals and risk-taking strategy for the entire company.

The Supervisory Guideline indicates that insurers should appropriately review and revise the enterprise risk management framework in response to changes in circumstances. The Inspection Manual states that insurers should do an updated risk analysis for major product changes.

The Supervisory Guideline indicates that insurers should make efforts to improve the accuracy of the quantification of risks and expand the range of risks subject to the quantification. The FSA reviews whether an insurer's processes for the development of the policy for enterprise risk management are effective, and whether the policy is reviewed and revised in a timely manner.

As mentioned above, the Supervisory Guideline states that the board of directors should make necessary decisions, considering the insurance company's capital adequacy based on risks and economic valuation. It deals with many elements that would be covered by an own risk and solvency assessment (ORSA). 


\begin{tabular}{|c|c|}
\hline & $\begin{array}{l}\text { The Supervisory Guideline indicates that insurers should make efforts to assess } \\
\text { business continuity, such as analyzing future capital adequacy in light of medium- and } \\
\text { long-term business strategies and the business environment, such as changes in the } \\
\text { value of policies in force and in the product mix. The IBA and the OEIBA require the } \\
\text { appointed actuary to check whether it is difficult for an insurer to continue its insurance } \\
\text { business in light of the results projected rationally, based on its future revenues and } \\
\text { expenditures on the basis of actuarial data. The appointed actuary must submit the } \\
\text { results of the projection to the FSA and explain it, as needed. The Supervisory } \\
\text { Guideline and the Inspection Manual describe expectations regarding stress testing. } \\
\text { The FSA assesses an insurer's enterprise risk management policies, procedures, and } \\
\text { practices through both off-site interviews and onsite inspections. The IBA empowers } \\
\text { the FSA to take action, such as issuing a business improvement order, to require the } \\
\text { strengthening of an insurer's risk management, solvency assessment and capital } \\
\text { management processes. }\end{array}$ \\
\hline Assessment & Largely observed. \\
\hline Comments & $\begin{array}{l}\text { Enterprise risk management is an evolving field, both in Japan and internationally. } \\
\text { Some Japanese insurers have sophisticated enterprise risk management systems, } \\
\text { while others are at earlier stages of development. } \\
\text { The Supervisory Guideline was revised to deal more extensively with risk management } \\
\text { in response to the global financial crisis, while the Inspection Manual was updated in } \\
2011 \text { to include a section explicitly on this topic. Through interviews, the FSA has done } \\
\text { a thematic review of the enterprise risk management processes of selected insurers. } \\
\text { The FSA should enhance its guidance on enterprise risk management to indicate that } \\
\text { insurers should explicitly describe the relationship between their risk tolerance limits, } \\
\text { regulatory capital requirements, economic capital, and the processes and methods for } \\
\text { monitoring risk. It should also provide more explicit guidance regarding the } \\
\text { performance of own risk and solvency assessment. The FSA should encourage } \\
\text { insurers to include the target asset mix as part of their investment policies. It should } \\
\text { also consider incorporating basic requirements to perform enterprise risk management } \\
\text { in the legislation, and communicate more specific expectations through the } \\
\text { Supervisory Guideline. } \\
\text { The FSA should actively supervise the efforts of insurers in this area, to help ensure } \\
\text { that their capabilities are evolving at an appropriate pace. }\end{array}$ \\
\hline ICP 17 & $\begin{array}{l}\text { Capital Adequacy } \\
\text { The supervisor establishes capital adequacy requirements for solvency purposes so } \\
\text { that insurers can absorb significant unforeseen losses and to provide for degrees of } \\
\text { supervisory intervention. }\end{array}$ \\
\hline Description & $\begin{array}{l}\text { The IBA and the OEIBA prescribe solvency margin requirements for insurers and } \\
\text { insurance holding companies. The solvency margin requirements take a total balance } \\
\text { sheet approach. The required solvency margin is calculated using risk weights that are } \\
\text { applied to both assets and liabilities. The available solvency margin is calculated } \\
\text { based on the GAAP balance sheet. } \\
\text { The solvency margin requirements have recently been changed and the new }\end{array}$ \\
\hline
\end{tabular}


requirements must be met effective March 31,2012 . The risk weights for insurance underwriting risk and asset management risk are based on a 95 percent confidence level over one year, compared to about 90 percent under the previous requirements. The solvency margin ratios of insurers will decrease significantly as a result of this strengthening of the requirements. In addition, the IBA requires insurers to have capital of at least $¥ 1$ billion.

The solvency margin requirements include solvency control levels that trigger progressively more severe supervisory actions (see ICP 10). In practice, they have not triggered supervisory action because all insurers have maintained solvency margin ratios significantly above the control levels. There are three solvency control levels: 200 percent, above which the FSA would ordinarily not intervene; 100 percent; and 0 percent, which triggers the strongest actions.

The solvency margin requirements, including the solvency control levels, apply at the group level effective March 31, 2012.

The solvency margin requirements are established in an open and transparent process. Development of the recent changes began in November 2006, when a working group of the FSA and outside experts was established. In February 2008, an outline was issued for public comment. It was modified in response to the global financial crisis, an impact assessment was conducted by the FSA with the cooperation of industry, and a concrete proposal was issued for public comment in December 2009. The final version was issued in April 2010.

The required solvency margin is primarily calculated using a standardized approach. However, the use of internal models is allowed for the calibration or calculation of the technical provisions and the required solvency margin for catastrophe and minimum guarantee risks.

A notice under the OEIBA specifies the risks to be addressed and the method of aggregating risks, including the correlation among risks. Most risk categories are addressed. Many risks are addressed in both the technical provisions and the solvency margin requirements, at different confidence levels.

A notice under the OEIBA specifies the confidence levels for risk calibration of the required solvency margin, as follows: earthquake risk, 99.5 percent; storm and flood damage risk, 98.6 percent; mortality risk, 99.0 percent; and asset management risk, 95.0 percent. In each case, the time horizon is one year.

The FSA does not impose variations to the solvency margin requirements on individual insurers.

The IBA, the OEIBA and Notice 50 thereunder, as well as the Supervisory Guideline, define the available solvency margin and describe the methods for its calculation. The IBA prescribes a limitation on the amount which can be regarded as capital and defines the core margin.

The IBA prescribes various adjustments to the GAAP balance sheet capital to take account of its loss absorbency. Examples include: there is a limit on the amount of deferred tax assets which can be counted as margin; redeemable debt capital instruments have to meet specific criteria; goodwill cannot be counted; the portion of the cancellation technical provision that exceeds the surrender value can be counted; and catastrophe reserves can be counted. A core margin, which has higher quality and loss absorbency, is also defined. 


\begin{tabular}{|c|c|}
\hline & $\begin{array}{l}\text { As noted above, the use of internal models is allowed for the calculation of the required } \\
\text { solvency margin for catastrophe and minimum guarantee risks. Prior supervisory } \\
\text { approval is required. In practice, very few insurers are using internal models; in those } \\
\text { cases, approval was granted several years ago. } \\
\text { There is neither a statistical quality test nor a calibration test. } \\
\text { Notice } 50 \text { under the OEIBA specifies criteria for the approval of the use of an internal } \\
\text { model with regard to minimum guarantee risk, which include the involvement of senior } \\
\text { management and governance over the model. There is no explicit provision requiring } \\
\text { governance over a catastrophe model, but in practice the FSA would require } \\
\text { appropriate governance before approving the use of the model. } \\
\text { Notice } 23 \text { under the OEIBA specifies additional criteria for the approval of the use of an } \\
\text { internal model with regard to minimum guarantee risk, which include having the policy, } \\
\text { management, and procedures for the operation of the risk measurement model, } \\
\text { governance over the model, and the documentation of elements used for risk } \\
\text { measurement. In addition, calibration methods, assumptions and results of calibration } \\
\text { must be disclosed. There are no such explicit provisions regarding a catastrophe } \\
\text { model, but in practice the FSA would require appropriate documentation before } \\
\text { approving the use of the model. } \\
\text { Notice } 23 \text { under the OEIBA requires an insurer to notify the FSA of a material change } \\
\text { to an approved internal model. The FSA would review the information and decide } \\
\text { whether to maintain its continued approval. }\end{array}$ \\
\hline Assessment & Largely observed. \\
\hline Comments & $\begin{array}{l}\text { The required solvency margin should include risk margins for any mismatching of } \\
\text { assets and liabilities, not just a risk margin for interest-rate risk. The required solvency } \\
\text { margin should also be enhanced to consider the ratings of reinsurers in the risk } \\
\text { weights applied to reinsurance credit exposures. } \\
\text { It is important that solvency requirements be sufficiently strong, while not being } \\
\text { onerous. There are various steps that can be taken to achieve this balance, such as } \\
\text { requiring insurers to model risks internally and reviewing the results, and comparing } \\
\text { the requirements with those of other jurisdictions with similarly sophisticated insurance } \\
\text { markets. For the most recent revisions, the risk parameters were calculated by the } \\
\text { FSA, based on historical experience. In the future, the FSA should consider enhancing } \\
\text { the process by asking insurers to model risk scenarios and making detailed } \\
\text { comparisons to the solvency regimes of other jurisdictions. } \\
\text { It has been at least } 10 \text { years since any insurer has fallen below the } 200 \text { percent } \\
\text { solvency control level-including an insurer that failed. Even with the recent } \\
\text { strengthening of the risk weights, most insurers are likely to remain well above the } \\
\text { control levels. In order to serve as an effective supervisory tool, the highest solvency } \\
\text { control level should be closer to the level that insurers typically maintain in order to be } \\
\text { considered strong internally and by market participants. The FSA should consider } \\
\text { increasing the solvency control levels. } \\
\text { The FSA does not impose variations to the solvency margin requirements on individual } \\
\text { insurers. The supervisors in some jurisdictions do so, for example, to take account of } \\
\text { risk characteristics of an insurer that are not fully captured by the standardized } \\
\text { formulas. The FSA should consider imposing variations to the solvency margin }\end{array}$ \\
\hline
\end{tabular}




\begin{tabular}{|c|c|}
\hline & $\begin{array}{l}\text { requirements in cases where the risk characteristics of individual insurers are not fully } \\
\text { captured by the standardized formulas. } \\
\text { Very few insurers are using internal models for solvency margin calculations. However, } \\
\text { the requests to do so are likely to increase in the future, as insurers build their } \\
\text { enterprise risk management capabilities and gain comfort in using the related models. } \\
\text { The FSA should update its model approval standards to conform to current best } \\
\text { practices. }\end{array}$ \\
\hline ICP 18 & $\begin{array}{l}\text { Intermediaries } \\
\text { The supervisor sets and enforces requirements for the conduct of insurance } \\
\text { intermediaries, to ensure that they conduct business in a professional and transparent } \\
\text { manner. }\end{array}$ \\
\hline Description & 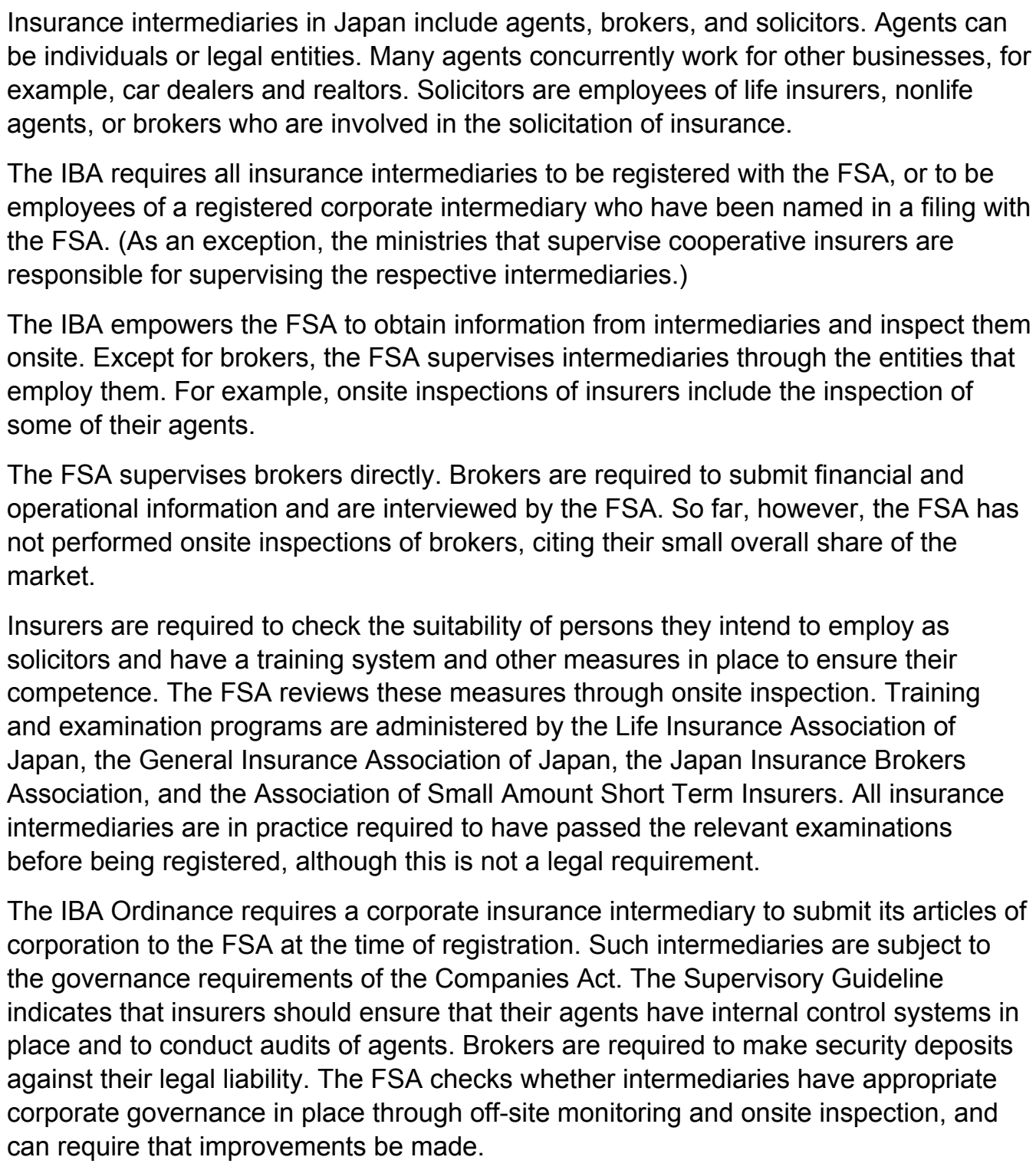 \\
\hline
\end{tabular}




\begin{tabular}{|c|c|}
\hline & $\begin{array}{l}\text { The IBA and the IBA Ordinance require insurance intermediaries to disclose material } \\
\text { information to customers. For example, solicitors must disclose the name of the insurer } \\
\text { for which they are acting and whether their role is to conclude a contract on behalf of } \\
\text { the insurer or mediate between the insurer and the customer. Brokers must disclose } \\
\text { their responsibilities, liability for damage, and, if requested by the customer, the basis } \\
\text { on which they are remunerated. } \\
\text { The Supervisory Guideline states that insurance intermediaries who handle client } \\
\text { monies should have sufficient safeguards in place. For example, nonlife agents should } \\
\text { manage premiums received separately from their own property. Brokers are not } \\
\text { permitted to handle client monies. The FSA checks the handling of client monies } \\
\text { through onsite inspection. } \\
\text { The IBA provides that any person who engages in insurance solicitation without } \\
\text { registering with the FSA is subject to imprisonment for up to one year, a fine of up to } \\
¥ 1 \text { million, or both. } \\
\text { The FSA can order intermediaries to take measures to improve their business to the } \\
\text { extent necessary to protect policyholders. The FSA can suspend the registration of an } \\
\text { insurance intermediary for up to six months or cancel its registration for various } \\
\text { reasons specified in the IBA. }\end{array}$ \\
\hline Assessment & Largely observed. \\
\hline Comments & $\begin{array}{l}\text { Onsite inspection is an important tool in the supervision of both insurers and insurance } \\
\text { intermediaries. The FSA should perform periodic onsite inspections of brokers, even } \\
\text { though they account for a small share of the market in Japan. } \\
\text { Consideration should also be given to making it a legal requirement that all insurance } \\
\text { intermediaries pass examinations as a condition of registration. }\end{array}$ \\
\hline ICP 19 & $\begin{array}{l}\text { Conduct of Business } \\
\text { The supervisor sets requirements for the conduct of the business of insurance to } \\
\text { ensure customers are treated fairly, both before a contract is entered into and through } \\
\text { to the point at which all obligations under a contract have been satisfied. }\end{array}$ \\
\hline Description & $\begin{array}{l}\text { The IBA requires that insurers take necessary measures to ensure that material } \\
\text { matters on their business are explained to customers, customer information received in } \\
\text { relation to their business operation is treated in an appropriate manner, business } \\
\text { entrusted to third parties is carried out properly, and their business operations are } \\
\text { sound and proper. Specific requirements and guidance on the conduct of business are } \\
\text { also set out in the IBA Ordinance, the Supervisory Guideline, and the Inspection } \\
\text { Manual. The FSA supervises the conduct of insurers and intermediaries with respect to } \\
\text { these requirements through off-site monitoring and onsite inspections, which generally } \\
\text { cover consumer protection matters. } \\
\text { The IBA Ordinance requires insurers to take measures to ensure that intermediaries } \\
\text { provide material information on insurance products to customers. Through onsite } \\
\text { inspection, the FSA assesses an insurer's internal systems for the protection of } \\
\text { policyholders, such as the communication of internal rules to relevant departments, } \\
\text { staff members, and intermediaries and the verification of compliance. }\end{array}$ \\
\hline
\end{tabular}


The IBA requires insurers to obtain the approval of the FSA before introducing new products. The Supervisory Guideline indicates that the FSA expects insurers to develop new products with ingenuity, taking into account customer needs and changes in needs. An insurer must submit information about the target market for a new product. The FSA assesses new products from the perspectives of both financial soundness and consumer protection. Through onsite inspection, the FSA reviews whether a system is in place to ensure that new products are both appropriate and meet legal requirements.

The IBA and the IBA Ordinance prescribe various requirements regarding the promotion of products and services. For example, the IBA prohibits the delivery of false information to customers, the replacement of policies without disclosing possible disadvantages, and the provision of information that may confuse customers. It also requires brokers to conduct their business with integrity. The Supervisory Guideline elaborates on these requirements. Through onsite inspection, the FSA reviews whether systems are in place to ensure that intermediaries explain the contents and risks of products, in consideration of customers' needs, knowledge and experience.

The IBA requires intermediaries to provide material information regarding the product to customers, while the Supervisory Guideline details the information that needs to be provided. Through onsite inspection, the FSA reviews whether systems are in place to ensure that the relevant documents are provided at the appropriate time.

The IBA Ordinance requires insurers to establish policies and procedures to ensure that customers are informed of material matters according to their knowledge, experience, financial status, and the purpose of the transaction. The Supervisory Guideline expands on this, for example, indicating that insurers and intermediaries must confirm in writing that a product matches the customer's needs; the confirmation document must be provided to the customer and a copy retained in the files. Through onsite inspection, the FSA reviews whether relevant systems are in place.

The IBA includes various requirements to manage conflicts of interest, which are in some cases expanded upon in the Supervisory Guideline. For example, life insurers are restricted in using the intermediaries of other insurers to distribute their products, brokers are required to work in the customers' best interests and disclose their remuneration upon request, and insurers and intermediaries are prohibited from providing customers with extraordinary benefits such as discounts on insurance premiums. Through onsite inspection, the FSA reviews whether systems for managing conflicts of interest are in place, along with measures for ensuring the effectiveness.

Insurers are required to service policies appropriately. For example, the IBA Ordinance requires the periodic disclosure of information on the performance of asset management for variable life and annuity products. Through onsite inspection, the FSA reviews the manner in which information is provided to customers during the life of the contract.

The Supervisory Guideline indicates that insurers should have policies and procedures in place to handle claims payment in a timely and fair manner. They are also expected to comply with guidelines for claims payment established by the Life Insurance Association of Japan and the General Insurance Association of Japan. Through onsite inspection, the FSA reviews the measures taken by insurers to ensure the timely and appropriate payment of claims, as well as claims-payment aging information. Several years ago, the FSA identified widespread problems involving the inappropriate payment of claims and took action to require insurers to strengthen their claims- 


\begin{tabular}{|c|c|}
\hline & $\begin{array}{l}\text { payment processes. } \\
\text { The Supervisory Guideline indicates that insurers should have internal systems for } \\
\text { handling complaints. Through onsite inspection, the FSA reviews the adequacy of such } \\
\text { systems. Other mechanisms are also available to consumers who have complaints. } \\
\text { The FSA has a complaints hotline, and the unit responsible for it cooperates with the } \\
\text { government's Consumer Agency. The IBA provides that the FSA can approve } \\
\text { organizations that meet criteria for dispute resolution; several such organizations have } \\
\text { been established by industry associations. } \\
\text { The Act on the Protection of Personal Information provides requirements regarding the } \\
\text { protection of personal information. For example, it stipulates that a person handling } \\
\text { personal information shall specify the purpose for which such information will be used } \\
\text { and shall not, except in certain cases stipulated by the Act, provide personal } \\
\text { information to a third party without obtaining prior consent from the relevant individual. } \\
\text { The IBA Ordinance requires insurers to take necessary measures to ensure that } \\
\text { personal information is not used for purposes other than their business activities and } \\
\text { that it is not divulged, lost or impaired by third parties to which the management of } \\
\text { customer information has been outsourced. The Supervisory Guideline also states that } \\
\text { insurers and intermediaries should treat customer information in an appropriate } \\
\text { manner. Through onsite inspection, the FSA reviews whether insurers have developed } \\
\text { adequate rules for the protection of customer information and have communicated } \\
\text { them to the relevant departments and staff members. } \\
\text { The FSA provides various types of information that support the fair treatment of } \\
\text { customers. For example, it issues warning notices regarding unauthorized solicitation, } \\
\text { publishes consumer education leaflets on its website, and sends staff to speak at } \\
\text { meetings and conferences for the purpose of consumer education. }\end{array}$ \\
\hline Assessment & Observed. \\
\hline Comments & $\begin{array}{l}\text { Some supervisors have created units responsible for taking the lead on customer } \\
\text { protection, which helps to ensure that such issues are identified in a timely manner and } \\
\text { dealt with appropriately. The FSA might consider creating a customer protection unit. }\end{array}$ \\
\hline ICP 20 & $\begin{array}{l}\text { Public Disclosure } \\
\text { The supervisor requires insurers to disclose relevant, comprehensive and adequate } \\
\text { information on a timely basis in order to give policyholders and market participants a } \\
\text { clear view of their business activities, performance and financial position. This is } \\
\text { expected to enhance market discipline and understanding of the risks to which an } \\
\text { insurer is exposed and the manner in which those risks are managed. }\end{array}$ \\
\hline Description & $\begin{array}{l}\text { The IBA requires insurers to disclose various information annually and keep it available } \\
\text { to the public. The OEIBA specifies in detail the items to be disclosed, which include } \\
\text { organizational, operational, financial, statistical, and risk management information, } \\
\text { along with information on subsidiaries. Consistency and comparability in the manner of } \\
\text { disclosure are promoted by both the OEIBA and guidance provided by the FSA and } \\
\text { industry associations. The FSA reviews the disclosures and periodically updates its } \\
\text { guidance. } \\
\text { The OEIBA requires insurers to disclose technical provisions by insurance segment, }\end{array}$ \\
\hline
\end{tabular}


together with the actuarial methods and assumptions used in the calculations. The IBA specifies the manner in which key assumptions are to be determined.

Insurers are required to disclose information on capital adequacy. The IBA and OEIBA require disclosure of the solvency margin ratio, including information on available capital resources and the requirements in respect of various risk categories. Currently, internal models can only be used to calculate the requirements for catastrophe risks and minimum guarantee risks. Information on the internal models used for minimum guarantee risk must be publicly disclosed, while those used for catastrophe risks are approved by the FSA but are not required to be publicly disclosed.

The OEIBA and accounting standards require insurers to disclose information about their investments, including detailed quantitative and qualitative information by class. Quantitative information disclosed includes amounts outstanding, acquisition values or contract values, market values, and unrealized profits and losses on securities and derivatives. Qualitative information disclosed includes investment policies, risk management systems, and supplementary explanations, for example, about matters related to market prices of financial instruments. Insurers are not required to disclose information concerning the level of sensitivity to market variables associated with disclosed amounts, although some do so voluntarily.

The OEIBA requires insurers to disclose information about their risk management systems. The information to be disclosed is not specified, but in practice insurers disclose at least the overall structure of their risk management systems and basic policies of risk management. The disclosures do not always include information about the methodology used and the key assumptions employed in measuring assets and liabilities for ALM purposes. There are no requirements to hold capital or provisions as a consequence of a mismatch between assets and liabilities, except for cases where a negative interest-rate spread cannot be covered by expected gains on mortality and expenses.

The OEIBA requires insurers to disclose information on financial performance, both in total and by segment. The information disclosed includes a qualitative analysis of sources of core profit, a table regarding claims development, and returns on investment assets.

The OEIBA requires insurers to disclose qualitative information on risk management, including: the objectives, policies, models and techniques for managing underwriting risk; the nature, scale and complexity of risks arising from insurance contracts; reinsurance and other forms of risk transfer; the interaction between capital adequacy and risk; and sensitivity to changes in the loss ratio. The Supervisory Guideline encourages disclosure regarding stress testing.

The OEIBA requires insurers to provide information on their business, the external environment in which they operate, and their organization. In addition, the Financial Instruments and Exchange Act require listed companies to submit Annual Securities Reports, in which information on corporate governance must be disclosed; such reports are available to the public. The Supervisory Guideline indicates that mutual insurers are expected to disclose the proceedings of meetings of policyholder representatives, for example, on their websites. Although there are no explicit requirements to describe key products and business strategies, insurers typically do so. 


\begin{tabular}{|c|c|}
\hline & $\begin{array}{l}\text { The Companies Act requires Japanese companies to have their financial statements } \\
\text { audited annually. The FSA requires branches of foreign insurers to provide audit } \\
\text { opinions, through a separate order to each insurer. The OEIBA requires insurers to } \\
\text { disclose the fact that they have been audited and to make their audited financial } \\
\text { statements publicly available. }\end{array}$ \\
\hline Assessment & Largely observed. \\
\hline Comments & $\begin{array}{l}\text { Currently, few insurers are using internal models to calculate the solvency } \\
\text { requirements for catastrophe risks. However, those that do so are not required to } \\
\text { disclose information about such models. The disclosure requirements should be } \\
\text { revised to require the public disclosure of information about the internal models used to } \\
\text { calculate the solvency requirements for catastrophe risks. } \\
\text { Insurers disclose a significant amount of information, some of which goes beyond the } \\
\text { legally-required disclosures. However, there are some areas that should be } \\
\text { strengthened. The FSA should enhance the requirements to include the disclosure of } \\
\text { information such as: } \\
\text { - The level of sensitivity of investment values to market variables; } \\
\text { - The methodology used and the key assumptions employed in measuring } \\
\text { assets and liabilities for ALM purposes; } \\
\text { - A quantitative analysis of sources of earnings; } \\
\text { - Quantitative information about material risk exposures, including } \\
\text { - The nature of stress testing being performed. } \\
\text { Insurers disclose their exposures to reinsurers by ratings category. This is useful } \\
\text { information, but it does not enable users to assess the possible effects of reinsurance } \\
\text { concentrations. The FSA should consider requiring the disclosure of reinsurance } \\
\text { premium concentration ratios. }\end{array}$ \\
\hline ICP 21 & $\begin{array}{l}\text { Countering Fraud in Insurance } \\
\text { The supervisor requires that insurers and intermediaries take effective measures to } \\
\text { deter, prevent, detect, report, and remedy fraud in insurance. }\end{array}$ \\
\hline Description & $\begin{array}{l}\text { Fraud in insurance is addressed in the Criminal Code. } \\
\text { The FSA has developed its understanding of fraud risks through mechanisms such as } \\
\text { off-site monitoring, onsite inspection, and interviews of insurers. } \\
\text { Insurers and intermediaries are required to have controls in place to deter, prevent, } \\
\text { detect, report and remedy fraud in insurance. Insurers are required by the IBA to notify } \\
\text { the FSA of cases of fraud that they identify, either within their own operations or those } \\
\text { of subsidiaries. The FSA assesses the effectiveness of these controls through off-site } \\
\text { monitoring and onsite inspection, including substantive testing of claims files. The FSA } \\
\text { requires that improvements be made to remedy any deficiencies. The effectiveness of } \\
\text { the supervisory methodology is reviewed from time to time, and enhancements are } \\
\text { currently being considered. }\end{array}$ \\
\hline
\end{tabular}




\begin{tabular}{|c|c|}
\hline & $\begin{array}{l}\text { Insurers are encouraged to report to the police any cases of fraud that they identify. } \\
\text { The FSA is able to cooperate, coordinate, and exchange information regarding fraud in } \\
\text { insurance with both law enforcement authorities and, subject to confidentially } \\
\text { requirements, other supervisors. }\end{array}$ \\
\hline Assessment & Observed. \\
\hline Comments & $\begin{array}{l}\text { Fraud in insurance has not been a significant problem in Japan. Relatively few cases } \\
\text { of fraud have been reported, but there are no statistics on the extent of fraud or its cost } \\
\text { to insurers-and ultimately, to consumers. This situation might change, for example, } \\
\text { as insurers develop new products that provide different types of living benefits than } \\
\text { traditional products. In some jurisdictions, insurers cooperate in a formal manner to } \\
\text { share information that supports the detection of fraud. The FSA should encourage the } \\
\text { industry associations to maintain industry-wide data bases to help detect fraud. }\end{array}$ \\
\hline ICP 22 & $\begin{array}{l}\text { Anti-Money Laundering and Combating the Financing of Terrorism } \\
\text { The supervisor requires insurers and intermediaries to take effective measures to } \\
\text { combat money laundering and the financing of terrorism. In addition, the supervisor } \\
\text { takes effective measures to combat money laundering and the financing of terrorism. }\end{array}$ \\
\hline Description & $\begin{array}{l}\text { The FSA is a member of the Financial Action Task Force, which contributes to its } \\
\text { understanding of ML/FT risks in insurance. It also builds its understanding through } \\
\text { interviews with and onsite inspections of insurers and analysis of suspicious } \\
\text { transactions reports. A unit within the Supervisory Bureau receives and analyzes } \\
\text { suspicious transactions reports, while others within that bureau review AML/CFT } \\
\text { procedures and interview insurers. The Inspection Bureau deals with AML/CFT issues } \\
\text { in connection with its review of compliance, which is normally a part of onsite } \\
\text { inspections. These activities strengthen the organization's understanding of ML/FT } \\
\text { risks, and training on AML/CFT is provided to staff involved in supervision and } \\
\text { inspection. } \\
\text { The Act on Prevention of Transfer of Criminal Proceeds stipulates requirements with } \\
\text { which financial institutions (including insurers) and other entities must comply. The } \\
\text { Supervisory Guideline expands on these requirements, while the industry } \\
\text { associations-in response to a request by the FSA-have provided additional } \\
\text { implementation guidance. } \\
\text { The FSA provides feedback to insurers in response to its off-site reviews and onsite } \\
\text { inspections. Where necessary, the FSA requires insurers to submit additional reports } \\
\text { and improve their business operations. } \\
\text { The FSA is cooperating with other Japanese authorities to implement measures } \\
\text { recommended by the "Third Mutual Evaluation," which was performed in } 2008 \text {. The law } \\
\text { has been revised and the FSA is working on revisions to the related Ordinance, which } \\
\text { will strengthen the requirements for identification of ultimate beneficiaries. } \\
\text { The FSA passes notifications on suspicious cases submitted by insurers to the Japan } \\
\text { Financial Intelligence Center, which investigates such cases. So far, there have been } \\
\text { no cases of suspected ML/FT in the insurance sector requiring the exchange of } \\
\text { information with foreign authorities. If such a case were to arise, the Japan Financial } \\
\text { Intelligence Center would be responsible for dealing with the foreign authorities. }\end{array}$ \\
\hline
\end{tabular}




\begin{tabular}{|c|c|}
\hline Assessment & Observed. \\
\hline Comments & $\begin{array}{l}\text { The AML/CFT efforts of insurers and intermediaries should be inspected regularly. The } \\
\text { FSA should reinforce its supervision of AML/CFT through more frequent onsite } \\
\text { inspections of insurers and intermediaries (see ICPs } 9 \text { and 18). }\end{array}$ \\
\hline ICP 23 & $\begin{array}{l}\text { Group-wide Supervision } \\
\text { The supervisor supervises insurers on a legal entity and group-wide basis. }\end{array}$ \\
\hline Description & $\begin{array}{l}\text { The FSA supervises insurers as legal entities and on a group-wide basis. This is } \\
\text { provided for by the regulatory framework, including a chapter of the IBA that deals with } \\
\text { insurance holding companies and a related Supervisory Guideline. } \\
\text { The scope of the group subject to group-wide supervision is largely defined by the IBA. } \\
\text { It includes insurers (including sister or subsidiary insurers), holding companies } \\
\text { (including intermediate holding companies), other regulated entities, non-regulated } \\
\text { entities, and special-purpose entities. The FSA has the flexibility to broaden the scope } \\
\text { of supervision, for example, to deal with a restructuring undertaken in an attempt to } \\
\text { avoid supervision. } \\
\text { If a group includes banks or securities firms, the respective FSA units supervise the } \\
\text { legal entities, with group-wide supervision being the responsibility of the FSA unit that } \\
\text { deals with the dominant sector. There is a separate Supervisory Guideline on financial } \\
\text { conglomerates. } \\
\text { The FSA monitors layers and cross-holdings within a group. If the FSA considers that } \\
\text { such structures might cause problems for an insurer, or lack sufficient transparency to } \\
\text { support supervision, it can take action and has done so in practice. } \\
\text { The group-wide supervision framework includes requirements related to group-wide } \\
\text { governance, risk management, and solvency. } \\
\text { Insurance holding companies are required to submit semi-annual reports on their } \\
\text { financial status and business activities. Additional information is obtained through } \\
\text { interviews, onsite inspections, and special requests. Insurance holding companies are } \\
\text { required to have systems in place to meet these information needs, and such systems } \\
\text { are reviewed by the FSA through onsite inspections. }\end{array}$ \\
\hline Assessment & Observed. \\
\hline Comments & $\begin{array}{l}\text { Group-wide solvency requirements have been adopted, which insurance holding } \\
\text { companies must meet by March } 2012 \text { (the end of the fiscal year). }\end{array}$ \\
\hline ICP 24 & $\begin{array}{l}\text { Macroprudential Surveillance and Insurance Supervision } \\
\text { The supervisor identifies, monitors and analyses market and financial developments } \\
\text { and other environmental factors that may impact insurers and insurance markets and } \\
\text { uses this information in the supervision of individual insurers. Such tasks should, } \\
\text { where appropriate, utilize information from, and insights gained by, other national } \\
\text { authorities. }\end{array}$ \\
\hline
\end{tabular}




\begin{tabular}{|c|c|}
\hline Description & $\begin{array}{l}\text { The FSA uses a variety of tools as part of its macroprudential surveillance. They } \\
\text { include the following: } \\
\text { - It has a unit responsible for market analysis, which prepares a weekly report } \\
\text { on local and international market developments, including quantitative } \\
\text { information. The supervisors review the report and consider the effects of } \\
\text { these developments on insurers. } \\
\text { - The insurance risk unit prepares quarterly analyses of insurance market } \\
\text { issues, which are discussed by senior management of the FSA. The analyses } \\
\text { are also circulated widely within the FSA. } \\
\text { - Senior management of the major insurers is interviewed annually for the views } \\
\text { on industry risks and trends. The results are fed back to industry. } \\
\text { - Supervisory financial information is analyzed by insurer, insurance group, and } \\
\text { across the industry. The information analyzed includes solvency margins, } \\
\text { reinsurance exposures, and credit exposures. } \\
\text { The FSA performs top-down stress testing of the insurance sector each } \\
\text { quarter and as necessary with respect to equity-price, exchange-rate, and } \\
\text { credit risks. } \\
\text { Action is taken with individual insurers in response to concerns that are identified. } \\
\text { Senior management of the FSA periodically discusses the results of the surveillance } \\
\text { and considers whether additional supervisory measures are needed to deal with } \\
\text { macroprudential concerns. } \\
\text { The FSA comments publicly on market developments, trends, and its outlook. } \\
\text { However, it does not make market data publicly available. } \\
\text { Insurers are expected to perform stress tests and they generally submit the results of } \\
\text { such tests to the FSA. However, the FSA does not prescribe specific stress scenarios } \\
\text { that insurers are required to test. } \\
\text { Although the FSA generally focuses its attention on the largest insurers when } \\
\text { considering macroprudential issues, it has neither established a process to assess the } \\
\text { potential systemic importance of insurers nor identified specific supervisory responses } \\
\text { to deal with systemically-important insurers. }\end{array}$ \\
\hline Assessment & Partly observed. \\
\hline Comments & $\begin{array}{l}\text { The IAIS and other international organizations are currently considering how to define } \\
\text { and deal with global systemically-important financial institutions. Such considerations } \\
\text { are quite relevant to Japan, in light of the size and concentration of its insurance } \\
\text { sector. The FSA should not only remain actively engaged in the international } \\
\text { discussions, but also deal with the issue for its own market. } \\
\text { Some steps should be taken to enhance the macroprudential value of the information } \\
\text { currently being prepared by the FSA. The FSA should develop a comprehensive } \\
\text { process for bringing together the various pieces of information, identifying issues of } \\
\text { possible macroprudential importance to the insurance sector (and the financial sector } \\
\text { more broadly), formulating adverse scenarios for further consideration, and } \\
\text { communicating the results of this analysis internally and with other Japanese } \\
\text { supervisory authorities. The effects of the adverse scenarios should be assessed }\end{array}$ \\
\hline
\end{tabular}




\begin{tabular}{|c|c|}
\hline & $\begin{array}{l}\text { quantitatively, through either top-down stress testing by the FSA or bottom-up stress } \\
\text { testing of prescribed scenarios by the insurers. } \\
\text { The FSA should also contribute to the ability of others to analyze the industry by } \\
\text { making market data publicly available. }\end{array}$ \\
\hline ICP 25 & $\begin{array}{l}\text { Supervisory Cooperation and Coordination } \\
\text { The supervisor cooperates and coordinates with other relevant supervisors and } \\
\text { authorities subject to confidentiality requirements. }\end{array}$ \\
\hline Description & $\begin{array}{l}\text { The LEFSA empowers the FSA to cooperate with other supervisors and authorities, } \\
\text { both local and foreign. The FSA cooperates with other local authorities, such as the } \\
\text { BOJ, the Financial Investigations Unit, and the ministries responsible for supervising } \\
\text { cooperative insurers, without written agreements. } \\
\text { In some cases, the FSA deals with foreign supervisors on the basis of written } \\
\text { agreements that specify the procedures for cooperation and coordination. The FSA is } \\
\text { a signatory to the IAIS Multilateral Memorandum of Understanding. It also has bilateral } \\
\text { agreements with the supervisors in foreign jurisdictions where Japanese insurers have } \\
\text { material operations. The FSA participates in colleges of supervisors for foreign } \\
\text { insurers that operate in Japan. } \\
\text { In other cases, the FSA cooperates with foreign supervisors on an ad hoc basis. The } \\
\text { FSA serves as the group-wide supervisor of Japanese insurers and is currently } \\
\text { considering the establishment of supervisory colleges for those with material foreign } \\
\text { operations, although its efforts were delayed by the need to give priority to dealing with } \\
\text { the effects of the Great East Japan Earthquake. The FSA communicates regularly with } \\
\text { both Japanese insurers and foreign insurers that operate in Japan to understand the } \\
\text { structure and operations of their groups. } \\
\text { The FSA has offices in London, New York, and Singapore, which are involved in } \\
\text { inspections and help to facilitate communication with other supervisors. }\end{array}$ \\
\hline Assessment & Largely observed. \\
\hline Comments & $\begin{array}{l}\text { The FSA serves as the group-wide supervisor of Japanese insurance groups, but in } \\
\text { some cases does not regularly communicate with foreign host supervisors. } \\
\text { The FSA should establish supervisory colleges for Japanese insurers with material } \\
\text { foreign operations, supported by adequate staff and financial resources, and use the } \\
\text { colleges to enhance cooperation and coordination. }\end{array}$ \\
\hline ICP 26 & $\begin{array}{l}\text { Cross-Border Cooperation and Coordination on Crisis Management } \\
\text { The supervisor cooperates and coordinates with other relevant supervisors and } \\
\text { authorities such that a cross-border crisis involving a specific insurer can be managed } \\
\text { effectively. }\end{array}$ \\
\hline Description & $\begin{array}{l}\text { As noted under ICPs } 3,23 \text {, and } 25 \text {, the FSA exchanges information, cooperates, and } \\
\text { coordinates with other supervisors in various contexts. } \\
\text { The FSA has not yet developed comprehensive plans for dealing with Japanese } \\
\text { insurers in crisis, but it has participated in the development of such plans for some }\end{array}$ \\
\hline
\end{tabular}




\begin{tabular}{|l|l|}
\hline $\begin{array}{l}\text { foreign insurers that operate in Japan. } \\
\text { Insurers are required to have the systems needed to supply information to the FSA, } \\
\text { including information related to actual or potential crises. In the past, they have been } \\
\text { able to comply with any requests for information. } \\
\text { The FSA has the authority to cooperate in the development of internationally- } \\
\text { coordinated solutions to actual or potential crises. } \\
\text { Insurers are encouraged to prepare business continuity plans, which are reviewed by } \\
\text { the FSA. Most insurers-including all of the larger insurers with foreign operations- } \\
\text { have done so, and the plans worked well in the aftermath of the 2011 earthquakes and } \\
\text { tsunami. In that situation, the FSA itself communicated with the public at various times. } \\
\text { The FSA has responded to requests from foreign supervisors for information about the } \\
\text { effects of local and regional natural catastrophes on Japanese insurers. }\end{array}$ \\
\hline Assessment & $\begin{array}{l}\text { Partly observed. } \\
\text { Comments }\end{array}$ \\
$\begin{array}{l}\text { Cross-border cooperation and coordination specifically related to crisis management of } \\
\text { Japanese insurers is in its initial stages. } \\
\text { The FSA should develop comprehensive plans for dealing with insurers in crisis and } \\
\text { ensure that it has the tools needed to carry out such plans. It should ensure that the } \\
\text { plans are internationally-coordinated by working with foreign supervisors, for example, } \\
\text { through supervisory colleges. } \\
\text { Insurers should be required to prepare contingency plans, which should include } \\
\text { specific procedures for use in a gone-concern situation. }\end{array}$ \\
\hline
\end{tabular}

